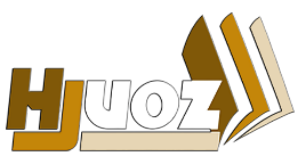

hjuoz.uoz.edu.krd
كوَقارا زانستيّن مروّقايهتى يا زانكوَيا زاخوّ

مجلة العلوم الانسانية لجامعة زاخدو

Humanities Journal of University of Zakho (HJUOZ)

Vol. 8, No. 2, pp. 242-265, Jun -2020

$$
\begin{aligned}
& \text { دور التعليم المحاسبي المستمر في تعزيز جودة الأداء المحاسبي }
\end{aligned}
$$

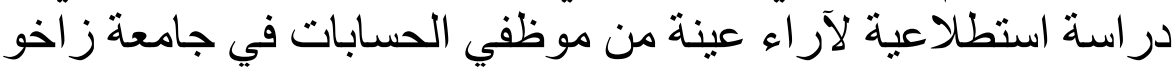

$$
\begin{aligned}
& \text { كوثان محي الدين علي كودان" و إيمان عبد الكريم قاسم العبادي } \\
& \text { قسم العلوم المالية والمصرفية، كلية الادارة والاقتصاد، جامعة زاخو، إقليم كردستان - العر اق. }
\end{aligned}
$$

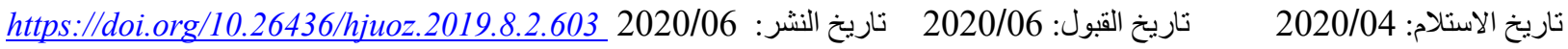

الملخص:

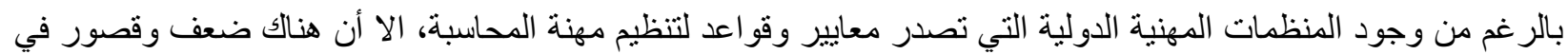

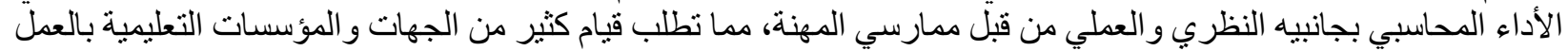

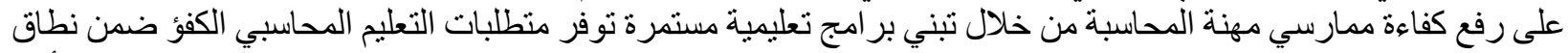

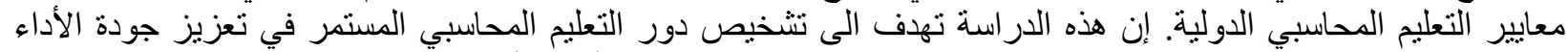

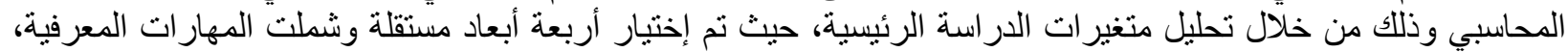

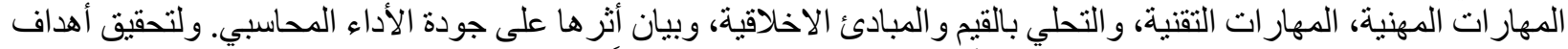

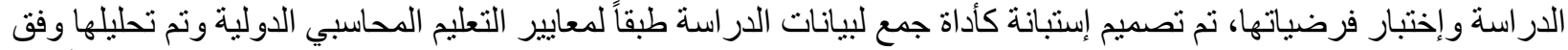

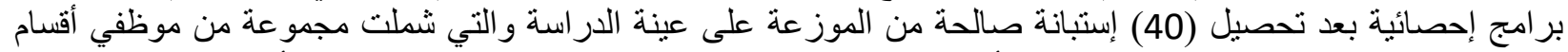

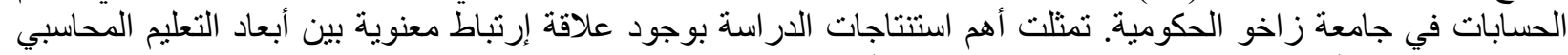

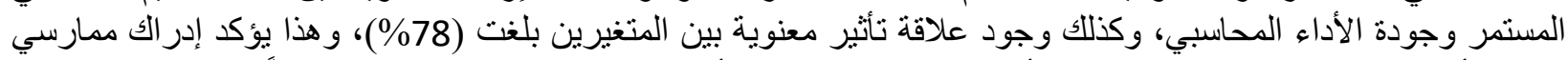

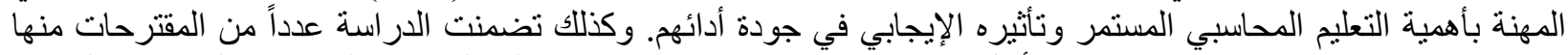

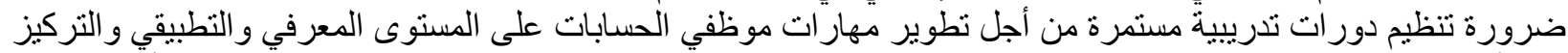

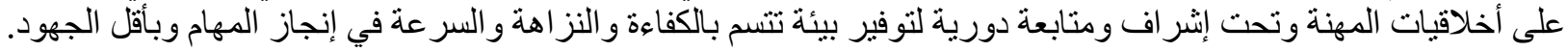
الكلمات الدالة: التعليم المحاسبي، التعليم المحاسبي المستمر ، معايير التعليم المحاسبي الدولية، جودة الاداء الدئية المحاسبي.

محاسبين مؤهلين بالمهار ات العلمية والعملية التي تفتح لهم آفاق علم ممارسة المهنة. يمكن القول بأن معايير التعليم الدولية للمحاسبين المهنيين تمثنل

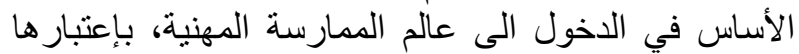

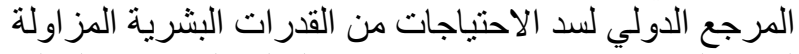

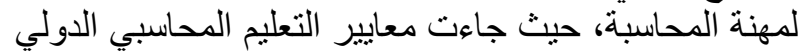

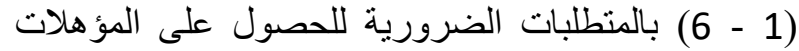

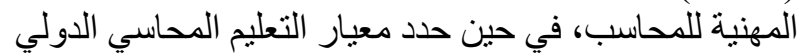

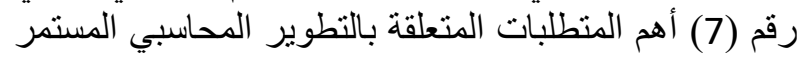

للمهنة.

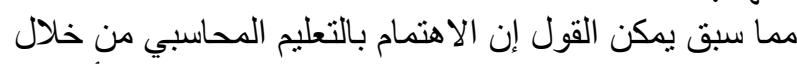

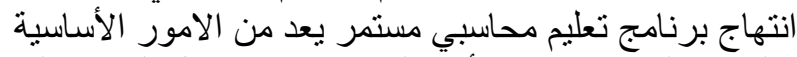

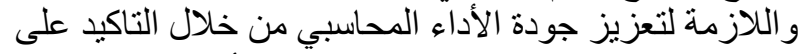

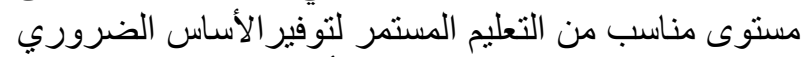

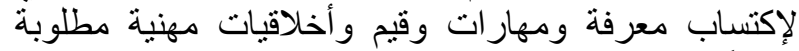

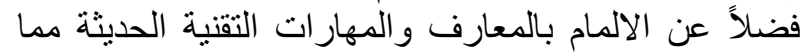

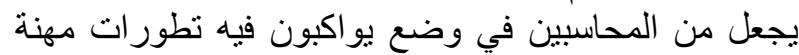

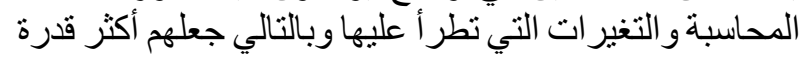
في التعامل و الإلمام بمقتضيات ممارسة هذه المهار المهنة.

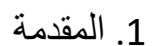

تؤدي مهنة المحاسبة دوراً محورياً كونها تمثل لغة لغة المال

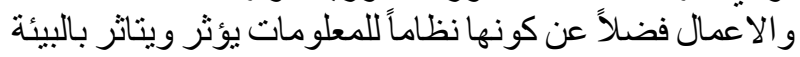

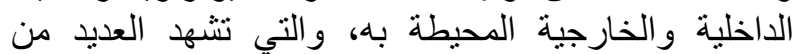

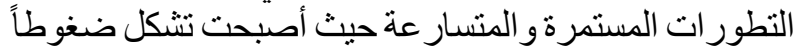

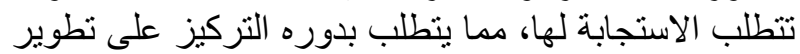
قدرات ومؤهلات المحاسبين الامر الذي ينعكس على تلى تعزيز جودة أدائهم المحاسبي.

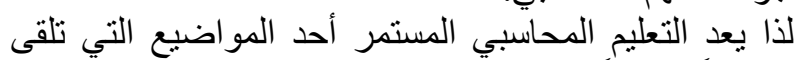

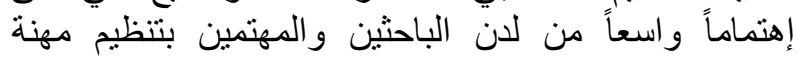
المحاسبة سواء أكان ذللك الاهتمام على الباحنين والمهنوى الداخلي أم

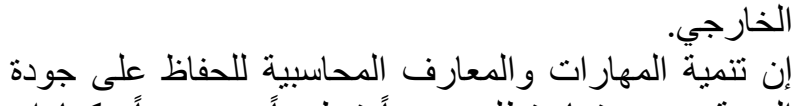

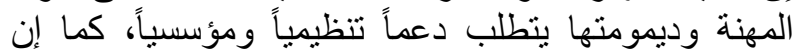

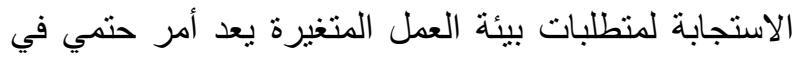

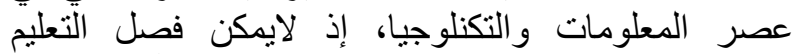

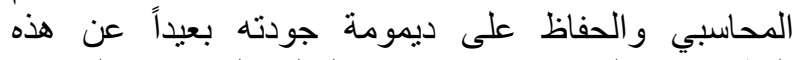

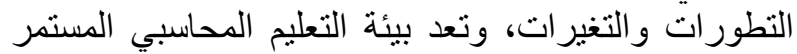

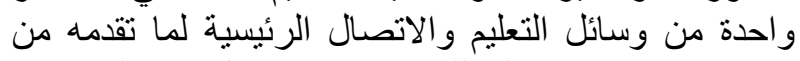

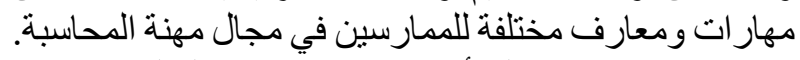
هذا ولابد من الاشارة الى أهمية دور مؤسسات التعليم في إعداد 
الفرضية الثالثة: توجد علاقة تأثثر ذات دلالة معنوية

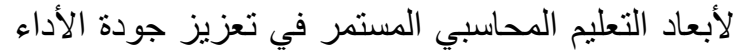
المحاسبي. لتحقيق غرض البحث و الوصول الى أهدافه المحددة فقد اعتمد البحد

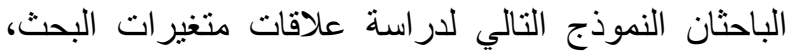
ويوضح الثكل التالي هذه العلاقات:

$$
\text { الشكل(1): أنموذج البحث }
$$

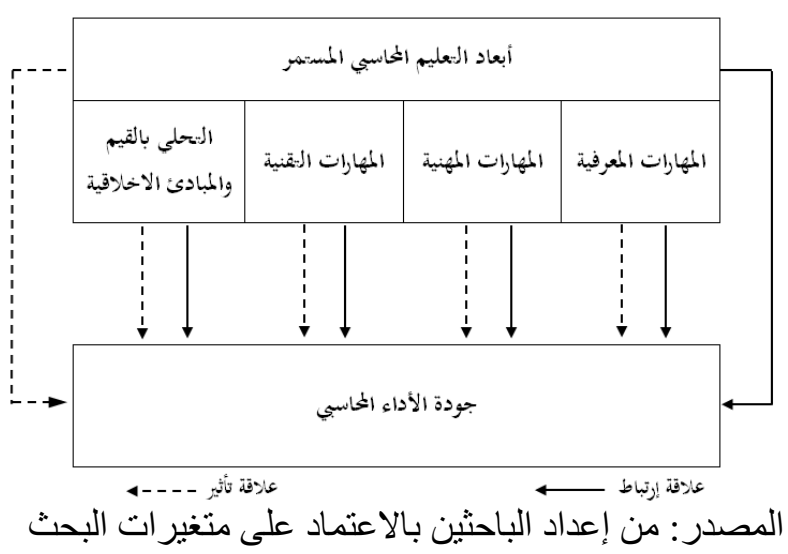

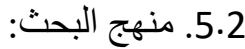

إعتمد الباحثان على المنهج الوصفي في كتابة الجانب النظري

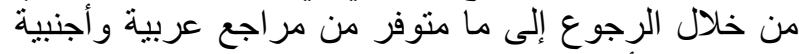

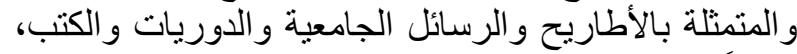

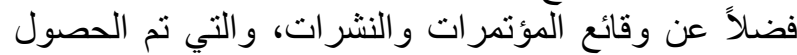

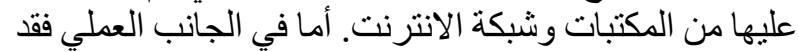

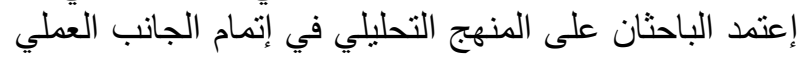

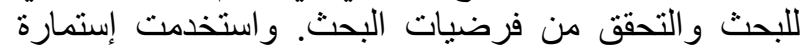

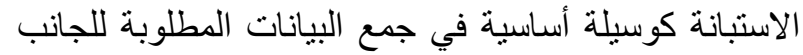

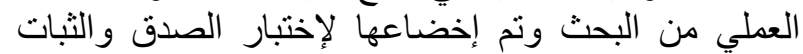

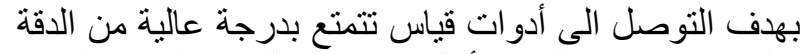

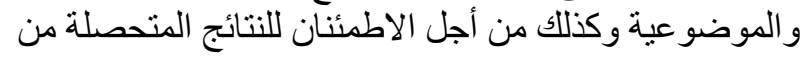
الادوات المطبقة في التحليل. ففي هذه الدراسة تم قياس الميلف المصداقية عن طريق الاتساق

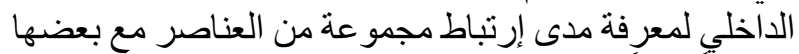

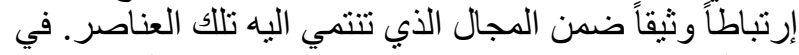

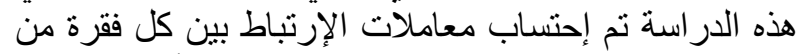
فقرات الإستبانة عن طريق إستخدام معامل ألفا كرونباخ باستخدام البرنامج الاحصائي (Cronbach's Alpha)

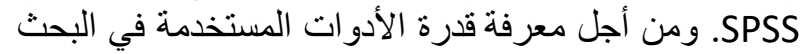

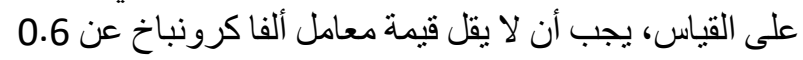

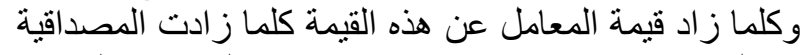

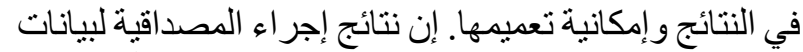

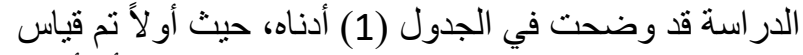

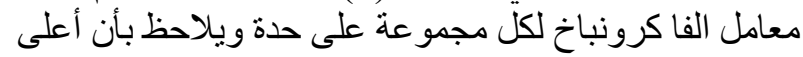

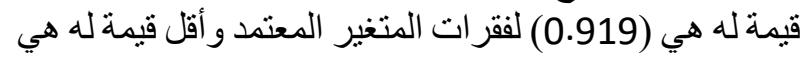

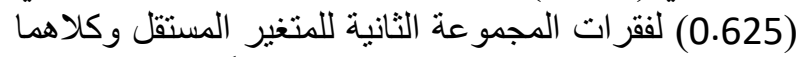

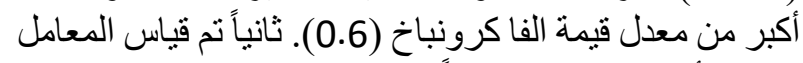

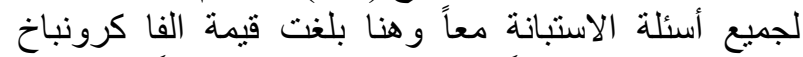
(0.933) وهي أيضاً أكبر من (0.6). وأخيراً نم إجراء ألغاء

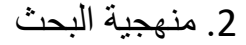

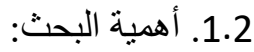

تأتي أهمية البحث من خلال الآل الآتي:

1. بيان دور التعليم المحاسبي المستينمر في تعزيز الأداء

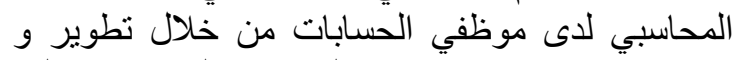

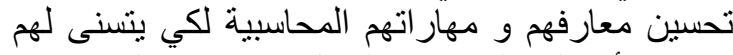

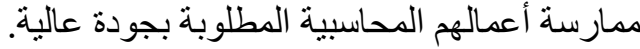

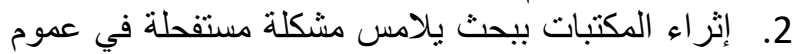

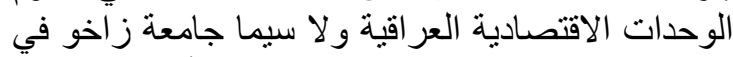

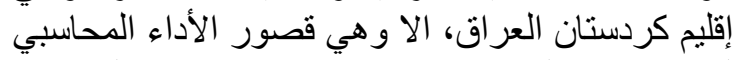

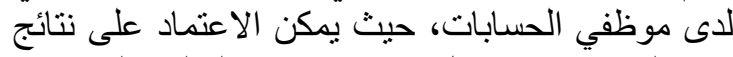

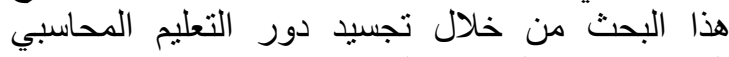

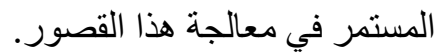

2.2 - 2. - 2 مشكلة البحث:

على الرغم من التوسع الكبير الذي شهيته البيئة المحلية

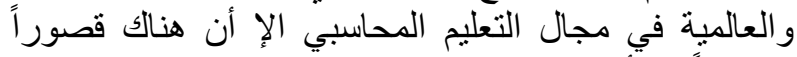

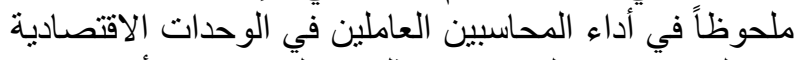

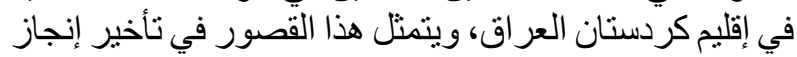

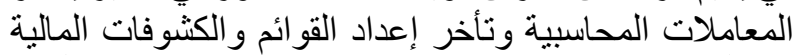

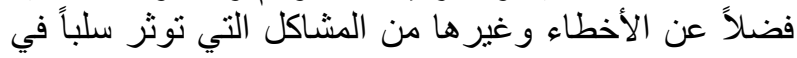

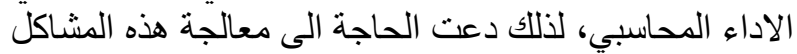

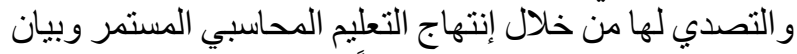

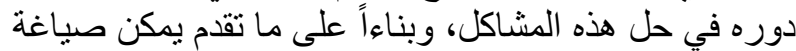

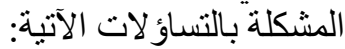

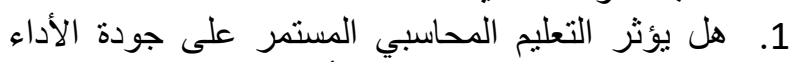

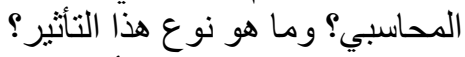

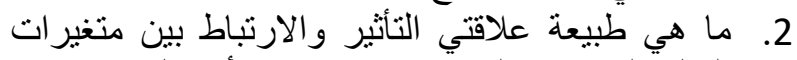

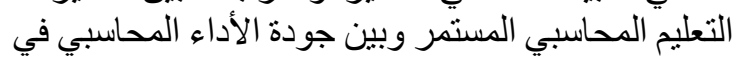
عينة البحث؟ وما هو نوع هذه العلاقة؟

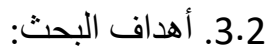
يرهد البحث الى تحقيق الاهداف الاتية:

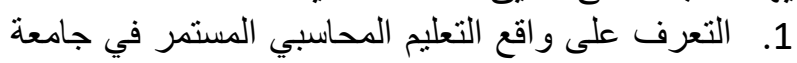
زاخو من وجهة نظر موظفي الحسابات من العأملين في التئي

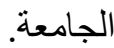
2. التعريف بالتعليم المحاسبي المستمر وبيان أهم مجالاته في

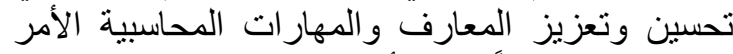
الذي ينعكس ايجاباً على الأداء المحاسبي.

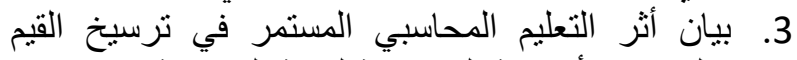

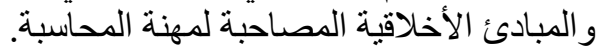

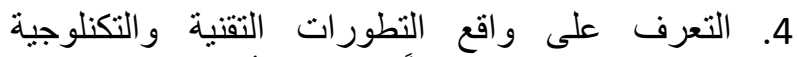

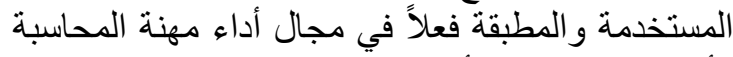
و أثر ها على جودة الأداء المحاسبي. 4.2 - أنموذج البحث وفرضياته:

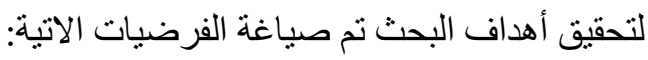

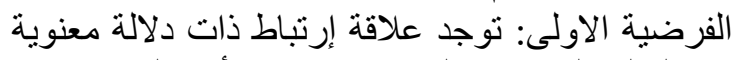

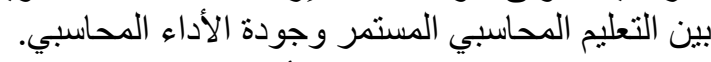

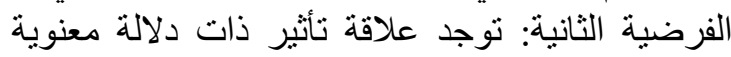
للتعليم المحاسبي المستمر في جودة الأداء المحاسبي. 
2. معامل الارتباط البسيط: لتحديد طبيعة علاقة الارتباط بين

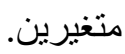
3. معامل الانحدار المتعدد: يستخدم هذا الأسلوب في تحديد تأثثير المتغير المستقل في المتغير المعتمد. 4. - إستخدام اختبار (F): لتعديد العلاقة التنأثيرية بين متغيري البحث.

8.2 8.2 مجتمع البحث و عينته:

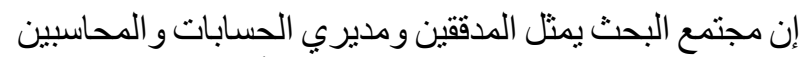

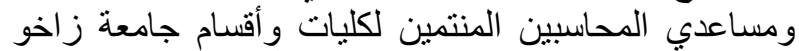

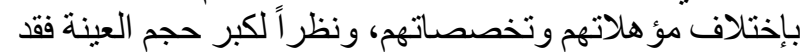

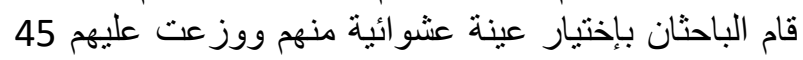

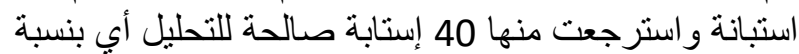

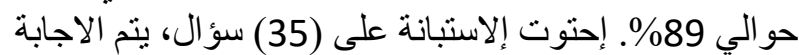

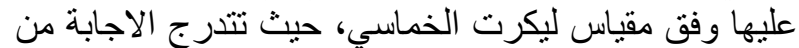

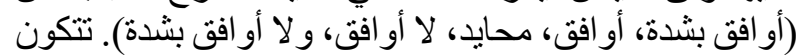

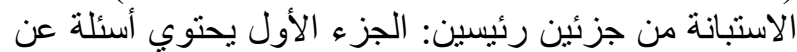

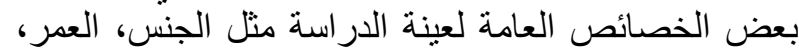

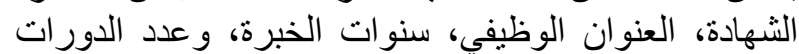

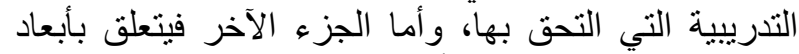

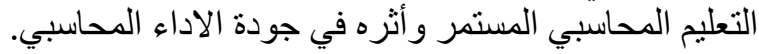

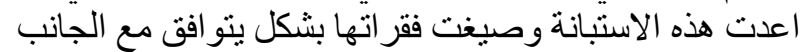

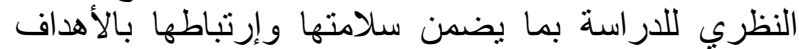

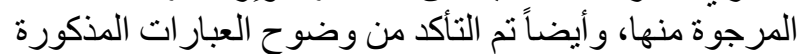

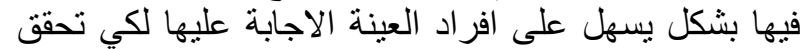

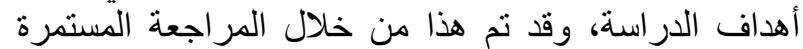

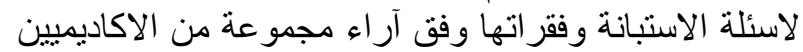

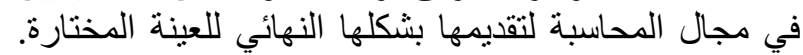

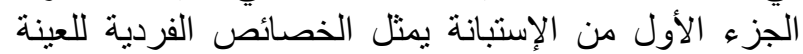

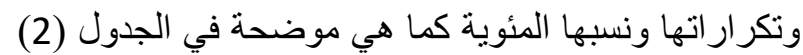

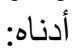

الاختبار على أساس المجاميع الخمسة لأسئلة المتغيرين

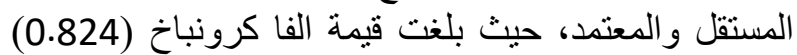

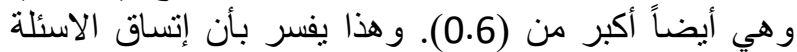

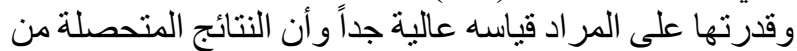

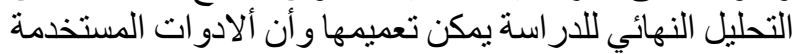

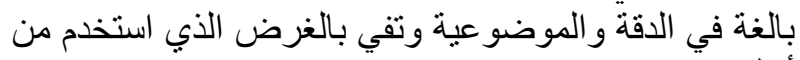

جدول رقم (1): إختبار الصدق و الثبات لاستبانة البحث

المصدر : من إعداد الباحين بالآعتماد على نتائج

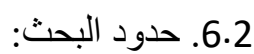
الحدود الزمانية: تضمنت الحدود البحثية الزمانية تحديداً من 2019/11/26 - 2018/9/1

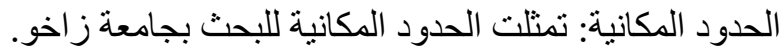
الحدود البشرية: تم إختيار عينة عشو ائية من موظفي ومدية لئيري الحسابات في جامعة زاخو.

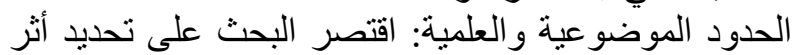

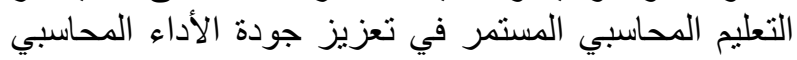

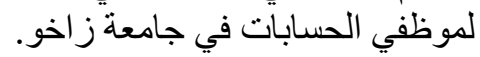
7.2. أساليب التحليل الاحصائي:

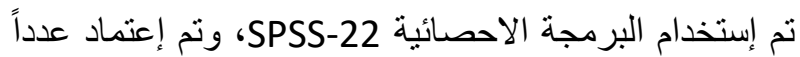

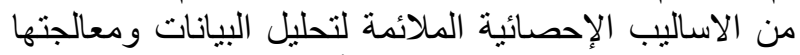

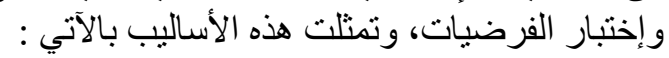

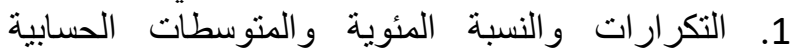

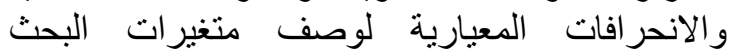

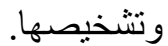
جدول رقم (2): الخصائص الفردية لعينة البحث

\begin{tabular}{|c|c|c|c|}
\hline النسبة المئوية & التكر ار & & المتغير ات \\
\hline 57.5 & 23 & الذكور & \multirow{3}{*}{ الجنس } \\
\hline 42.5 & 17 & الاناث & \\
\hline 100.0 & 40 & المجموع & \\
\hline 7.5 & 3 & 25 فأقلّ & \multirow{6}{*}{ الفئات العمرية } \\
\hline 80.0 & 32 & $35-26$ & \\
\hline 12.5 & 5 & $45-36$ & \\
\hline 0 & 0 & $55-46$ & \\
\hline 0 & 0 & $65-56$ & \\
\hline 100.0 & 40 & المجموع & \\
\hline 2.5 & 3 & إعدادية فما دون & \multirow{6}{*}{ المستوى التعليمي } \\
\hline 35.0 & 14 & دبلوم (سنتان) & \\
\hline 55.0 & 22 & بكالوريوس & \\
\hline 0 & 0 & دبلوم عالي & \\
\hline 2.5 & 1 & ماجستير & \\
\hline 0 & 0 & دكتوراه & \\
\hline
\end{tabular}




\begin{tabular}{|c|c|c|c|}
\hline 100.0 & 40 & المجموع & \\
\hline 22.5 & 9 & مساعد محاسب & \multirow{6}{*}{ العنوان الوظيفي } \\
\hline 42.5 & 17 & محاسب & \\
\hline 7.5 & 3 & مدير حسابات & \\
\hline 25.0 & 10 & مدقق & \\
\hline 2.5 & 1 & أخرى & \\
\hline 100.0 & 40 & المجموع & \\
\hline 30.0 & 12 & 5 سنوات فأقل & \multirow{6}{*}{ سنوات الخبرة } \\
\hline 57.5 & 23 & $10-6$ & \\
\hline 10.0 & 4 & $15-11$ & \\
\hline 2.5 & 1 & $20-16$ & \\
\hline 0 & 0 & 21 - فأكثر & \\
\hline 100.0 & 40 & المجموع & \\
\hline 15.0 & 6 & $3-1$ & \multirow{6}{*}{ عدد الدورات التدريبية } \\
\hline 5.0 & 2 & $6-4$ & \\
\hline 0 & 0 & $9-7$ & \\
\hline 0 & 0 & 9 - فأكثر & \\
\hline 80.0 & 32 & لم التحق بدورة & \\
\hline 100.0 & 40 & المجموع & \\
\hline
\end{tabular}

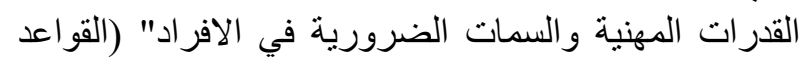

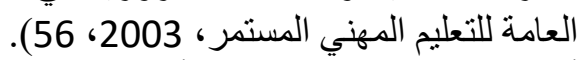

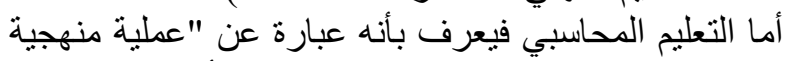

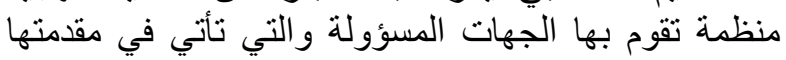

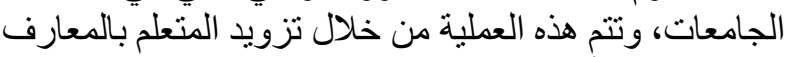

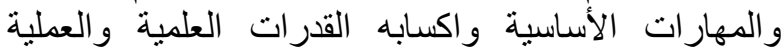

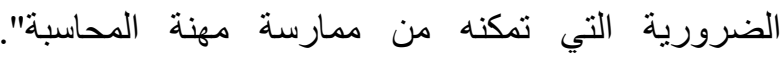
(بو عزرية، 2017: 7 (الفرورية )

يتضح من هذا التعريف إن التعليم المحاسبي يتكون من شقين الإدين

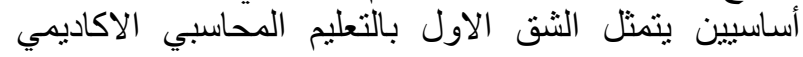

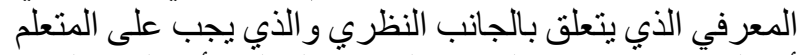

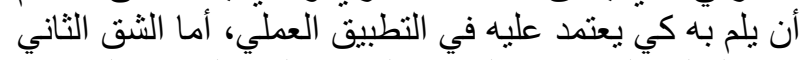

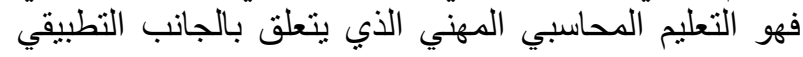

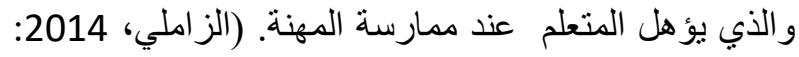
291) وفي بحثنا سيتم التركيز على الثقى الثاني منه.

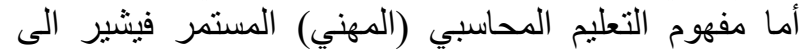

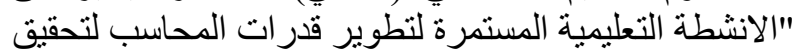

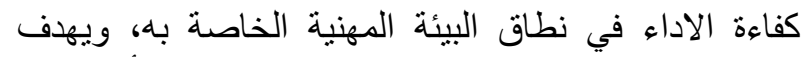
التطوير المهني الى تعزيز الكفاءة المهنية للمحاسب المهاء أو الحفاظ عليها بعد التأهيل". (النعيمي، 2016: التعزيز الكفاعة 191 ).

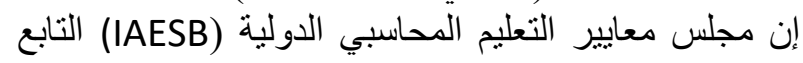

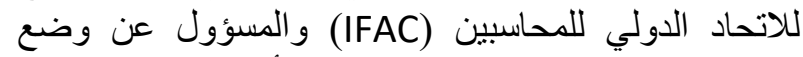
المعايير الخاصنة بالتعليم المحاسبي فقد أورد التعريف الاتي التئي

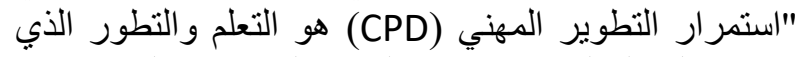

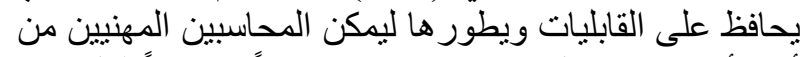

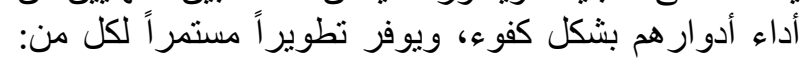

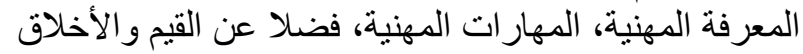

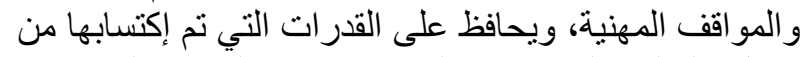

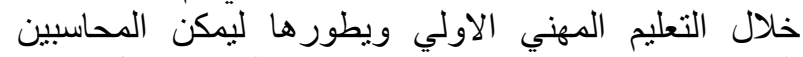

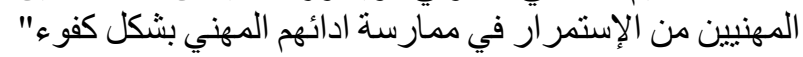

.(IAESB, 2014:14, 21)
ويوضح الجدول أعلاه بأن نسبة الذكور من العينة هي (5.57\%)

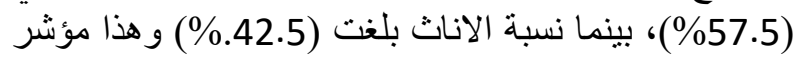

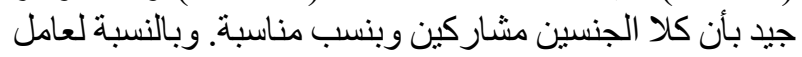

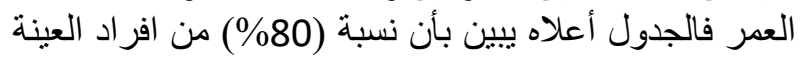

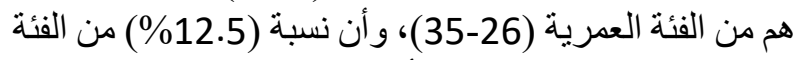
العمرية (36-45) في حين أن فقط (75.5\%) (75) هم من الفئة

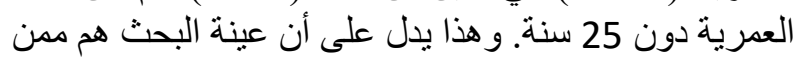

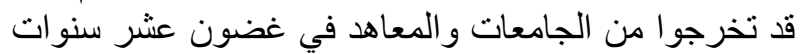

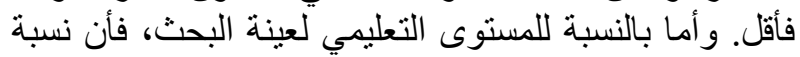

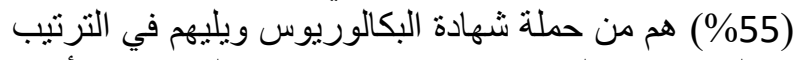

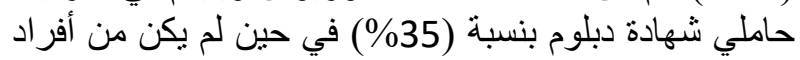

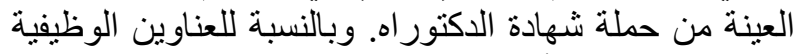

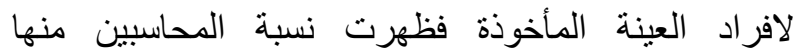

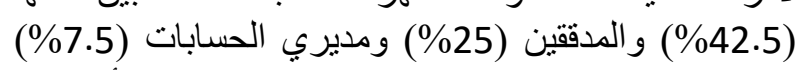

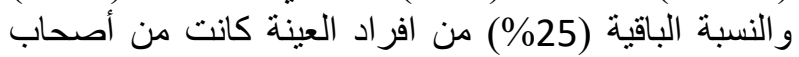

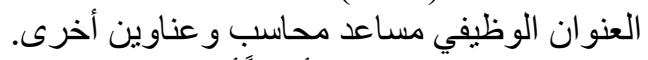

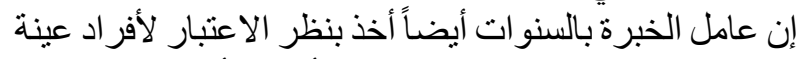

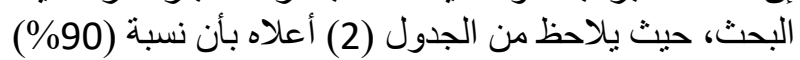

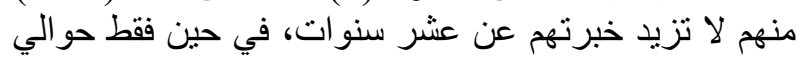

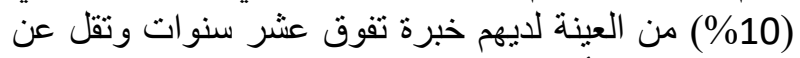

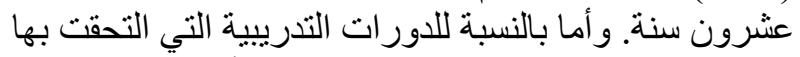

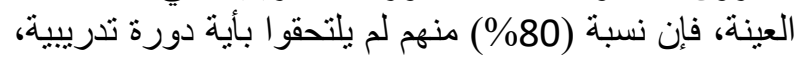
بينما نسبة المشاركة فقط بلغت (20\%).

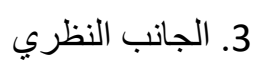

1.3. التعليم المحاسبي المستمر:

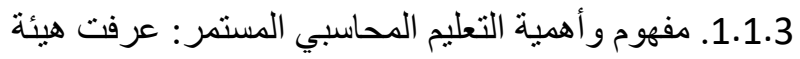

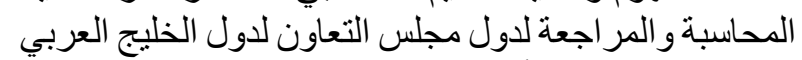

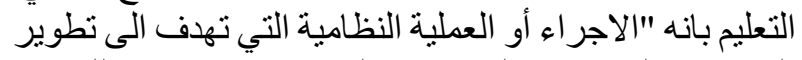

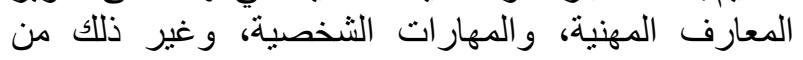


7. يعتبر أحد المتطلبات الضرورية التي تؤكد جودة الاداء

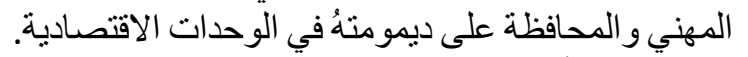

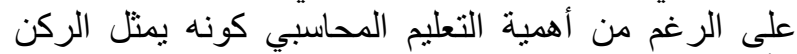

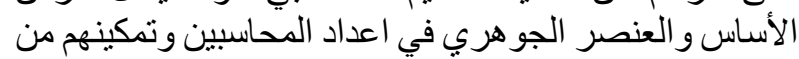

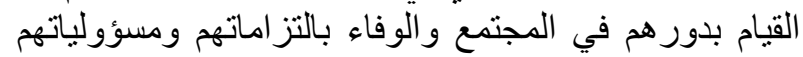

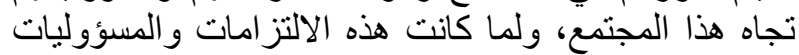

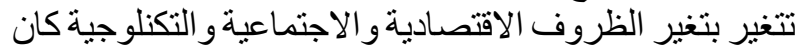

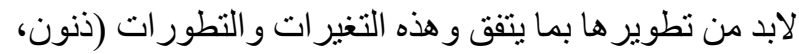

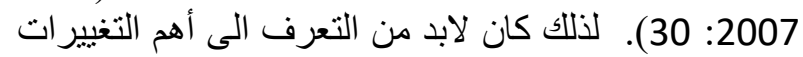

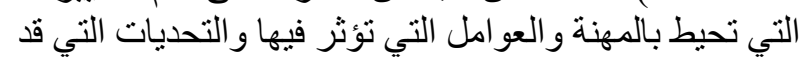

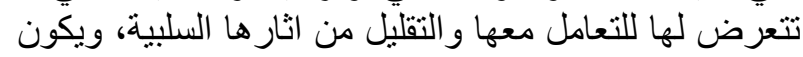
ذللك من خلال التخطيط الفعال لإعداد كو ادر محاسبية مهنية

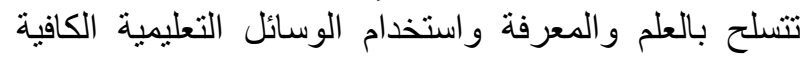

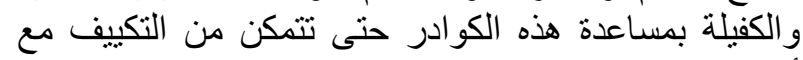
أوضاع السوق العالمية المنقدمة والكناء المنطورة (ذنون، 2007:

ومن أهم التحديات التي تواجه مهنة المحاسبة: (الطويل

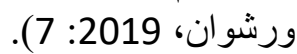

1. النقص الحاد في عدد المحاسبين المؤهلين تأهيلاً مهنياً

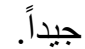

2. التغيرات و التحولات الجوهرية التي طر أت على مهنة

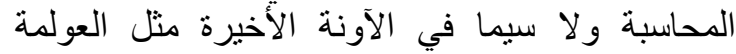

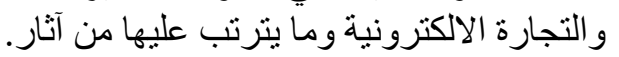

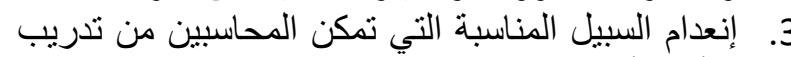

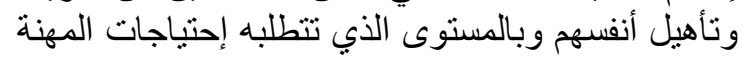

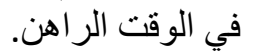

غباب أصول محاسبية مكتوبة ومتعارف علئ اليها يتم

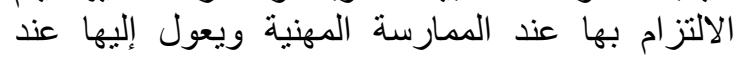

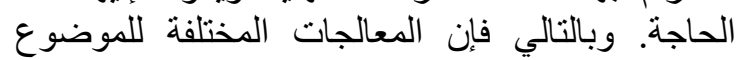

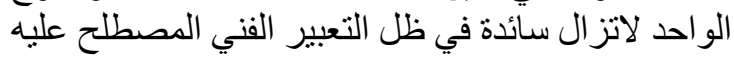

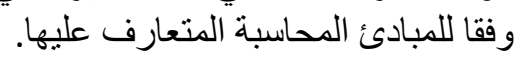

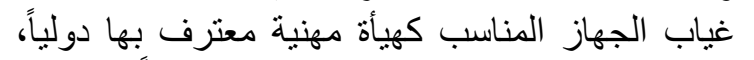

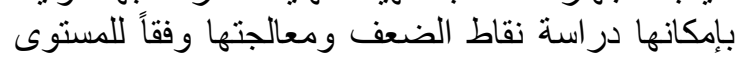

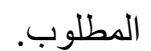

6. إطغاء الجانب الاكاديمي في المحاسبة والقصور في

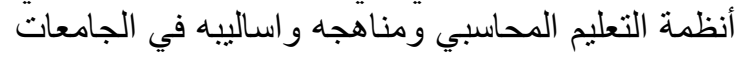

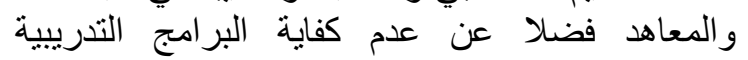
والتطبيقات العملية للمتخصصين في المحاسبة (ذنون، 2007:

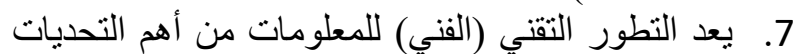

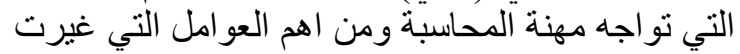

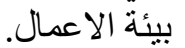

ولكي تستطيع مهنة المحاسبة مواجهة هذه التهائة التحديات

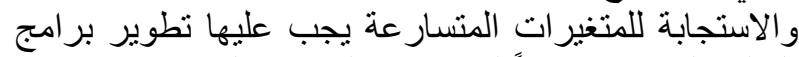

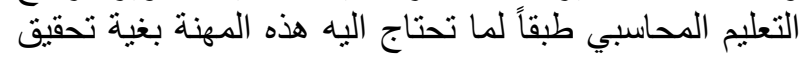

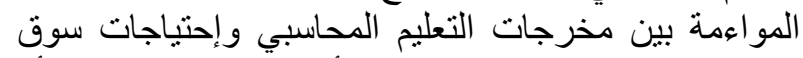

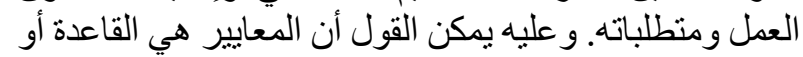

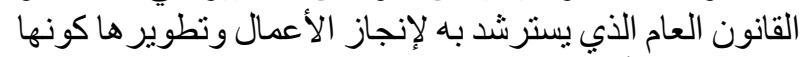

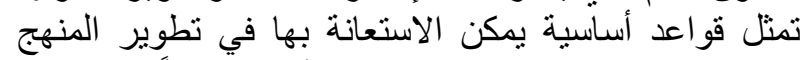

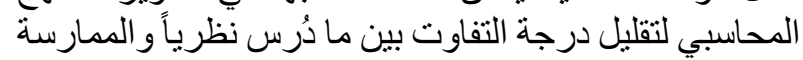

وترى (Kaspina, 2015:550) أن التعليم المحاسبي المستمر النقائي

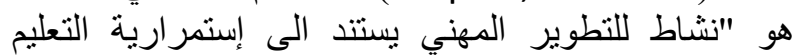

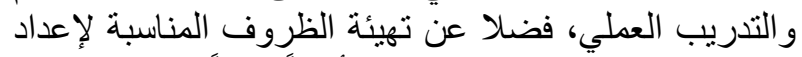

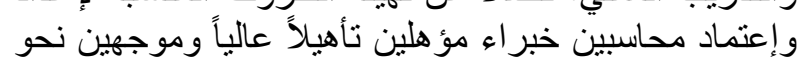

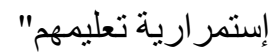

مما تقدم يرى الباحثان أن التعليم المحاسبي المستمر ما هو الا توني

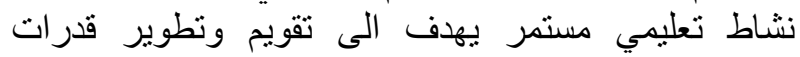
ومهارات المحاسبين المهنيين و المحافظة عليهي ونطا وتحديثها باستمر ار بما يمكنهم من العمل بكفاءة داخل بين بئاتهم المهنية.

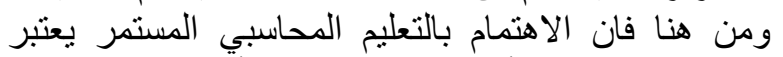

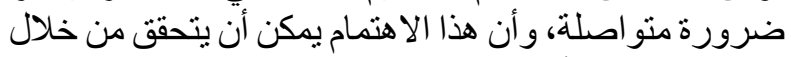

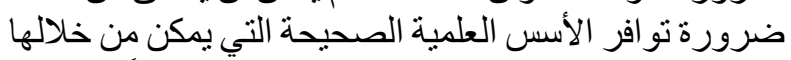

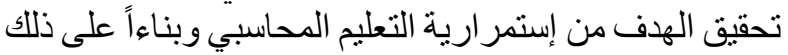

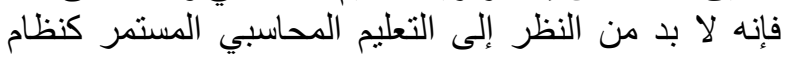

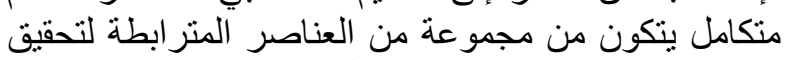

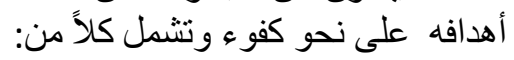

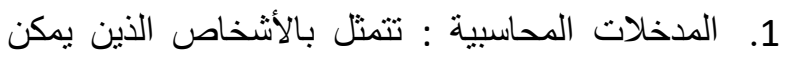

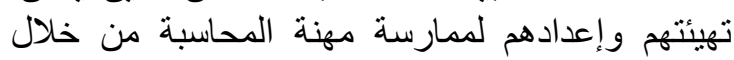
مختلف التطبيقات المحاسيبة. 2. العمليات التشغيلية :المتمثلة بوسئلة التهائل التعليم التي يمكن إستخدامها للتزود بمختلف المهار ات المحاسبية.

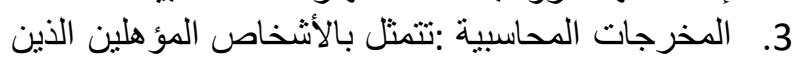

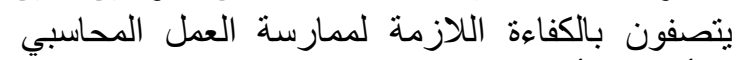

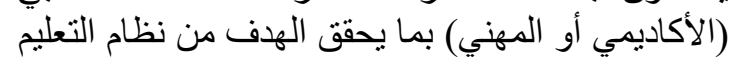

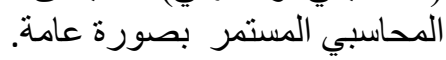

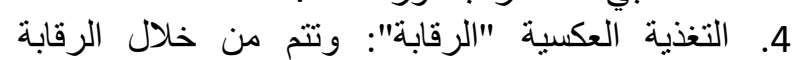

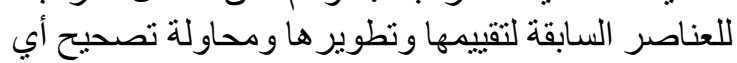

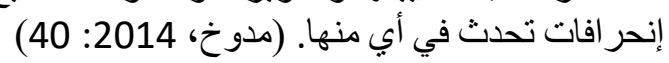
أما أهمية التعليم المحاسبي المستمر فتكمن في الاتي: (حمد، ( 2017: 23

1. إنه يوفر أساس ضروري من المعرفة المهنية و المهار ات

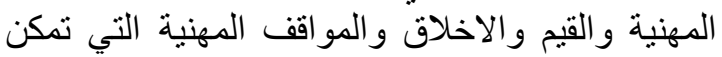

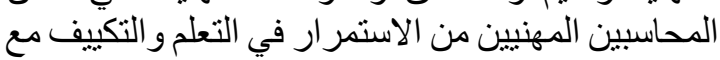
التغيير طو ال حياتهم المهنية.

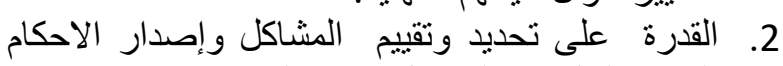

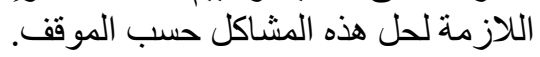

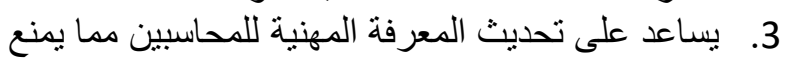

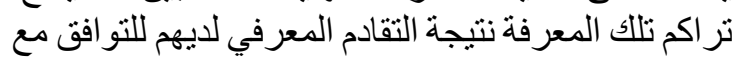

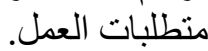
4. يلعب دور اً مهماً في الحفاظ على الكفاءة المهنية، وتحسين المهين

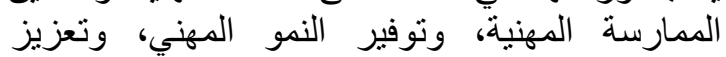
التفاعلات المهنية المطلوبة.

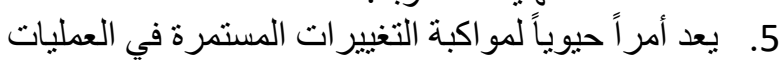

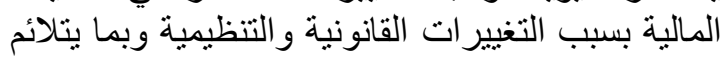

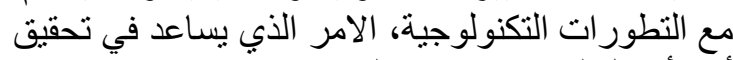

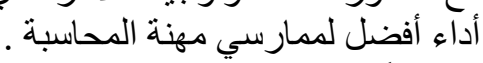

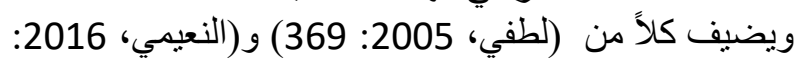

6. توفير تأكيداً معقولاً للمجتمع وعلى مستوى واسع بأن

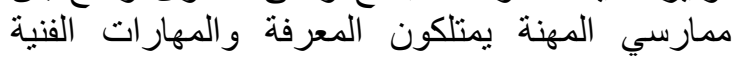
اللازمة لأداء الخدمات التي يقدمونها. 


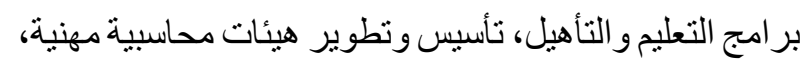

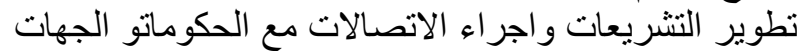

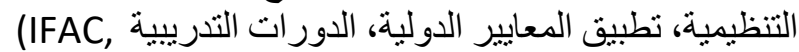

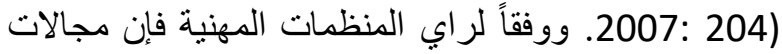

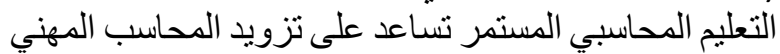

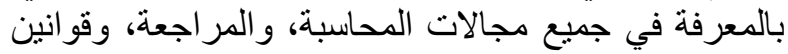

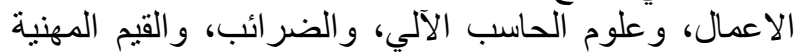

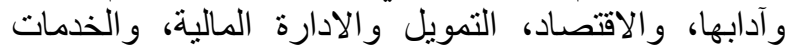
الاستشارية، والإحصاء، و الرياضيات (NSBA, 2011:2).

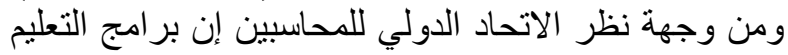

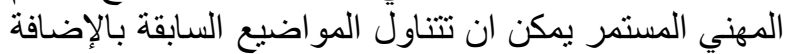

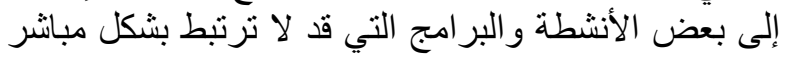

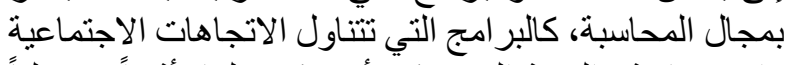

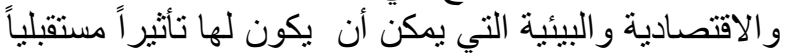

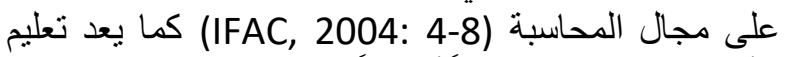
الأخلاقيات المهنية مطلباً أساسياً ضمن برائ الأج التعليم المهني

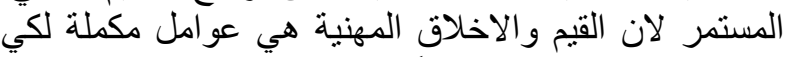

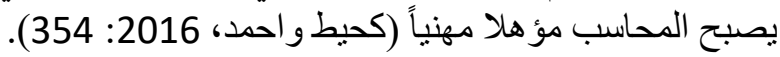

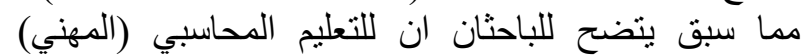

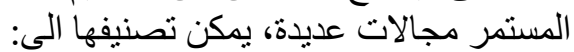

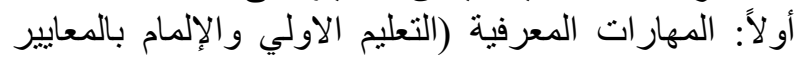

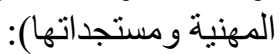

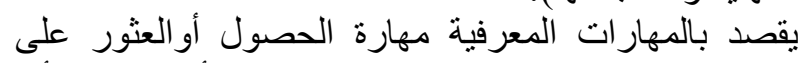

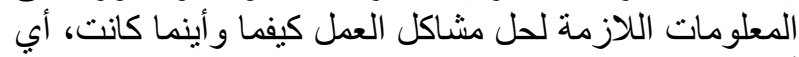

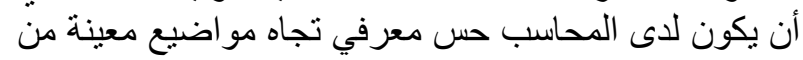

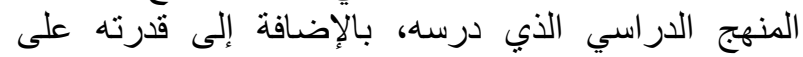

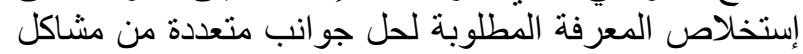

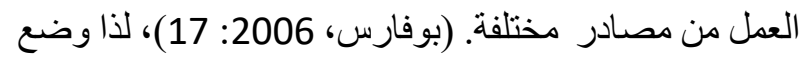

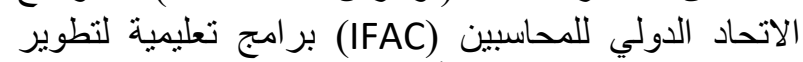

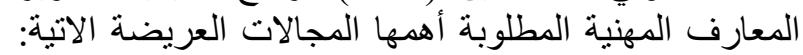

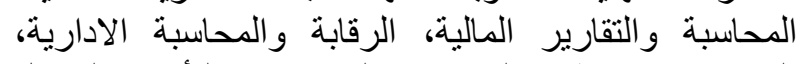

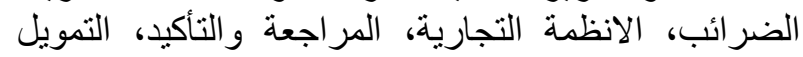

والادارة المالية (IFAC, 2007: 117). إن التعليم المحاسبي المستمر (المهني) الذي يمنح المعارئ المعرفة

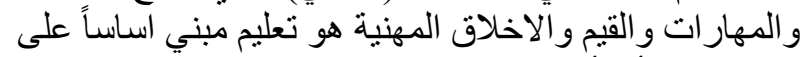

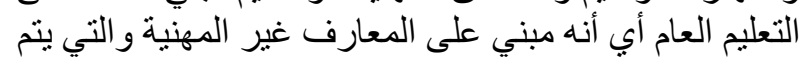

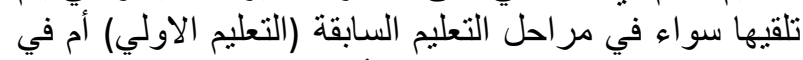

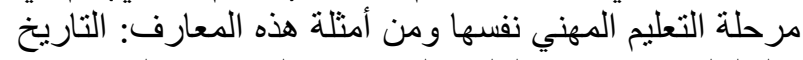

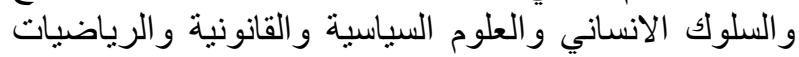

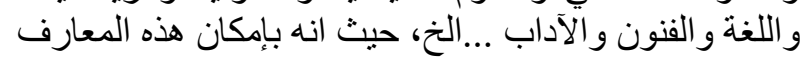

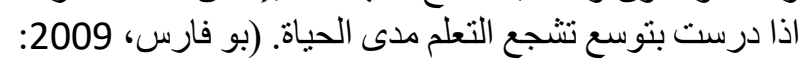

لذا يعد التعليم العام هو أساس تعلم و إكتساب معظم المهارات

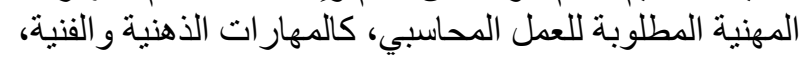

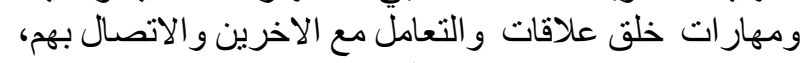

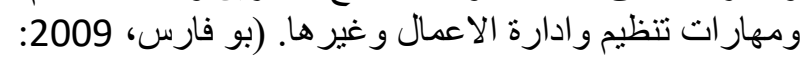

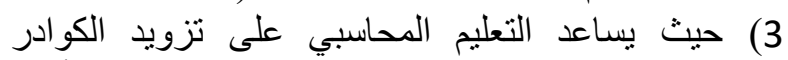

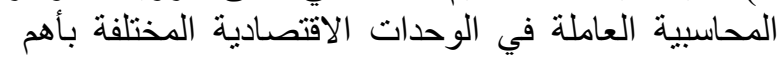

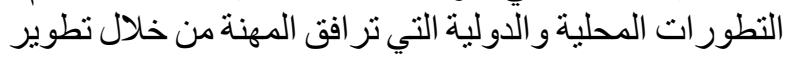
المبادئ و المعايير المحاسبية وتطولية تربير المحاسبين بالمعارف نطوير
2.1.3. معايير التعليم المحاسبي الدولية وأهميتها: معايير

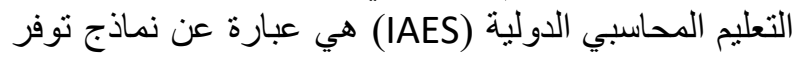

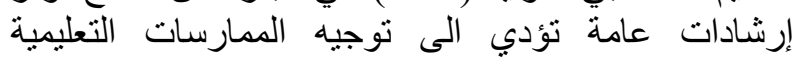

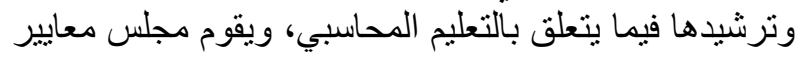

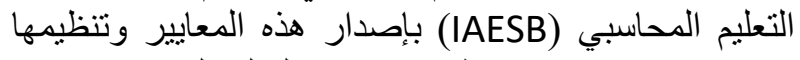

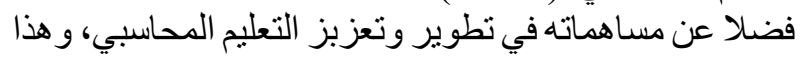

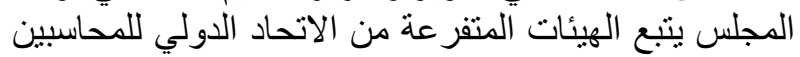

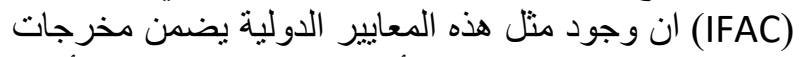

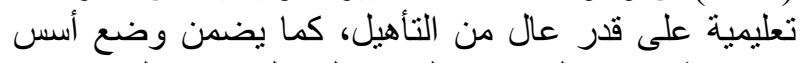

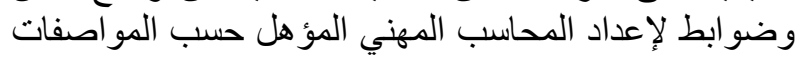
المحددة و الصادرة من الاتحاد الماد الدولي للمحاسبين (IFAC)

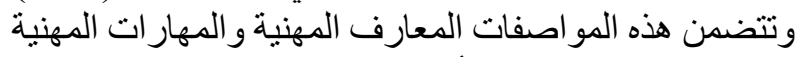

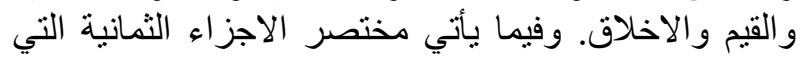

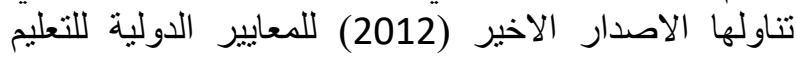

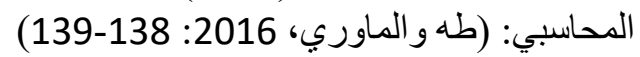

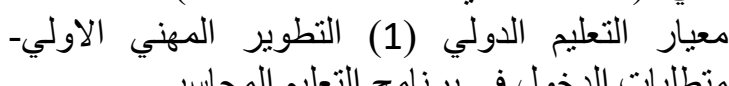
متطلبات الدخول في برنامج التعليم المحاسبي الإي التيري معيار التعليم الدولي (2) التطوير المهني الاوليـ الكفاءة التئي الفنية.

معيار التعليم الدولي (3) التطوير المهني الاوليالمهار ات المهنية. معيار التعليم الدولي (4) التطوير المهني الاوليــ القيم و الاخلاقيات و السلوكيات المعنية. معيار التعليم الدولي (5) التطوير المهني الاولي- الخبرة العملية.

معيار التعليم الدولي (6) التطوير المهني الاولي- تقييم الكفاءة المهنية. معيار التعليم الدولي (7) التطوير المهني الاوليـ التطوير المهني المستمر (التعليم المستمر ).

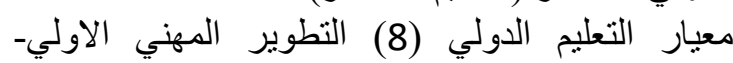
الكفايات للمدققين المهنيين.

مما سبق بتضح أن مجلس معايير التعلين التهين المحاسبي الدولي

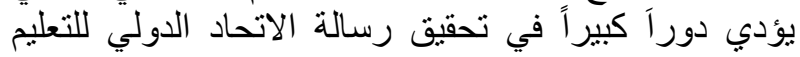

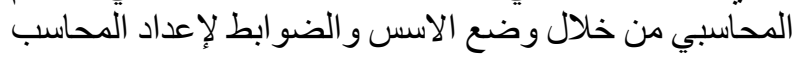

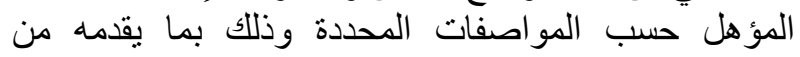
مساهمات في تطوير وتعزيز التعليم المحاسبي في في إطار

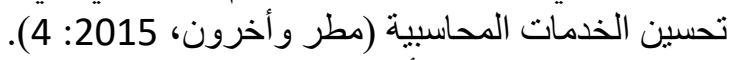
مما سبق يمكن تلخيص أهمية وجود معايير التعليم المحاسبي

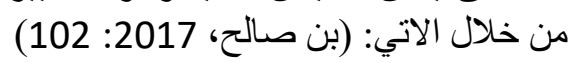
ت تخفيض مستوى التباين و الاختلاف في المناهج الدولية المحاسبية.

تسهيل حرية انتقال المحاسبين المهنيين والمؤهلين على الى لهين المستوى الدولي.

توفير معايير وارشادات دولية تمثل مرجعية اساسية

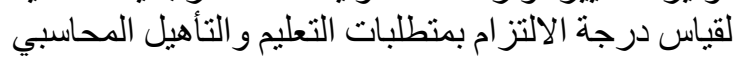

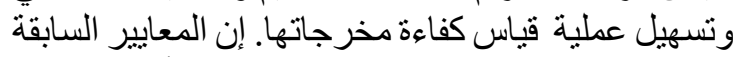

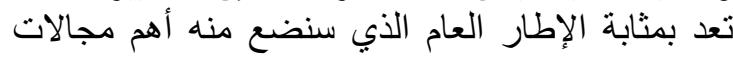

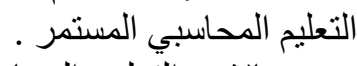

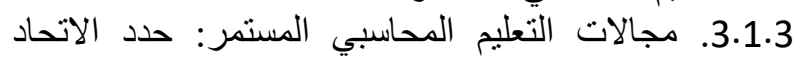

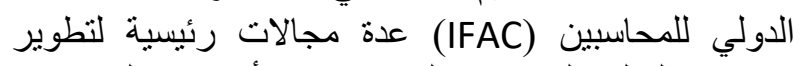

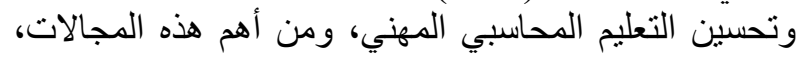


التغير ات التقنية والاقتصادية والاجتماعية فضلا عن تنمية

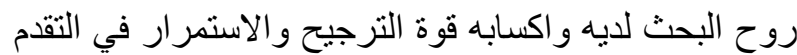

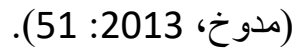
كما ان التغيير و التطور المتسار ع في مجالات تقنية المعلومات

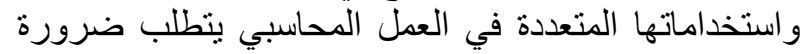

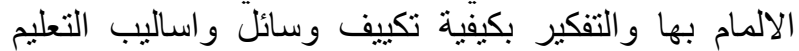

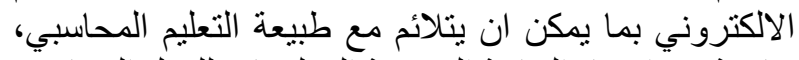

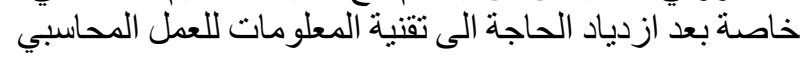

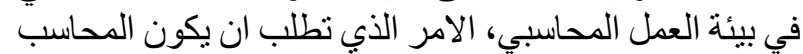

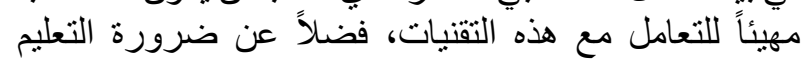

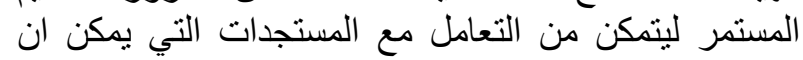

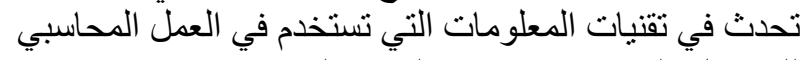

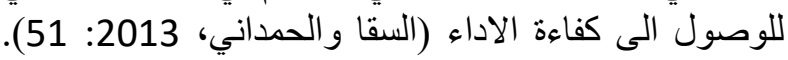

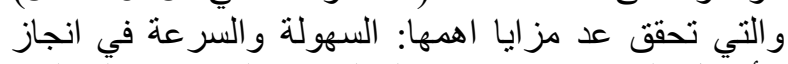

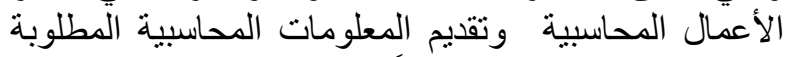

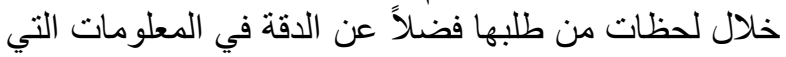
يعدهاو يقدمها النظام المحاسبي المحوسب بالِ بالإضافة الى الى توفيره

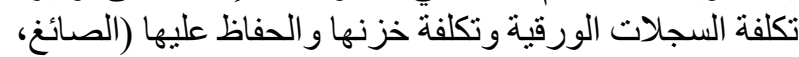

171: 2010

رابعاً: نرسيخ القيم والمبادئ الاخلاقية للمهنة (العمل وفقاً

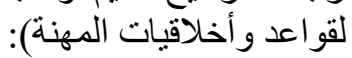

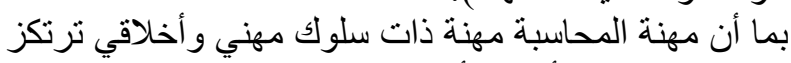

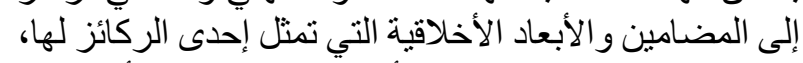

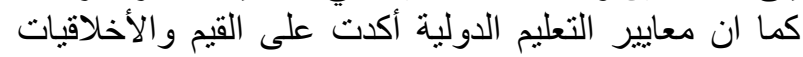

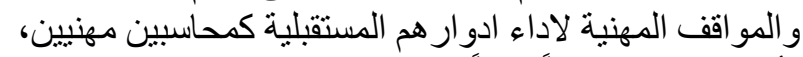

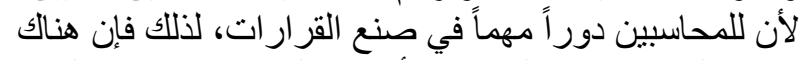

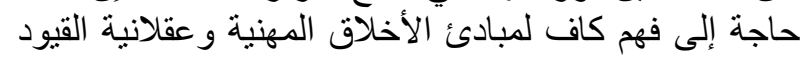

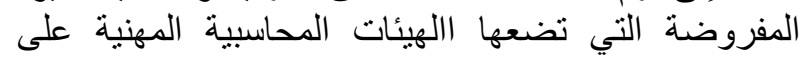

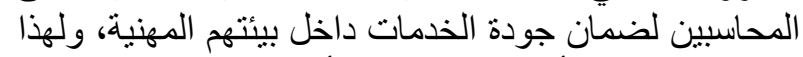

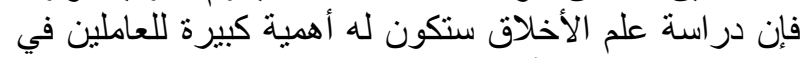

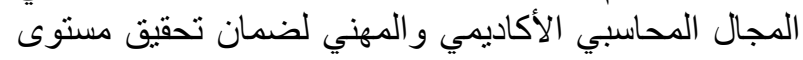

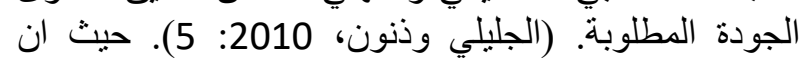

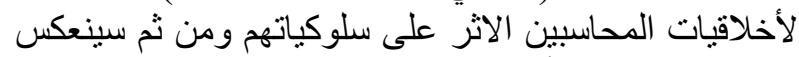

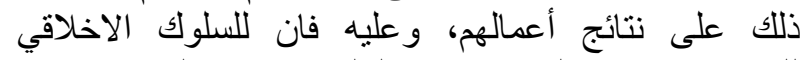

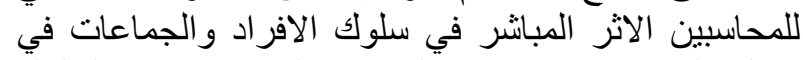

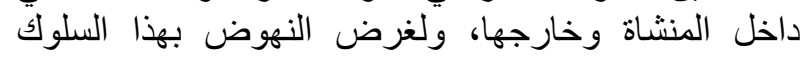

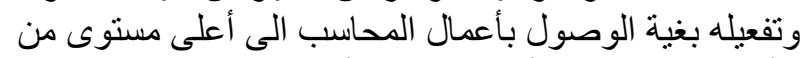

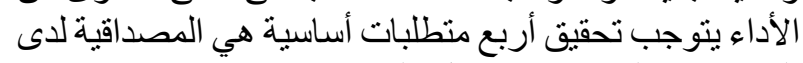

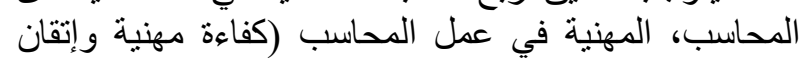

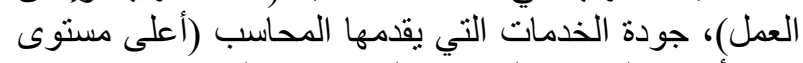

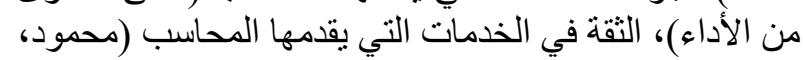

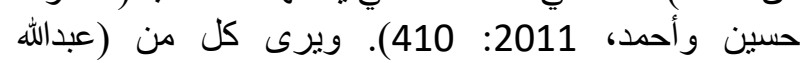

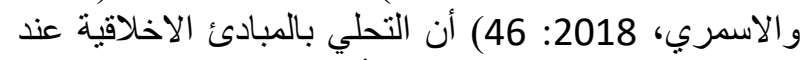

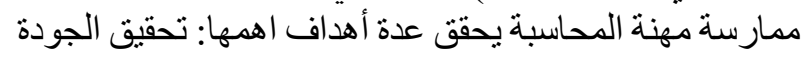

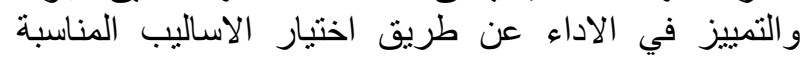

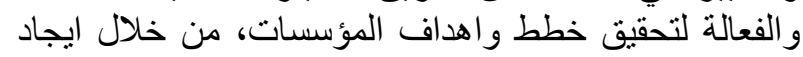

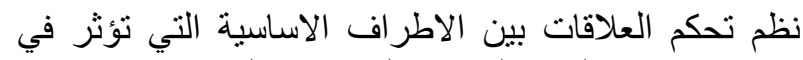

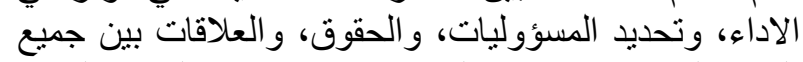

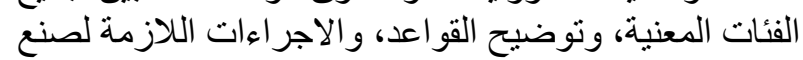

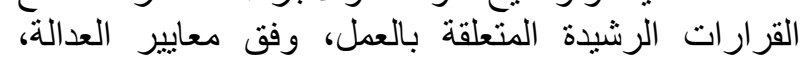

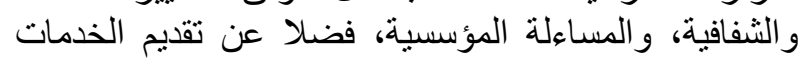

2003: المستجدة من خلال بر امج التعليم المحاسبي المستمر (Howieson, 86) ويرى كل من (كحيط وأحمد، 2016: 361 361) ان عملية التعليم

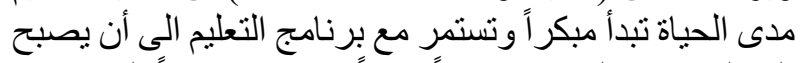

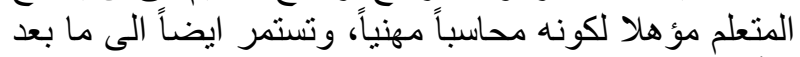

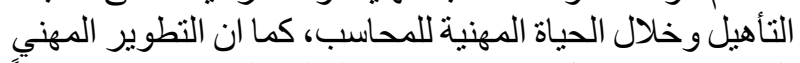

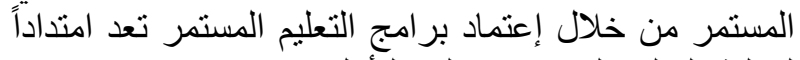

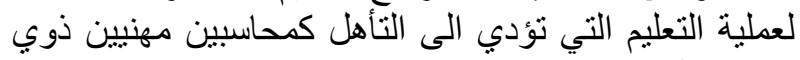
كفاءة عالية.

ثنانياً: المهار الية المهنية (التدريب و الخبرة المهنية):

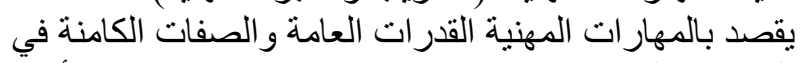

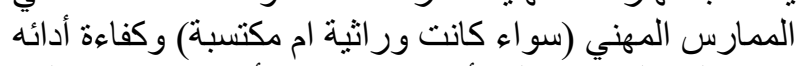

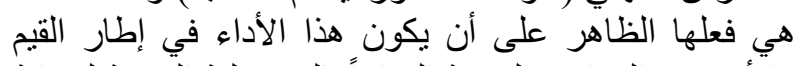

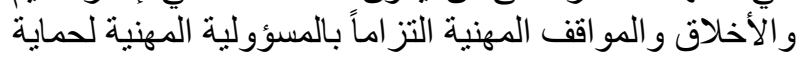

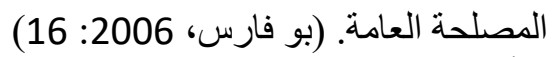

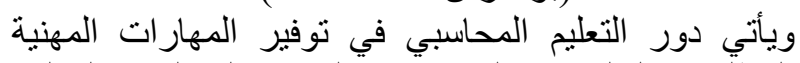

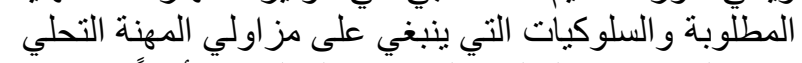

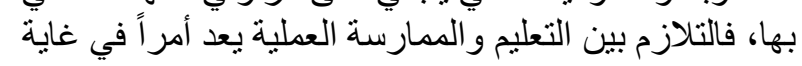

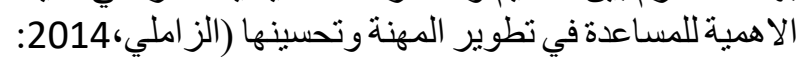

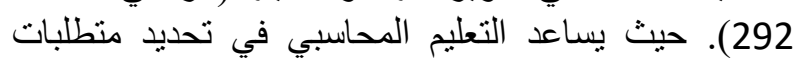

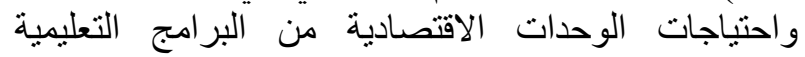

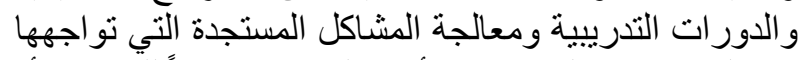

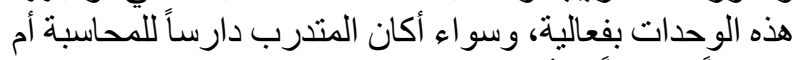

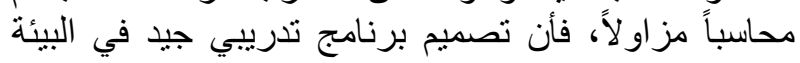

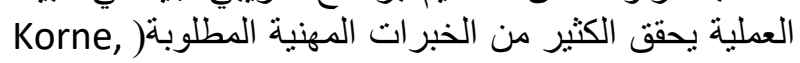

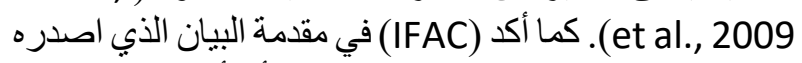

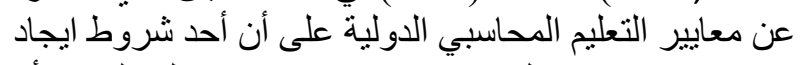

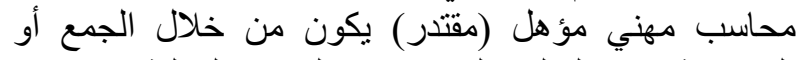

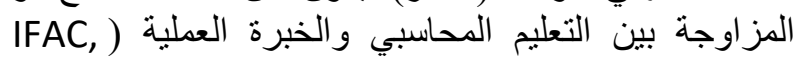
(2013: 22-23

مما سبق يتضح ان للتدريب و الخبرة المهنية أهمية كبيرة في

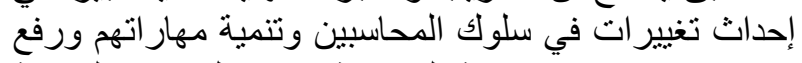

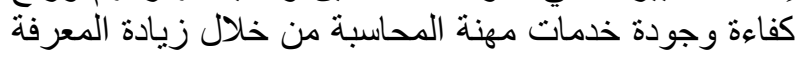

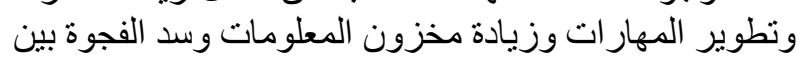
منطلبات سوق العمل و وامكانيات وقدر الترات المعات المحاسبين المهنية

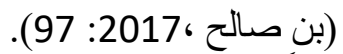
ثالثاً: المهار مات التقنية (الالكترونية):

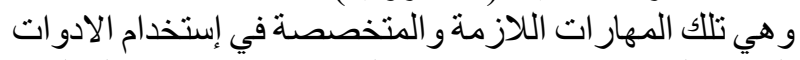

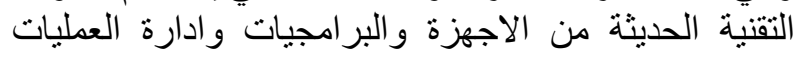

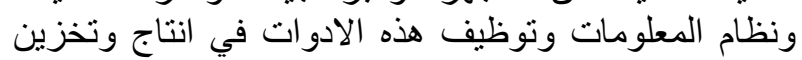

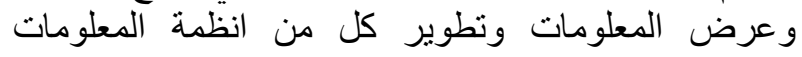

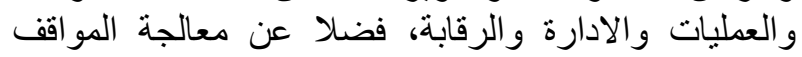

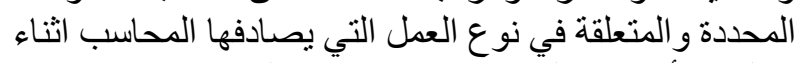

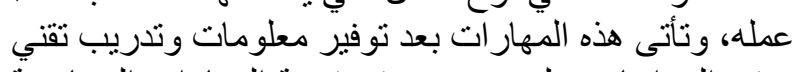

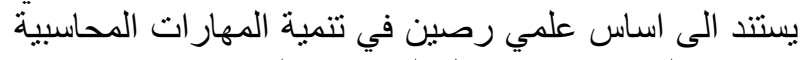

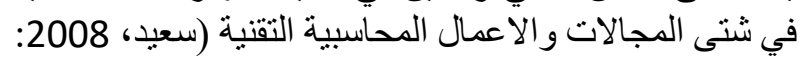

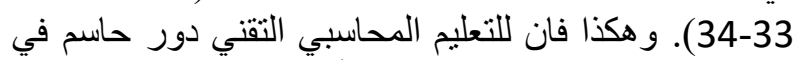

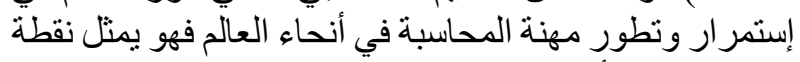

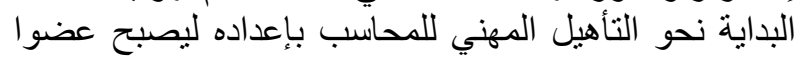

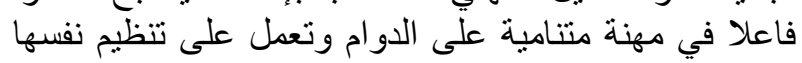

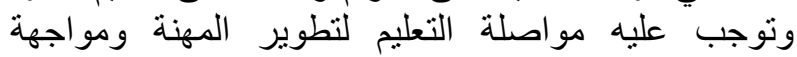


مما سبق يمكن تعريف جودة الاداء المحاسبي بانها الوسيلة

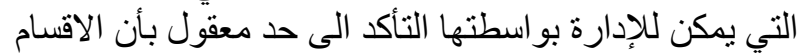

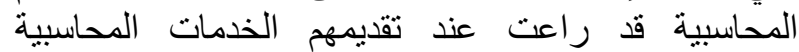

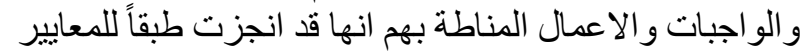

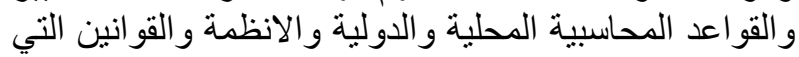

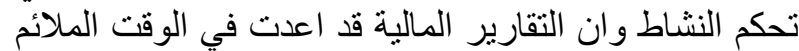

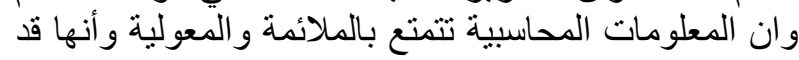

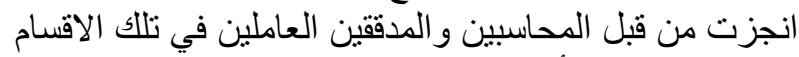

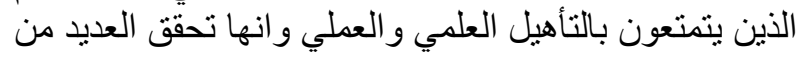

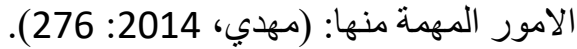

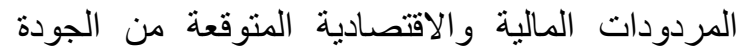

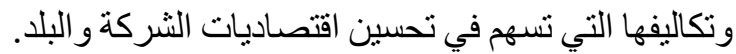

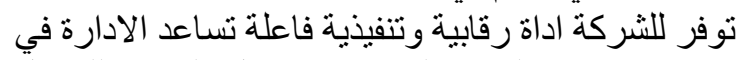

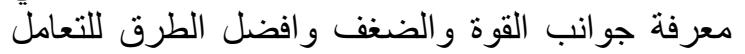
معها. توفر معلومات مهمة للإدارة يمكن الاستفادة منها في اتخاذ القرار ات ذات الطبيعة العملياتية و المالية. تسمح لإدارة الثركة ان تنافس بنجاح في اكثر من اسبقية تنافسية.

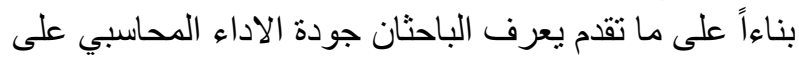

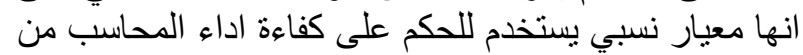

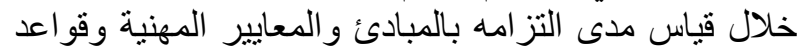

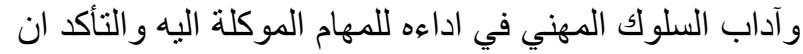

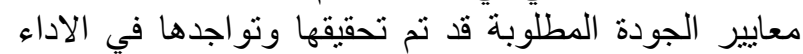

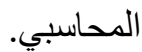

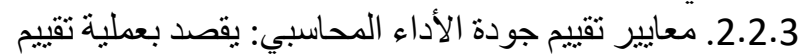

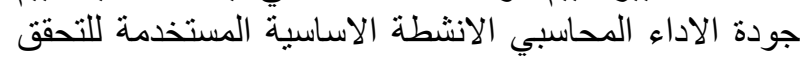

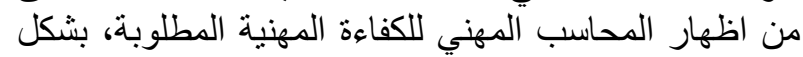

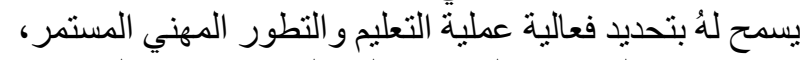

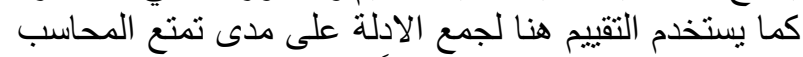

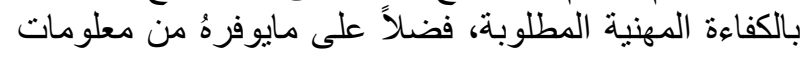

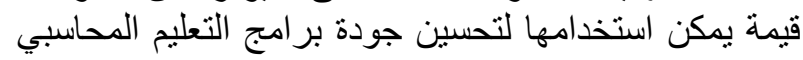

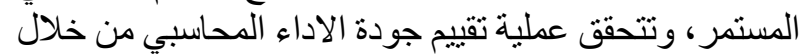

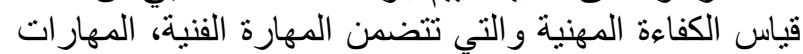

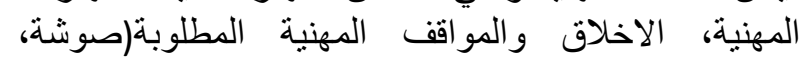

(30:2018

كما ان عملية تقييم الأداء تتطلب وجود دماء معايير أو أساس ينسب

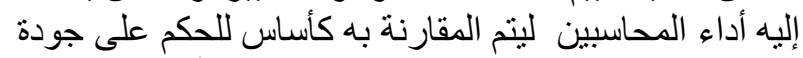

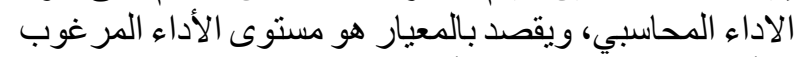

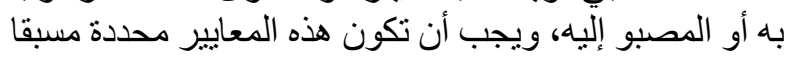

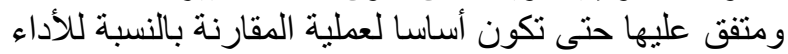

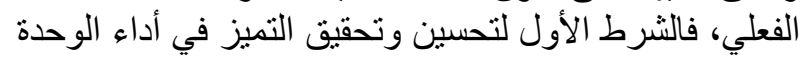

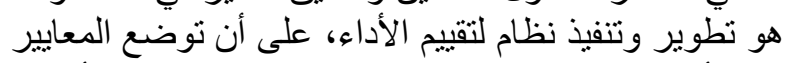

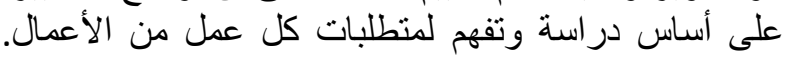

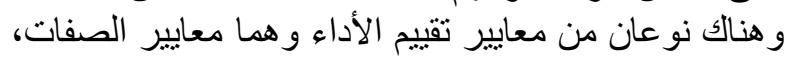

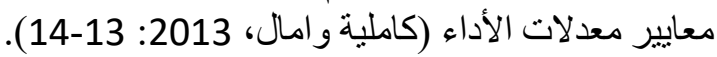

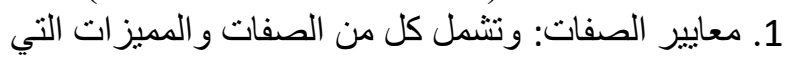

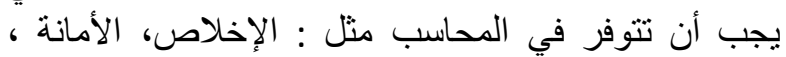
التعاون، ... الخ .و المعايير نو عان: أ. معايير ملموسة : يمكن قياسها بسهولة لدى المحاسب ، مثل المو اظبة على العمل و الدقة.
بكفاءة عالية من خلال رفع مستوى الاداء وتفعيل مبدا الرقابة

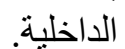
كما أن هناك بعض الصفات السلوكية يتطلب أن يتحلى بها

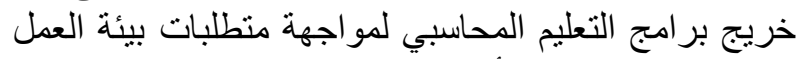

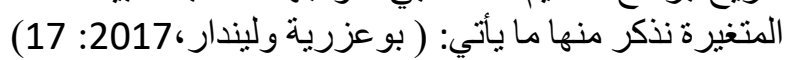

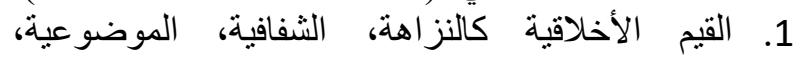

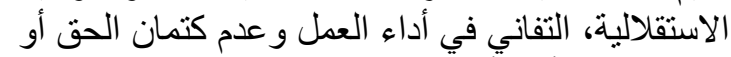

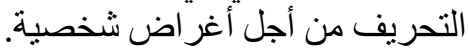

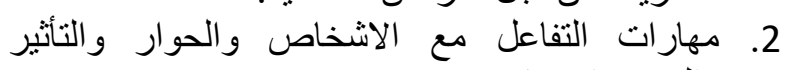
و التوجيه الإيجابي.

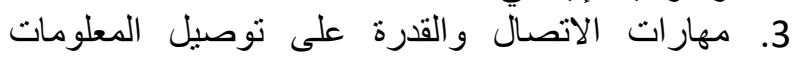

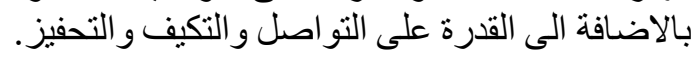

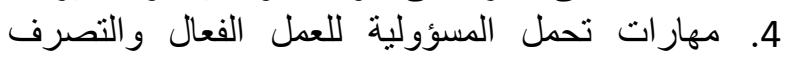
بمسؤولية.

يتضح مما سبق ان للتعليم المحاسبي أهمية كبيرة في بناء وتطوير المهار ات المهنية المطلوبة من خلان تلبيم البية احتياجاتها

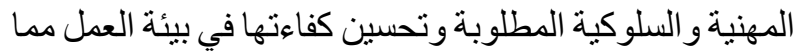

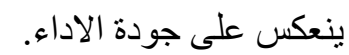
2.3. جودة الأداء المحاسبي:

1.2.3. مفهوم الجودة وجودة الأداء المحاسبي: يقصد بالجودة الأد الجية

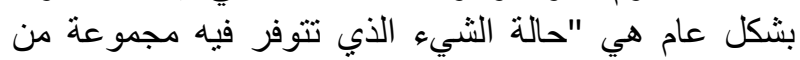

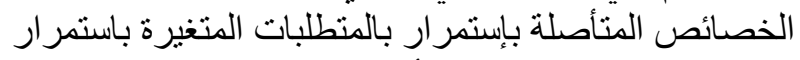

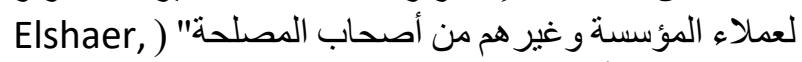
9 :2012).

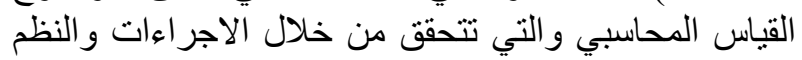

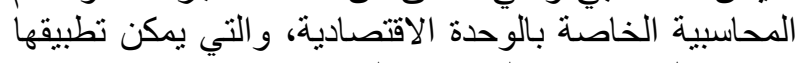

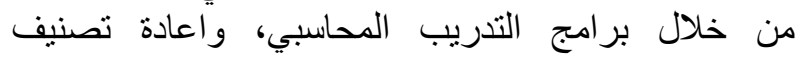

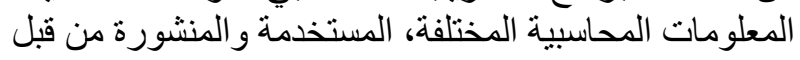
الوحدة الاقتصادية (2007: 3 Munteanu).

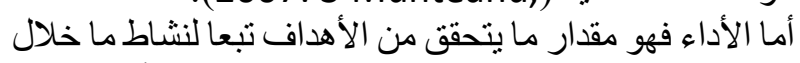

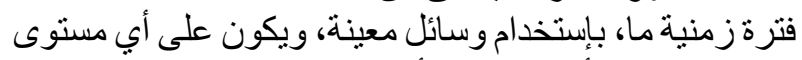

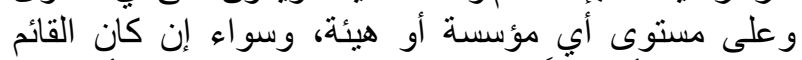

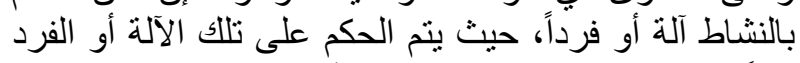

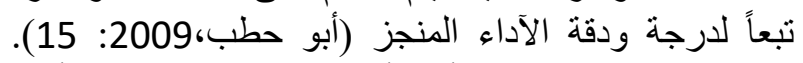

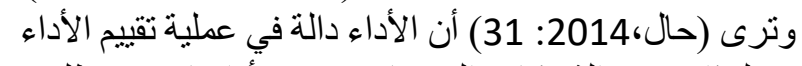

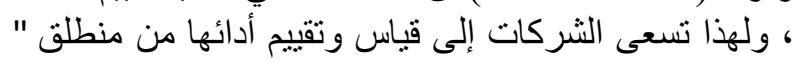

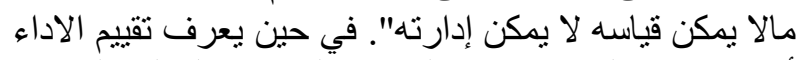

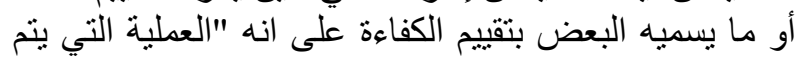

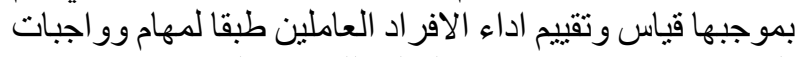

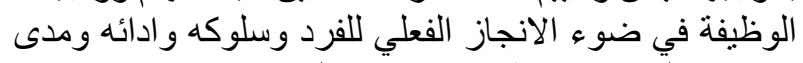

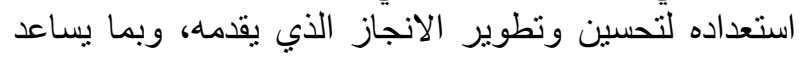

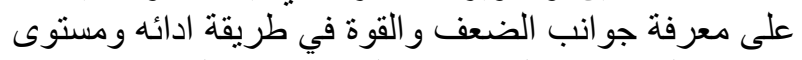

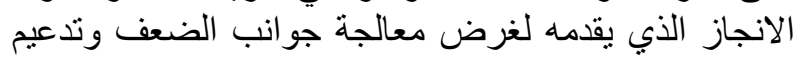

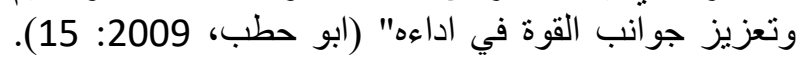

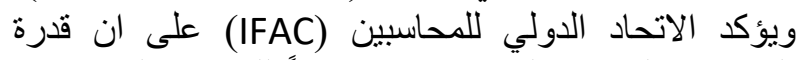

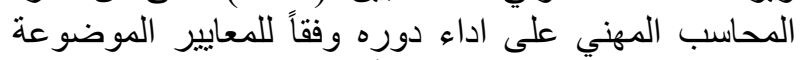
تتطلب منه دمج وتطبيق مكونات أساسية لتحقيق الكفاء الكفاءة المهنية

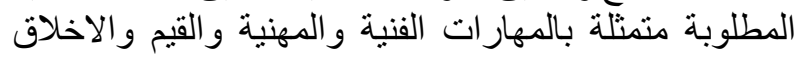

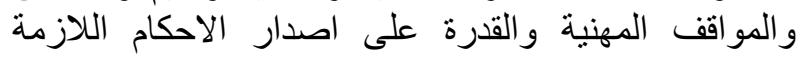
لمعالجتها (IFAC, 2015: 108). 


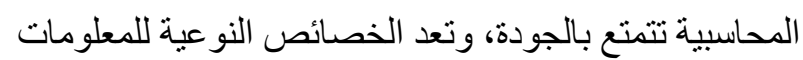

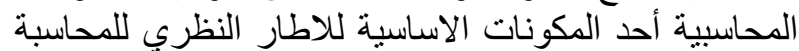

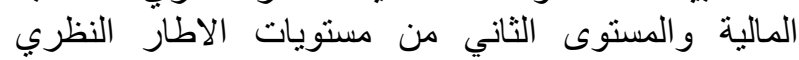

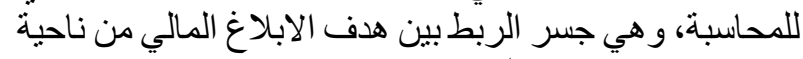

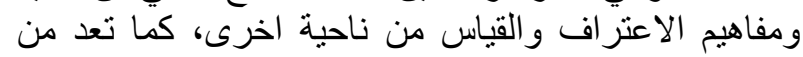

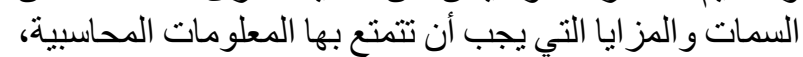

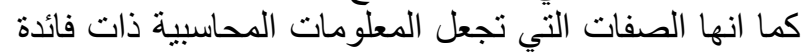

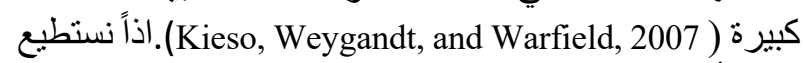

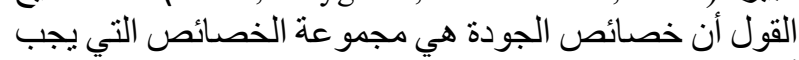

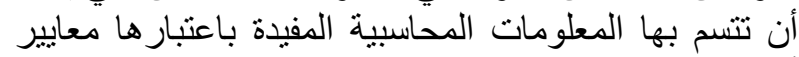

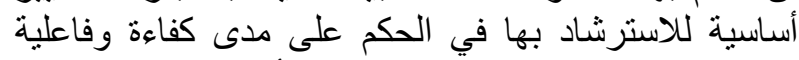

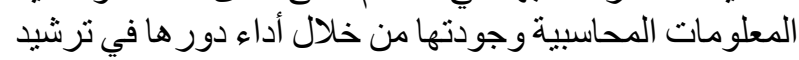

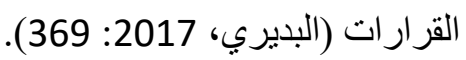

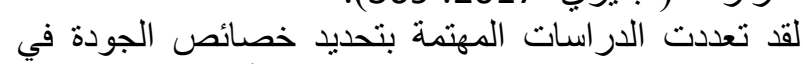

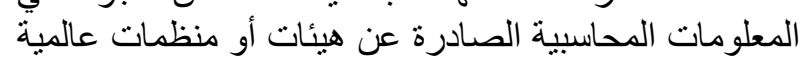

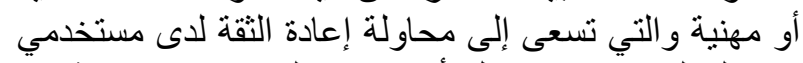

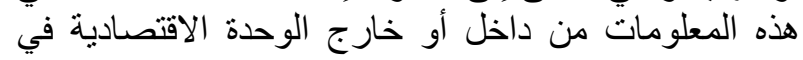

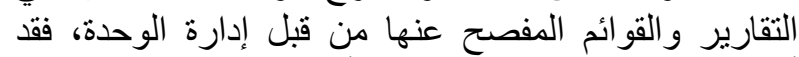

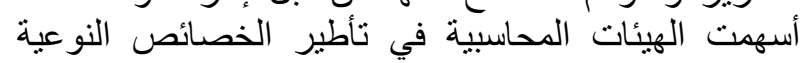

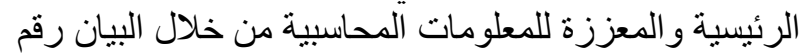

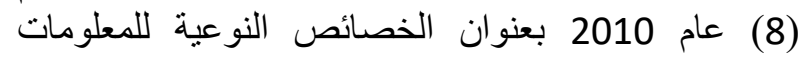

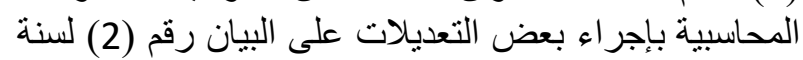

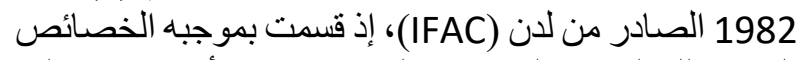

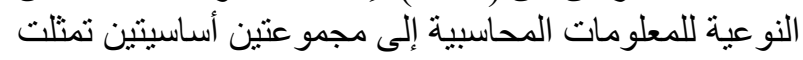

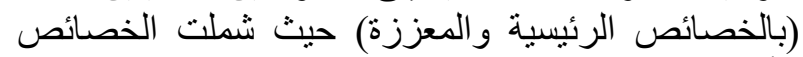

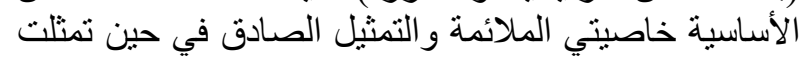

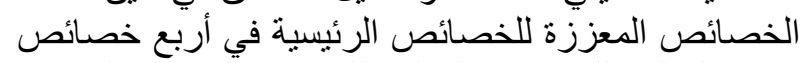

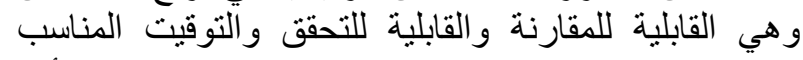

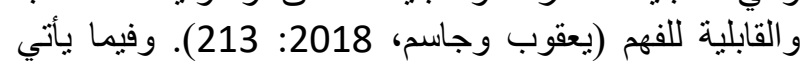
توضيح لكل منها:

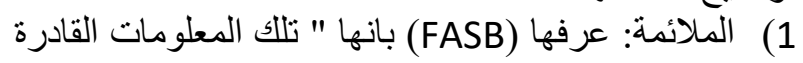

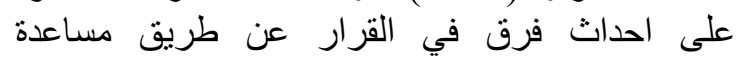

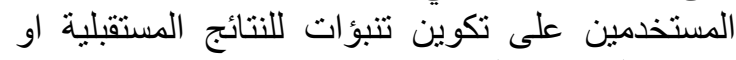

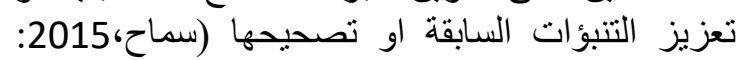

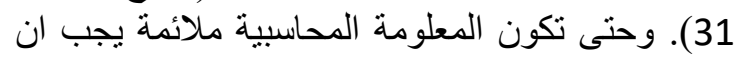

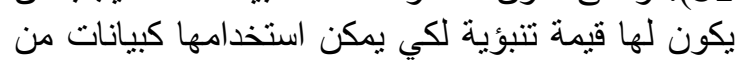

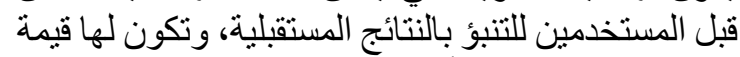

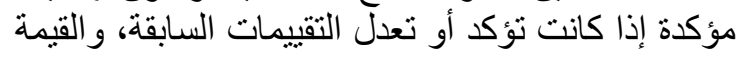

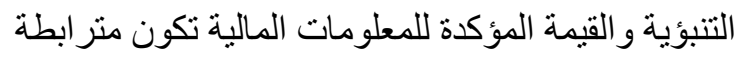

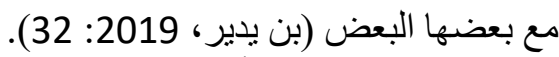

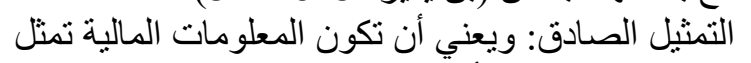

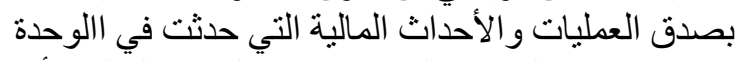

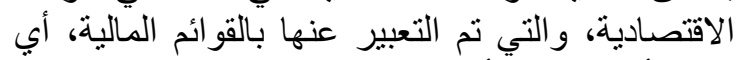

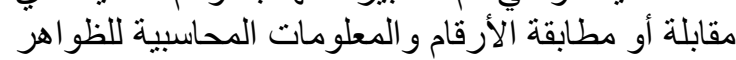

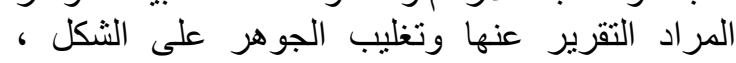

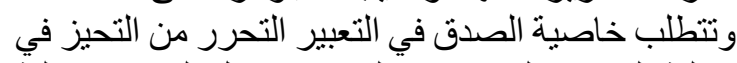

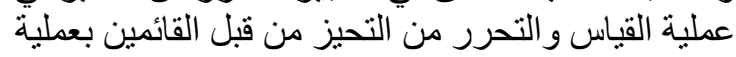

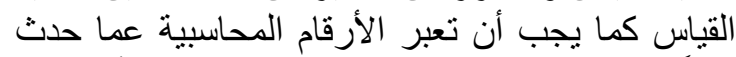

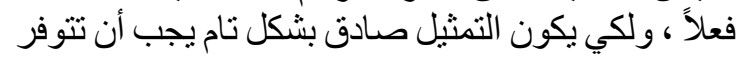

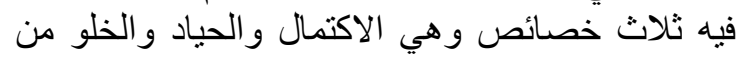
الأخطاء.( بن يدير، 2019: 33-34 الأنال
ب. معايير غير ملموسة : وهي التي يجد المقوم صعوبة في

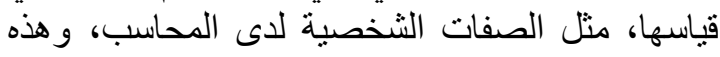

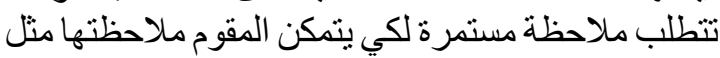

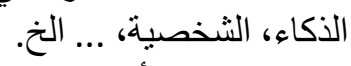
2. معايير معدلات الأداء : و هي تمثل المعيار الذي يتم مقارنتة

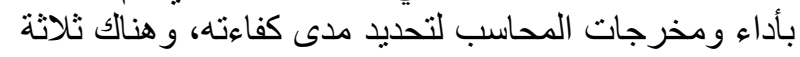
أنواع من معدلات الأداء يمكن إيضاحهاء باء بالآتي:

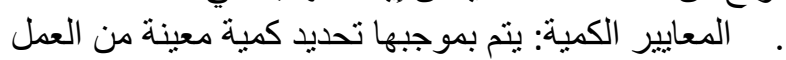

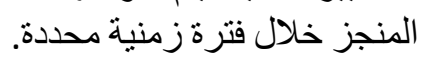

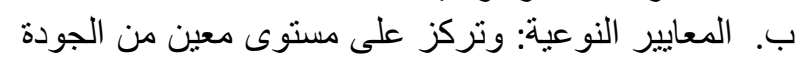
يجب على المحاسب أن يحققه مثل الإتقان.

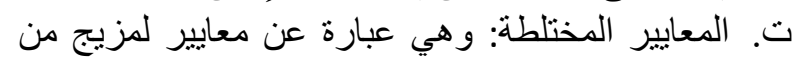

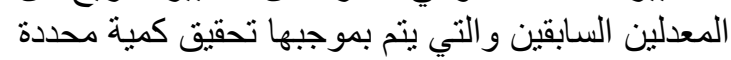

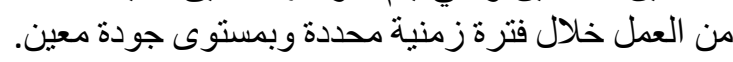

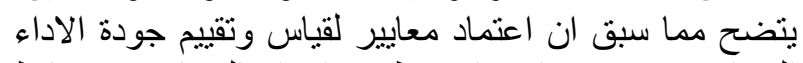

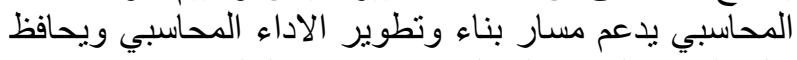

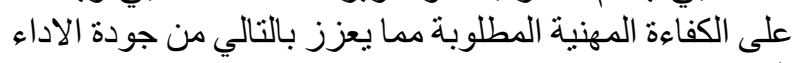

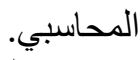

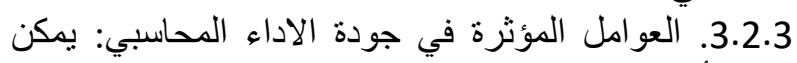
تحديد أهم العوامل المؤثرة على فئ جودة الاداء المحاء المبلي وكما

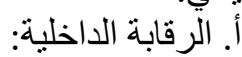

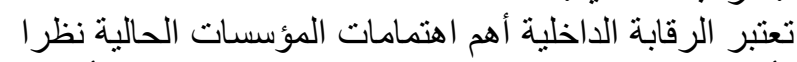

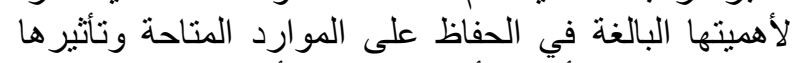

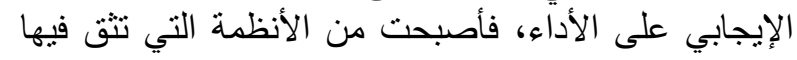

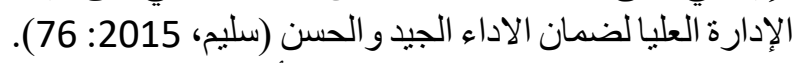

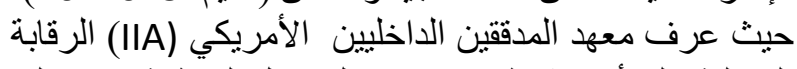

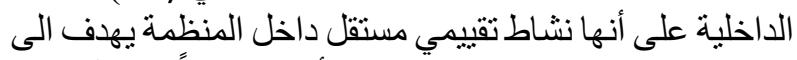

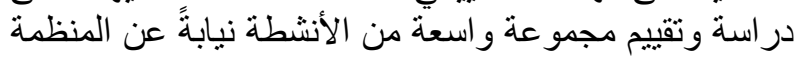

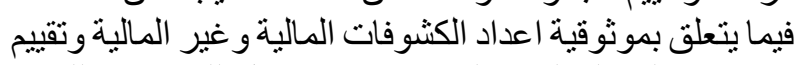

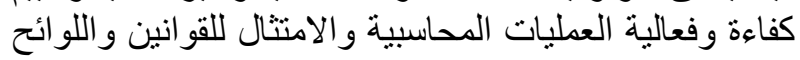

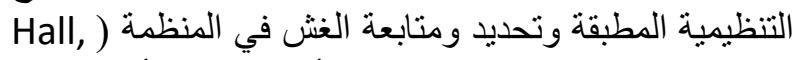

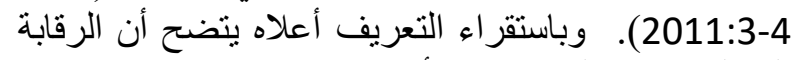

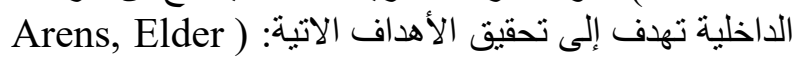

.(\& Beasley, 2012: 290 . الثقة بالقو ائم المالية: تقع مسؤولية إعداد القوائم المالية

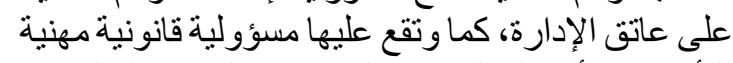

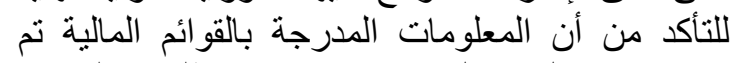

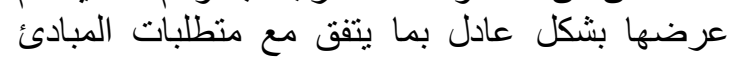

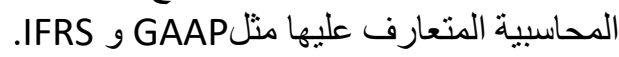

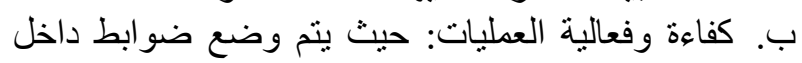

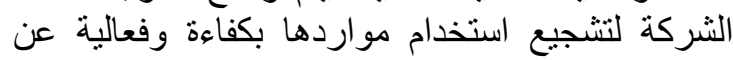

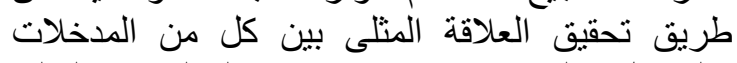

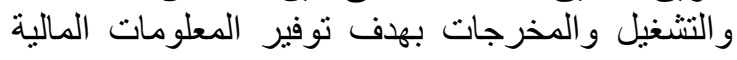

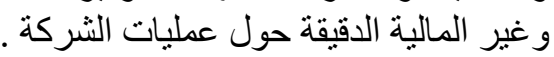

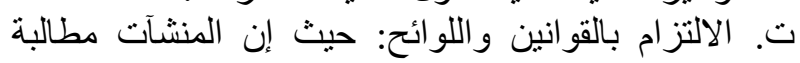

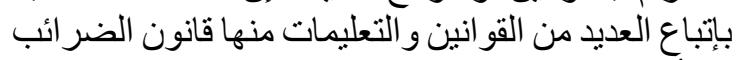

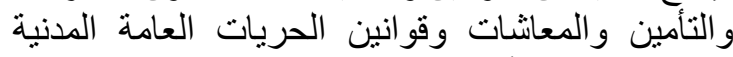

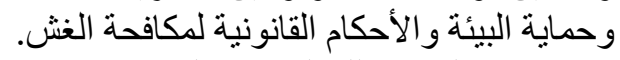

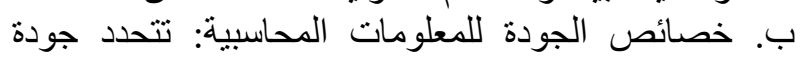
المعلومات بمجموعة من الخصائص و التي تجعل المعلومات لتصات 
المحاسبي الجيد و الفعال في إعداد وتأهيل كو ادر محاسبية وذلك المبار

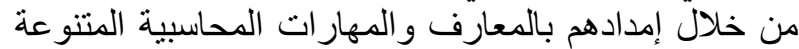

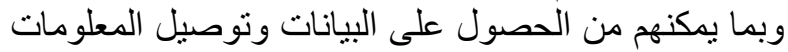

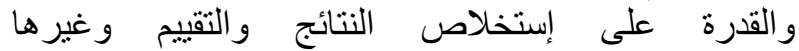
ولينار، (IFAC,2003: 4) ومن ابرز هذه المهارات: ( بوعزرية

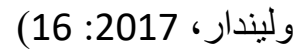

مهار ات تشغيل المعرفة كاستخدام الحاسب الآلي وتقنتية

المعلومات و استخدام الأساليب الاحصائية و الرياضئية.

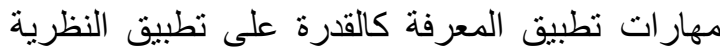
المحاسبية والقياس المحاسبي وكذا كتابة التقارير المهنية.

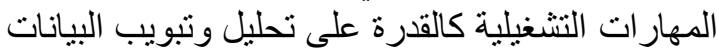

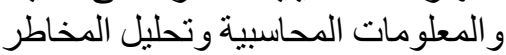

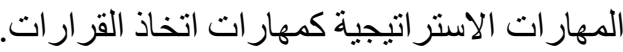

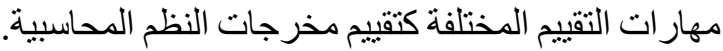
مهارات التفكير الانتقادي والإبداع في حل المشاكل

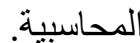
مهار ات التعليم الدحاسبي المستمر لفهم المستجدات بشأن المعرفة المحاسبية والقدرة على التعليم و التطوير الذاتي.

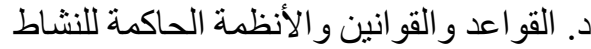

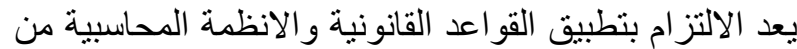

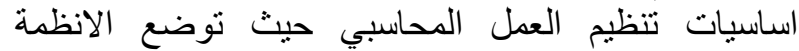

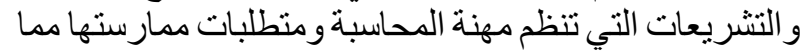
يؤهلهم لممارسة مهنة المحاسبة ويكفل جودة أدائهم فيما

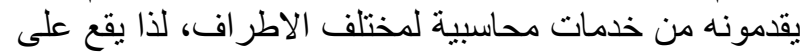

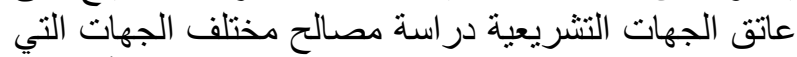

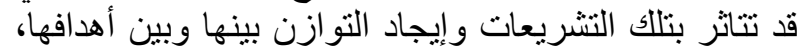

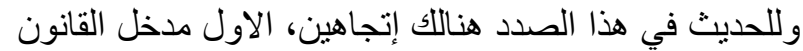

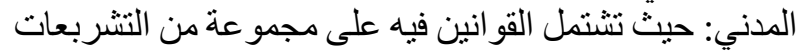

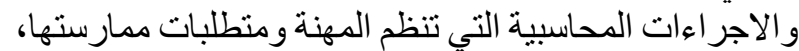

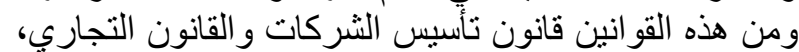

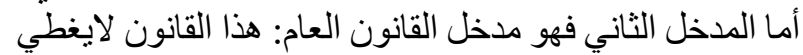

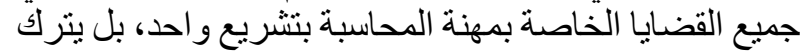

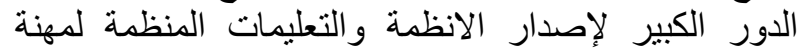

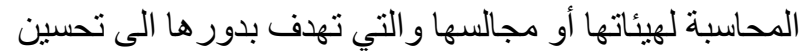

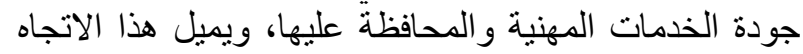

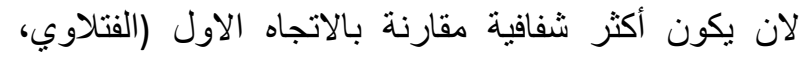

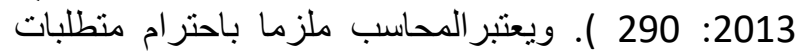

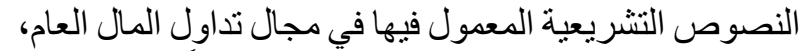

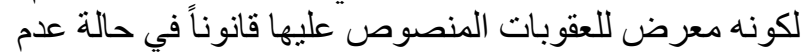

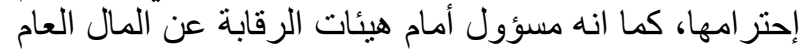

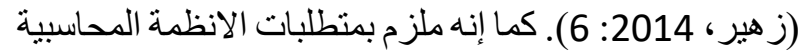

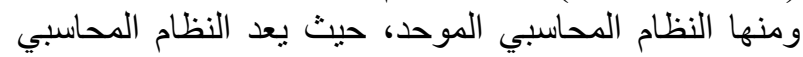
الموحد الصادر عام 1983 وقانون الثركات العامة الثة رقم 22

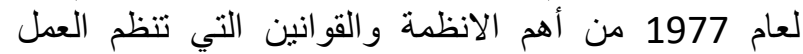

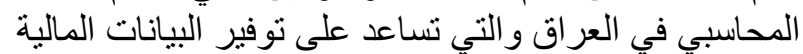

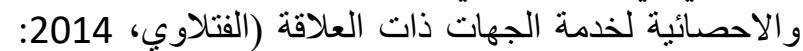

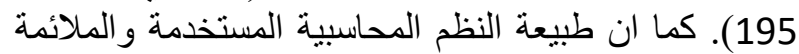

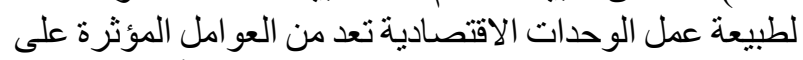

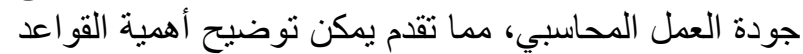

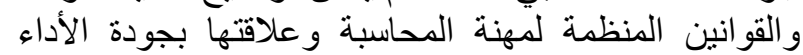

المحاسبي من خلال الآتي: (مهدي، 2013: 280-286).
3) القابلية للمقارنة: ويقصد بها إمكانية مقارنة القو ائم المالية

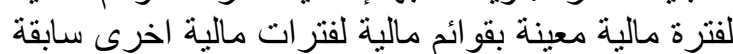

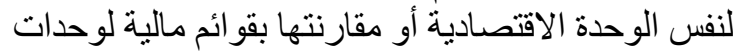

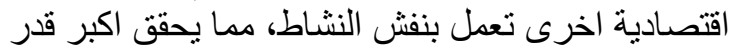

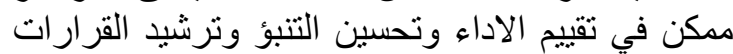
المختلفة، هذا وتقتضي عملية المقارنة الثبات فئني في استخدام

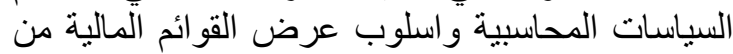

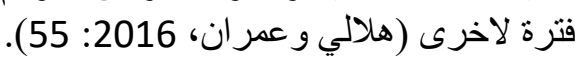
4) القابلية للتحقق: أي القدرة على الوصن التصول إلى نفس النتائج

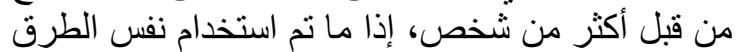

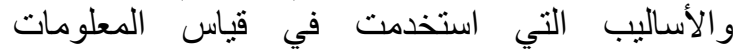
المحاسبية، و غالبا ما يستخدم مر ادف لكلمة للتحقق و هي التي

الموضو عية (سماح، 2015: 33 33).

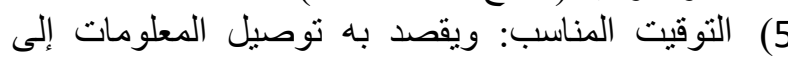

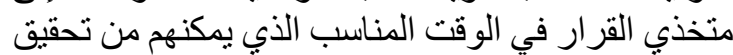

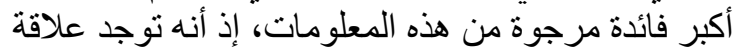

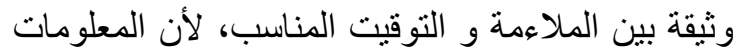

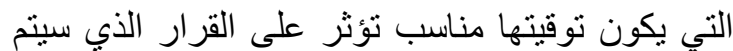

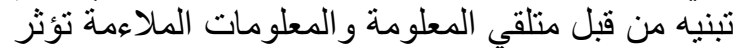

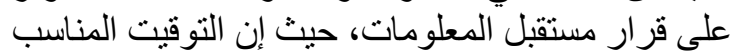

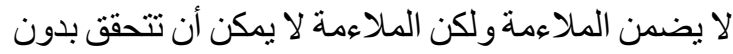
التوقيت المناسب في إيصال المعلومة (بوحفص، لألاعن 2018:

6) القابلية للفهم: ويقصد بها عرض المعلومات المحاسبية

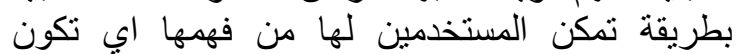

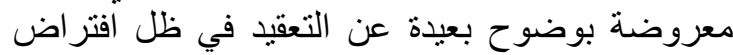

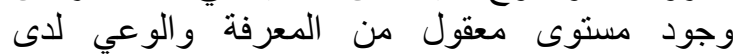

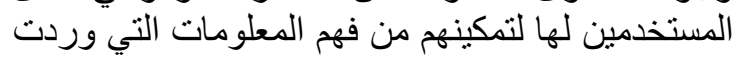

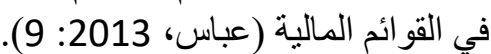

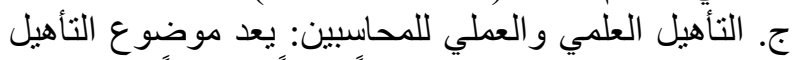

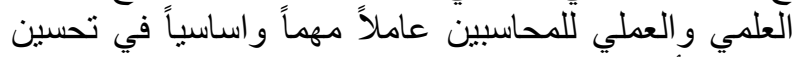

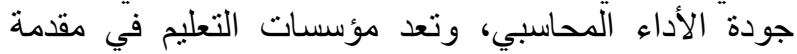

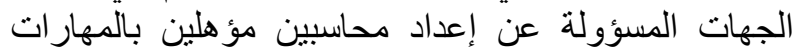

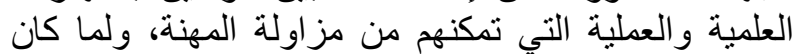

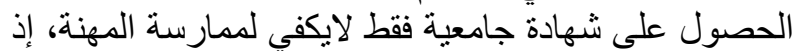

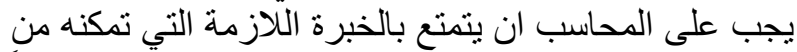

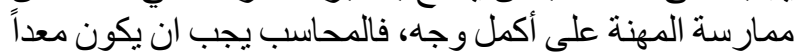

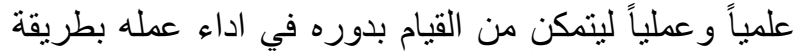

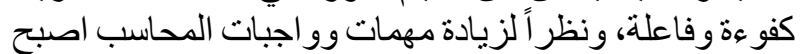

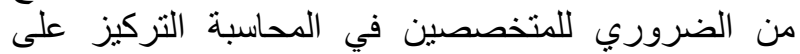

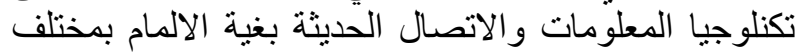

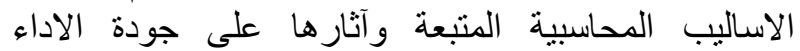

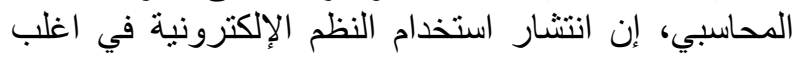

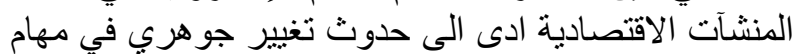

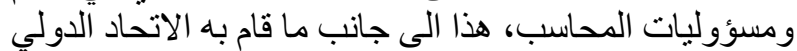

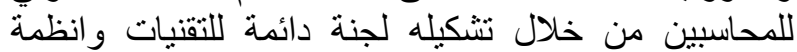

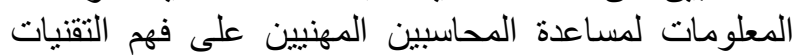

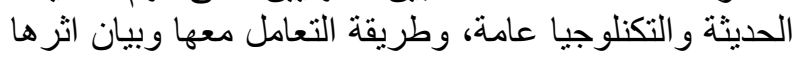

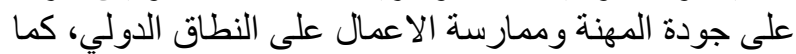

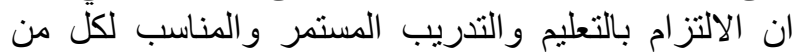

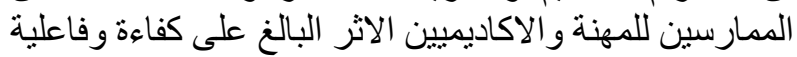

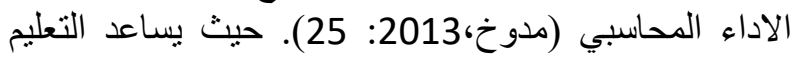


الجدول (3) أدناه و المتعلقة ببعد المهارات المعرفية المتمثل

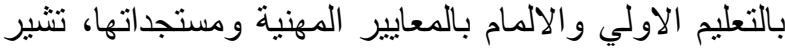

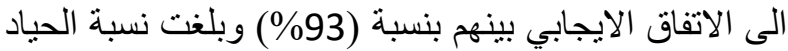

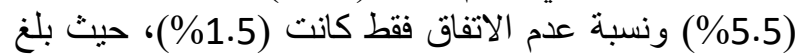

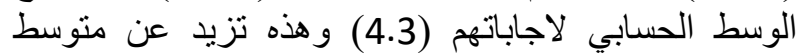

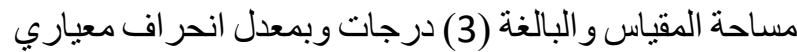
(0.61). إن النتائج المتحصلة تؤكد بأن هنالك إنفاق بدرجة الندافية

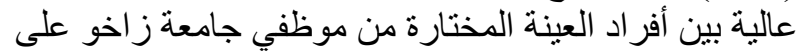
دور التعليم الاولي، التحسين المستمر للمهارات التينة المعرفية،

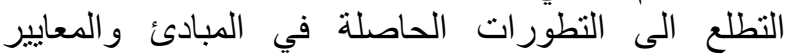

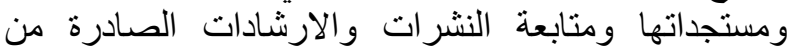

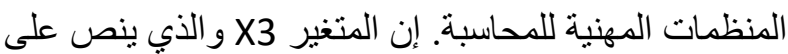

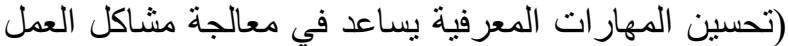

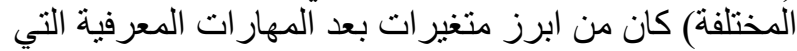

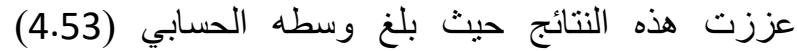
وبإنحر اف معياري (0.55) وجاءت نسبة إتفاق المستجييين له

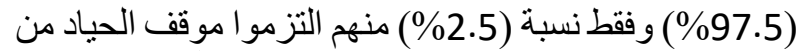

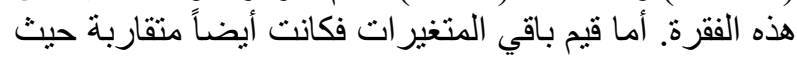

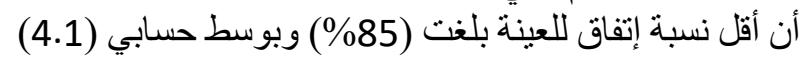

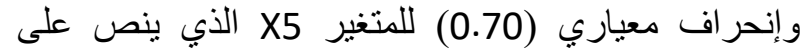

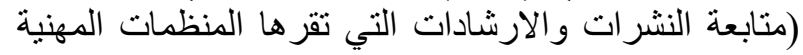

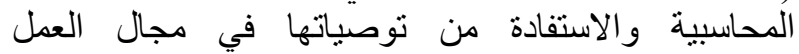

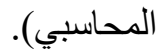

توفر ارشادات عامة تضبيق نقاط الاختلاف في التعبير او الممارسة في الظروف المتشابهة.

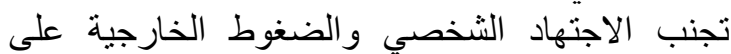
الوحدات المحاسبية وتوحد الممارسات المهادية المنية. تطور الكفاءة المهنية للمحاسبين. تساعد في الافصاح عن الحقائق. توحيد القياس و العرض للافساح عن الكفائل المتشابهة. تحديد طبيعة و عمق المسؤولية المهنية.

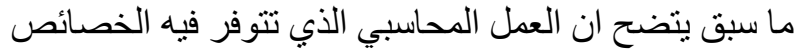

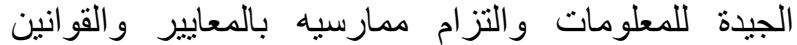
و الانظمة ويدار من قبل محاسبين مؤهلين تأهيلاً علمياً و عملياً

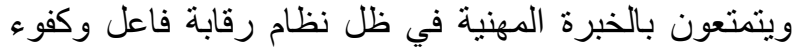

ينعكس تأثيره بشكل و ايجابي على جودة الاداء المحاسبي.

$$
\text { 1.4. وصف وتشخيص متغير ات البحث: العلي: }
$$

1.1.4. وصف وتتخيص أبعاد التعليم المحاسبي المستمر:

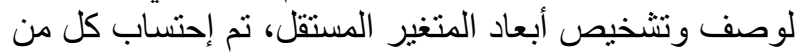

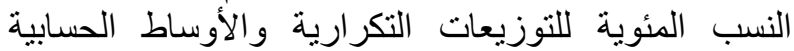

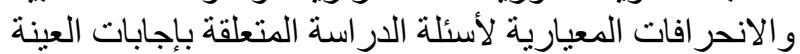

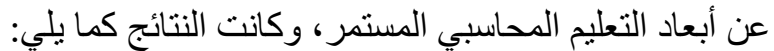

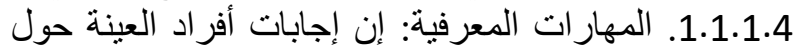

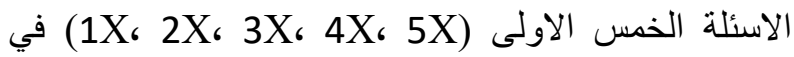

\begin{tabular}{|c|c|c|c|c|c|c|c|c|c|c|c|c|}
\hline \multirow{2}{*}{ المعياري } & \multirow{2}{*}{ الحسابي } & \multicolumn{2}{|c|}{ لا أتفق بشدة } & \multicolumn{2}{|c|}{ لا أتفق } & \multicolumn{2}{|r|}{ محايد } & \multicolumn{2}{|r|}{ أَتفق } & \multicolumn{2}{|c|}{ أتفق بشدة } & \multirow{2}{*}{ التنغيرات } \\
\hline & & $\%$ & التكر ار & $\%$ & التكرار & $\%$ & التنكر ار & & التكرار & & التكر ار & \\
\hline 0.504 & 4.45 & 0.0 & 0 & 0.0 & 0 & 0.0 & 0 & $55 . c$ & 22 & 45. & 18 & $\mathrm{X} 1$ \\
\hline 0.564 & 4.30 & 0.0 & 0 & 0.0 & 0 & 5.0 & 2 & 60.0 & 24 & 35. & 14 & $\mathrm{X} 2$ \\
\hline 0.554 & 4.53 & 0.0 & 0 & 0.0 & 0 & 2.5 & 1 & 42.5 & 17 & 55. & 22 & $\mathrm{X3}$ \\
\hline 0.757 & 4.13 & 0.0 & 0 & 5.0 & 2 & 7.5 & 3 & 57.5 & 23 & 30.1 & 12 & $\mathrm{X} 4$ \\
\hline 0.709 & 4.10 & 0.0 & 0 & 2.5 & 1 & 12.5 & 5 & 57.5 & 23 & 27.5 & 11 & $\mathrm{X} 5$ \\
\hline \multirow[t]{2}{*}{0.617} & \multirow[t]{2}{*}{4.30} & 0.0 & & 1.5 & & \multirow{2}{*}{\multicolumn{2}{|c|}{$\begin{array}{r}5.5 \\
5.5\end{array}$}} & \multirow{2}{*}{\multicolumn{4}{|c|}{930}} & \multirow{2}{*}{ الكلأشر } \\
\hline & & \multicolumn{4}{|c|}{1.5} & & & & & & & \\
\hline
\end{tabular}

جدول (3): التوزيعات التكر ارية والنسب المئوية والاوساط الحسابية والانحر افات المعيارية لبعد المهار ات المعرفية

المصدر: من إعداد الباحثين بالاعتماد على نتائج البرمجة

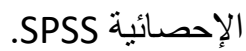

6X الذي ينص على (المشاركة في الدورات التدريبية يحسن

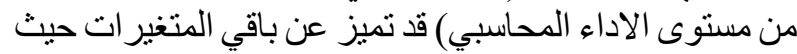

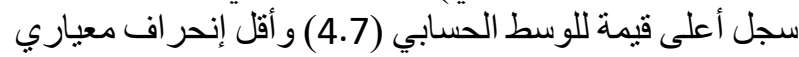

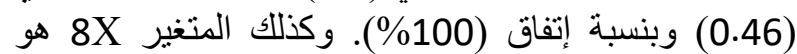
الآخر عزز من نسبة الاتفاق الكلية لبعد المهار ات المئه المهنية حيث

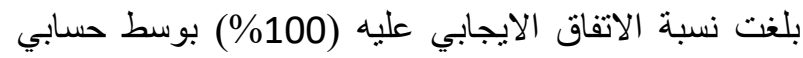

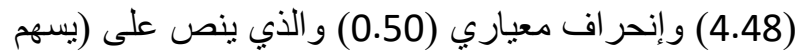

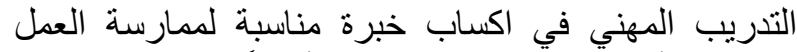
بنجاح)، و أما باقي المتغير ات فجاءت أيضاً بنسب إتفاق عالية كما هي مبينة في الجدول (4) الدناه
2.1.1.4. المهار ات المهنية: يلاحظ بأن إجابات العينة حول العئة

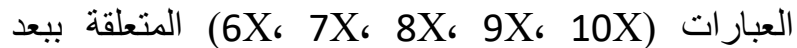
المهار ات المهنية تثير الى الاتفاق الايجابي بنسبة (6X7.5\%)

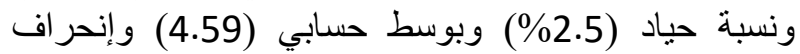

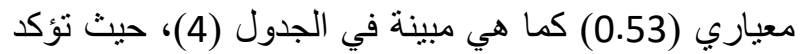

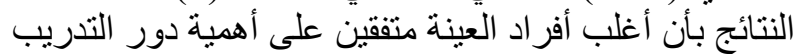

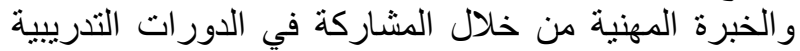

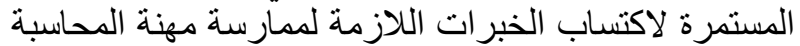

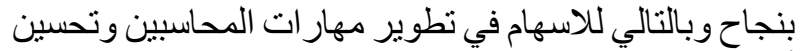
أدائهم لمعالجة مشاكل العمل المتوقعة بطرق مميزة. إن المتغير 
الجدول (4): التوزيعات التكر ارية و النسب المئوية والاوساط الحسابية و الانحر افات المعيارية لبعد المهار ات المهنية

\begin{tabular}{|c|c|c|c|c|c|c|c|c|c|c|c|c|}
\hline \multirow{2}{*}{ الالانحر اف } & \multirow{2}{*}{ الحسابي } & \multicolumn{2}{|c|}{ لا أتفق بشدة } & \multicolumn{2}{|r|}{ لا أتفق } & \multicolumn{2}{|r|}{ محايد } & \multicolumn{2}{|r|}{ أتفق } & \multicolumn{2}{|c|}{ أتفق بشدة } & \multirow{2}{*}{ المتغير ات } \\
\hline & & $\%$ & التكرار & $\%$ & التكر ار & $\%$ & التكر ار & & التكر ار & $\%$ & التكر ار & \\
\hline 0.464 & 4.70 & 0.0 & 0 & 0.0 & 0 & 0.0 & 0 & 70.6 & 28 & 30.0 & 28 & $x 6$ \\
\hline 0.552 & 4.55 & 0.0 & 0 & 0.0 & 0 & 2.5 & 1 & 40.6 & 16 & 57.5 & 23 & $\mathrm{X7}$ \\
\hline 0.506 & 4.48 & 0.0 & 0 & 0.0 & 0 & 0.0 & 0 & 52.5 & 21 & 47.5 & 19 & $x 8$ \\
\hline 0.567 & 4.55 & 0.0 & 0 & 0.0 & 0 & 5.0 & 2 & 35.0 & 14 & 60.0 & 24 & $\mathrm{X9}$ \\
\hline 0.572 & 4.68 & 0.0 & 0 & 0.0 & 0 & 5.0 & 2 & 22.5 & 9 & 72.5 & 29 & $\mathrm{X} 10$ \\
\hline \multirow[t]{2}{*}{0.532} & \multirow[t]{2}{*}{4.59} & 0.0 & & 0.0 & & 2.5 & & $44 .($ & & 53.5 & & المؤشر \\
\hline & & \multicolumn{4}{|c|}{0.0} & 2. & & \multicolumn{4}{|c|}{97.5} & الكلي \\
\hline
\end{tabular}

الالكترون: من إعداد الباحثين بالاعتماد على نتائج الحاسبة الالكترونية

(\%2\%) ونسبة (8) (\%) منهم إتخذو ا موقف الحياد وبوسط حسابي

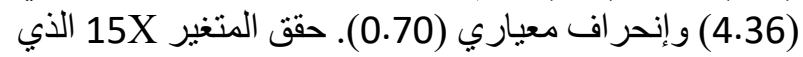

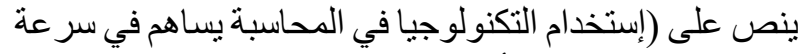

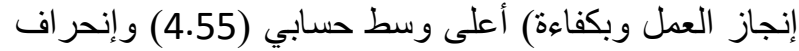

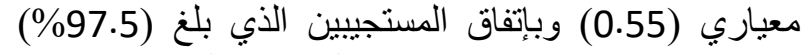

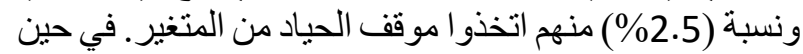

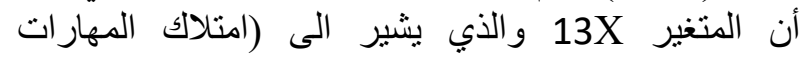

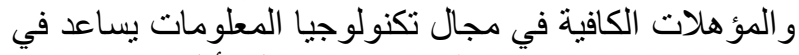

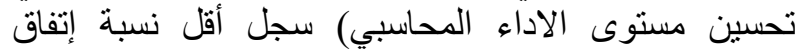

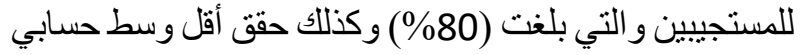
بنسبة (4.13) و إنحر اف معياري (0.75).
3.1.1.4. المهارات التقنية: إن إجابات افراد العينة حول

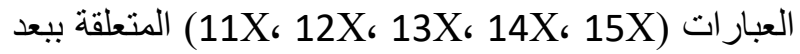

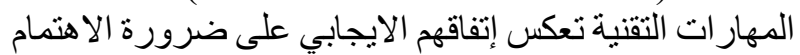

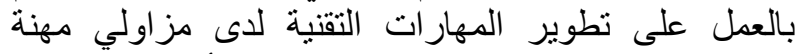

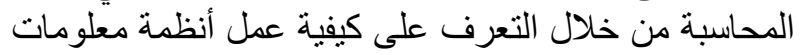

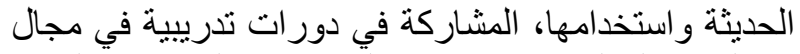
تكنولوجيا المعلومات لاكتساب المهار ات و والمؤهلات الكات الكافية

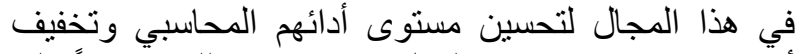

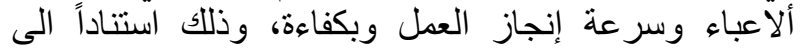

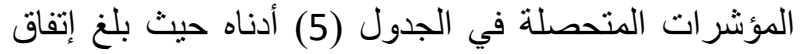
المستجيبين (90\%) في حين بلغت نسبة عدم الاتفاق فقط

الجدول (5): التوزيعات التكر ارية والنسب المئوية و الاوساط الحسابية والانحر افات المعيارية لبعد المهار ات التقنية

\begin{tabular}{|c|c|c|c|c|c|c|c|c|c|c|c|c|}
\hline \multirow{2}{*}{ الاعياري } & \multirow{2}{*}{ الحسابي } & \multicolumn{2}{|c|}{ لا أتفق بشدة } & \multicolumn{2}{|r|}{ لا أتفق } & \multicolumn{2}{|c|}{ محايد } & \multicolumn{2}{|r|}{ أتفق } & \multicolumn{2}{|c|}{ أتنقق بشدة } & \multirow{2}{*}{ المتغيرات } \\
\hline & & $\%$ & التكر ار & $\%$ & التكر ار & $\%$ & التكر ار & $\%$ & التكر ار & $\%$ & التكر ار & \\
\hline 0.667 & 4.38 & 0.0 & 0 & 0.0 & 0 & 10.0 & 4 & 42.5 & 17 & 47.5 & 19 & X11 \\
\hline 0.640 & 4.28 & 0.0 & 0 & 0.0 & 0 & 10.0 & 4 & 52.5 & 21 & 37.5 & 15 & $\mathrm{X} 12$ \\
\hline 0.939 & 4.20 & 0.0 & 0 & 7.5 & 3 & 12.5 & 5 & 32.5 & 13 & 47.5 & 19 & $\mathrm{X} 13$ \\
\hline 0.712 & 4.43 & 0.0 & 0 & 2.5 & 1 & 5.0 & 2 & 40.0 & 16 & 52.5 & 21 & X14 \\
\hline 0.552 & 4.55 & 0.0 & 0 & 0.0 & 0 & 2.5 & 1 & 40.0 & 16 & 57.5 & 23 & X15 \\
\hline \multirow{2}{*}{0.702} & \multirow{2}{*}{4.36} & 0.0 & & 2.0 & & 8.0 & & 41.5 & & 48.5 & & \multirow{2}{*}{ الكلي } \\
\hline & & \multicolumn{4}{|c|}{2.0} & 8. & & \multicolumn{4}{|c|}{90.0} & \\
\hline
\end{tabular}

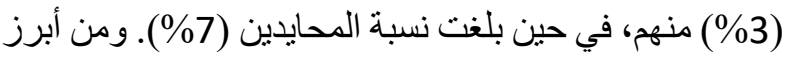

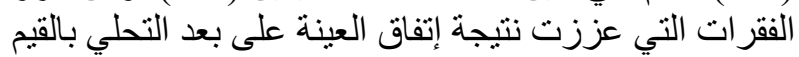

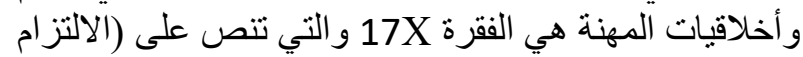

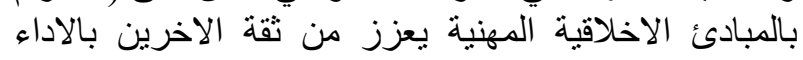

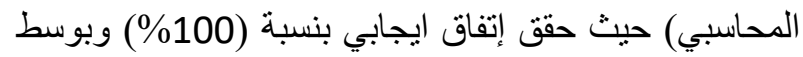

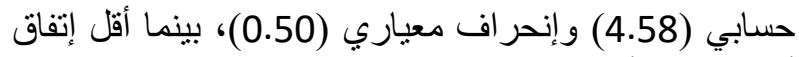
أيجابي بين أفراد العينة كان للفقرة 18X بنسبة (0.50) (82.5\%)

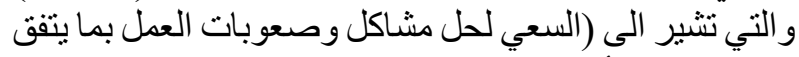
مع قواعد وأخلاقيات المهنة) وبوسط حسابي (4.13)
المصدر: من إعداد الباحثين بالاعتماد على نتائج الحاسبة

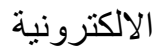

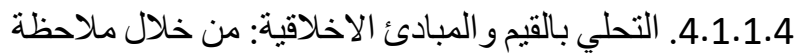
إجابات العينة المأخودة حول الفقرات (16X، 17X، 18X)

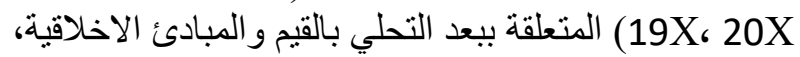

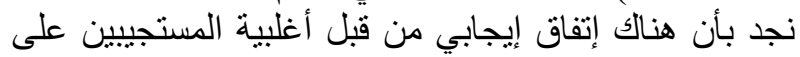

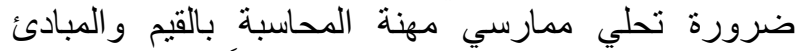
الاخلاقية لمهنة المحاسبة بما يعكس إيجاباً على تعزيز نقالقية

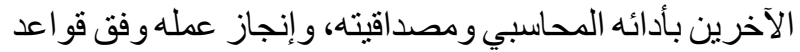
ومعايير أخلاقية مناسبة، وذللك بالإستناد الى النتائج المتحققة

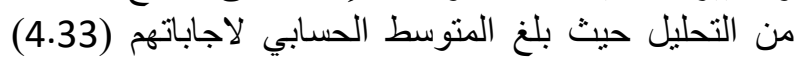
بإنحر اف معياري (0.73) وبإتفاق (90\%) منهم و عدم اتفاق لان 
وبإنحر اف معياري (0.75) كما هي واضحة في الجدول (6) أدناه:

الجدول (6): التوزيعات التكر ارية و النسب المئوية و الاوساط الحسابية و الانحر افات المعيارية لبعد التحلي بالقيم و المبادئ الاخلاقية

\begin{tabular}{|c|c|c|c|c|c|c|c|c|c|c|c|c|}
\hline \multirow{2}{*}{ المعياري } & \multirow{2}{*}{ الحسابي } & \multicolumn{2}{|c|}{ لا أتفق بشدة } & \multicolumn{2}{|r|}{ لا أتفق } & \multicolumn{2}{|r|}{ محايد } & \multicolumn{2}{|r|}{ أنفق } & \multicolumn{2}{|c|}{ أتفق بشدة } & \multirow{2}{*}{ المتغير ات } \\
\hline & & $\%$ & التكر ار & $\%$ & التكر ار & $\%$ & التكر ار & $\%$ & التكر ار & $\%$ & التكر ار & \\
\hline 0.591 & 4.60 & 0.0 & 0 & 0.0 & 0 & 5.0 & 2 & 30.0 & 12 & 65.0 & 26 & X16 \\
\hline 0.501 & 4.58 & 0.0 & 0 & 0.0 & 0 & 0.0 & 0 & 42.5 & 17 & 57.5 & 23 & $\mathrm{X} 17$ \\
\hline 0.757 & 4.13 & 0.0 & 0 & 2.5 & 1 & 15.0 & 6 & 50.0 & 20 & 32.5 & 13 & $\mathrm{X} 18$ \\
\hline 0.800 & 4.23 & 0.0 & 0 & 5.0 & 2 & 7.5 & 3 & 47.5 & 19 & 40.0 & 16 & X19 \\
\hline 1.027 & 4.15 & 5.0 & 2 & 2.5 & 1 & 7.5 & 3 & 42.5 & 17 & 42.5 & 17 & $\mathrm{X} 20$ \\
\hline \multirow[t]{2}{*}{0.735} & \multirow[t]{2}{*}{4.33} & 1.0 & & 2.0 & & 7.0 & & 42.5 & & 47.5 & & \multirow{2}{*}{ الكلئ } \\
\hline & & \multicolumn{4}{|c|}{3.0} & & & \multicolumn{4}{|c|}{90.0} & \\
\hline
\end{tabular}

و وإنحر اف معياري (0.63) وبنسبة إتفاق بلغت (9.5.5\%) (292.5)

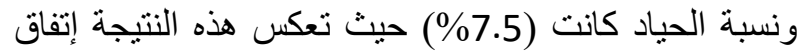
العينة المأخوذة على أن نكون مخرجات التهات العملية المحاسبية

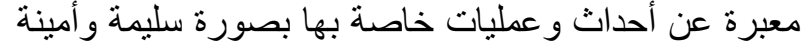

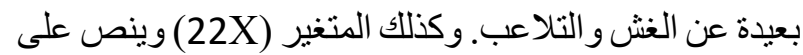

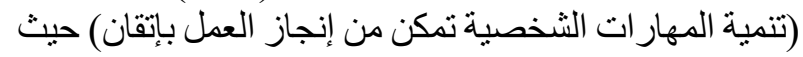

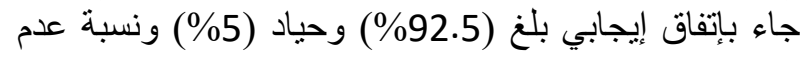

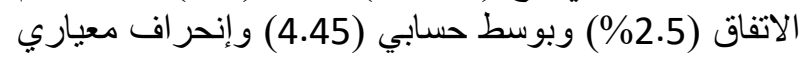

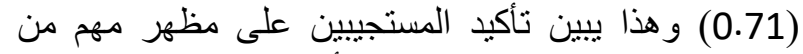

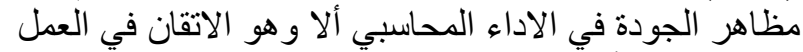

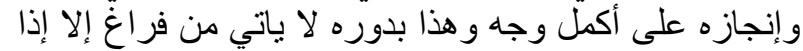

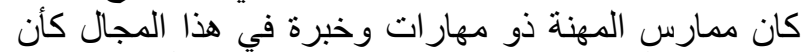

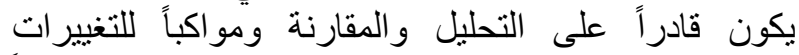

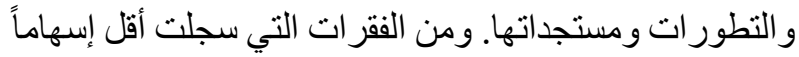

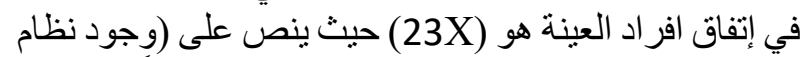
رقابة داخلية فعال في مكان العمل يؤثر إيجاباً في أداء

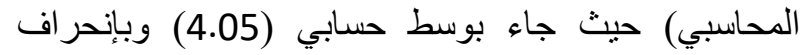

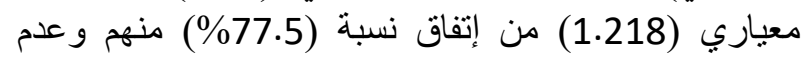
الاتفاق نسبة (12.5\%) منهم في حين نسية (10) (10\%) منهم اتخذوا موقف الحياد من هذه الفقرة.
المصدر: من إعداد الباحثين بالاعتماد على نتائج الحاسبة

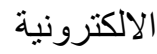

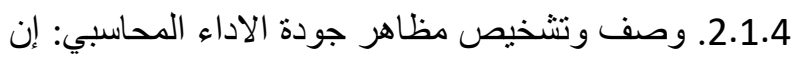

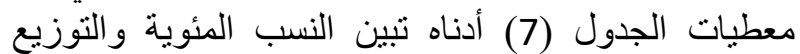

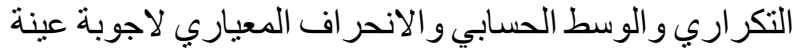

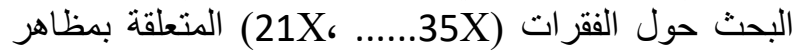
جودة الأداء المحاسبي حيث يلاحظ من إجاباتهم بأنها تميل النيل

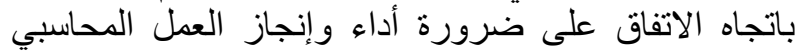

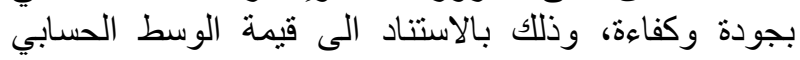

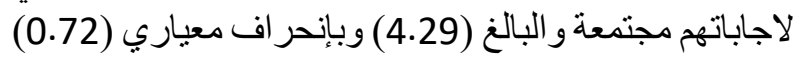

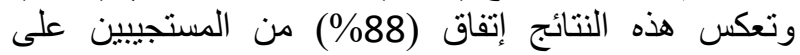

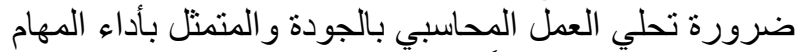

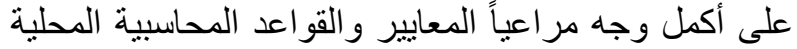
و الدولية وكذلك مر اعاة الانظمة و القو اتنين التي تحكم النشاط النيا

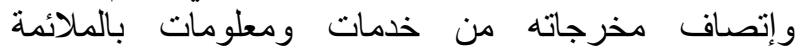
و الموثوقية و الحياد وتوفير ها في التوقيت المناسب. أما نسبة

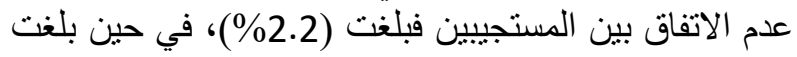

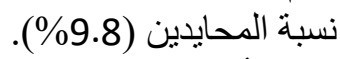
ومن أكثر المتغيرات التي أسهمت في تعزيز نسبة أتفاق المستجيبين على جودة الأداء المحاسبي هو (X21) الذي لئي يشير

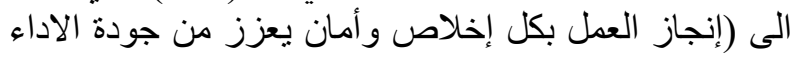
المحاسبي) حيث حقق أعلى وسط حسابي بقيمة (4.58)

\begin{tabular}{|c|c|c|c|c|c|c|c|c|c|c|c|c|}
\hline \multirow{2}{*}{ المعياري الانحر } & \multirow{2}{*}{ الحسابي } & \multicolumn{2}{|c|}{ لا أتفق بشدة } & \multicolumn{2}{|r|}{ لا أنفق } & \multicolumn{2}{|r|}{ محايد } & \multicolumn{2}{|r|}{ أتفق } & \multicolumn{2}{|c|}{ أتفق بشدة } & \multirow{2}{*}{ المتغير ات } \\
\hline & & $\%$ & التكرار & $\%$ & التكر ار & $\%$ & التكر ار & $\%$ & التكر ار & $\%$ & التكر ار & \\
\hline 0.636 & 4.58 & 0.0 & 0 & 0.0 & 0 & 7.5 & 3 & 27.5 & 11 & 65.0 & 26 & $x 21$ \\
\hline 0.714 & 4.45 & 0.0 & 0 & 2.5 & 1 & 5.0 & 2 & 37.5 & 15 & 55. & 22 & X22 \\
\hline 1.218 & 4.05 & 7.5 & 3 & 5.0 & 2 & 10.0 & 4 & 30.0 & 12 & 47.5 & 19 & $\times 23$ \\
\hline 0.823 & 4.30 & 0.0 & 0 & 2.5 & 1 & 15.0 & 6 & 32.5 & 13 & 50. & 20 & $\times 24$ \\
\hline 0.632 & 4.10 & 0.0 & 0 & 0.0 & 0 & 15.0 & 6 & 60.0 & 24 & 25. & 10 & $\times 25$ \\
\hline 0.549 & 4.43 & 0.0 & 0 & 0.0 & 0 & 2.5 & 1 & 52.5 & 21 & 45.6 & 18 & $\mathrm{X} 26$ \\
\hline
\end{tabular}




\begin{tabular}{|c|c|c|c|c|c|c|c|c|c|c|c|c|}
\hline 0.764 & 4.33 & 0.0 & 0 & 0.0 & 0 & 17.5 & 7 & 32.5 & 13 & 50.0 & 20 & $\times 27$ \\
\hline 0.770 & 4.15 & 0.0 & 0 & 2.5 & 1 & 15.0 & 6 & 47.5 & 19 & 35.0 & 14 & $\mathrm{X} 28$ \\
\hline 0.608 & 4.20 & 0.0 & 0 & 0.0 & 0 & 10.0 & 4 & 60.0 & 24 & 30.0 & 12 & $\times 29$ \\
\hline 0.927 & 4.25 & 0.0 & 0 & 7.5 & 3 & 10.0 & 4 & 32.5 & 13 & 50.0 & 20 & $\mathrm{X} 30$ \\
\hline 0.670 & 4.25 & 0.0 & 0 & 2.5 & 1 & 5.0 & 2 & 57.5 & 23 & 35.0 & 14 & X31 \\
\hline 0.616 & 4.33 & 0.0 & 0 & 0.0 & 0 & 7.5 & 3 & 52.5 & 21 & 40.0 & 16 & $\mathrm{X} 32$ \\
\hline 0.608 & 4.20 & 0.0 & 0 & 0.0 & 0 & 10.0 & 4 & 60.0 & 24 & 30.0 & 12 & X33 \\
\hline 0.707 & 4.25 & 0.0 & 0 & 0.0 & 0 & 15.0 & 6 & 45.0 & 18 & 40.0 & 16 & $\mathrm{X} 34$ \\
\hline 0.679 & 4.50 & 0.0 & 0 & 2.5 & 1 & 2.5 & 1 & 37.5 & 15 & 57.5 & 23 & X35 \\
\hline \multirow[t]{2}{*}{0.728} & \multirow[t]{2}{*}{4.29} & & 0.5 & & 1.7 & & 9.8 & & 44.3 & 43.7 & & المؤشر \\
\hline & & \multicolumn{4}{|c|}{2.2} & \multicolumn{2}{|c|}{9.8} & \multicolumn{4}{|c|}{88.0} & الكلي \\
\hline
\end{tabular}

المصدر: من إعداد الباحثين بالاعتماد على نتائج الحاسبة الالكترونية:

لمتغير ات البحث الرئيسية و التي (Pearson Correlation) هي المتغير المستقل ويمثل التعليم المحاسبي المستمر بأبعادها

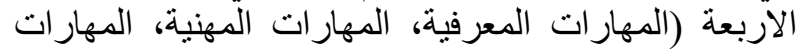

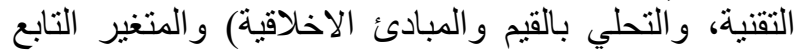

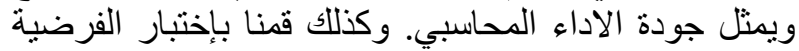
الاولى للبحث من خلال نتائج التحليل الموضحة في الجدول
2.4. إختبار أنموذج البحث وفرضياته:

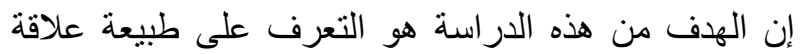

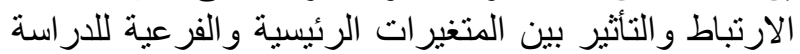
بهدف إختبار فرضياتها و التحقق من صحتها وذاتير اللك من خلال

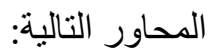

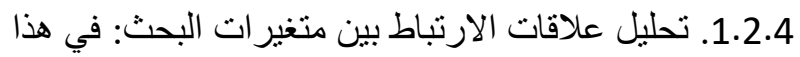

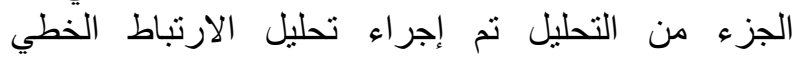

جدول رقم (8): علاقات الارتباط بين أبعاد التعليم المحاسبي المستمر ومظاهر جودة الأداء المحاسبي

\begin{tabular}{|c|c|c|c|c|c|}
\hline أبستمر مجتمعة التعليم & والمبادئي الاخلاقية بالقة. & الفنــــــارة & المهـــارة & المعرفيــاتة & المتغير التابع المتغير المستقل \\
\hline $0.824 * *$ & $0.855^{* *}$ & $0.432 * *$ & $0.590 * *$ & $0.551^{* *}$ & جودة الأداء المحاسبي \\
\hline $\mathrm{N}=40$ & & & & $0.01 ة$ & ـ معنوي عند مستو. \\
\hline
\end{tabular}

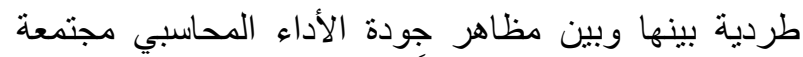
وبنسب متفاوتة وذللك استناداً الى قيم معاملاتهم الارتباطية

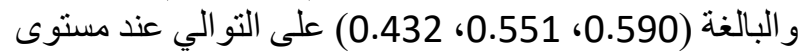

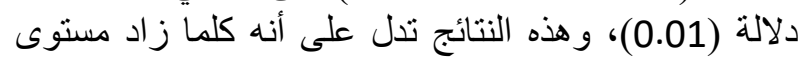

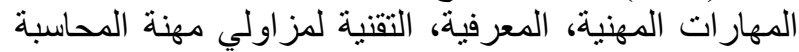

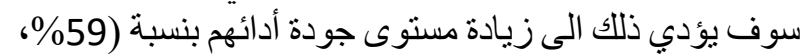

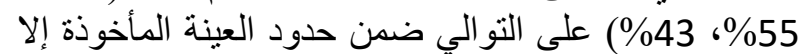

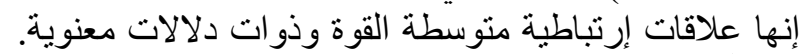

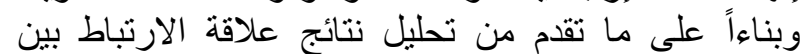

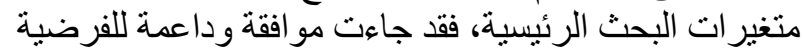

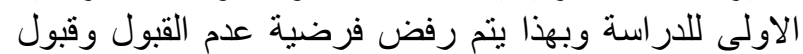

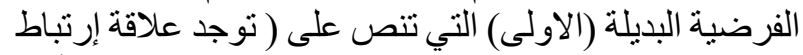

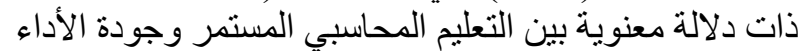

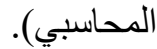
2.2.4. تحليل العلاقات التأثيرية بين متغير ات البحث: انطلاقاً

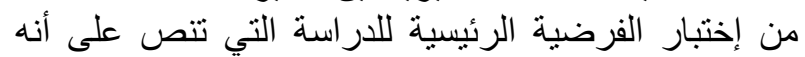

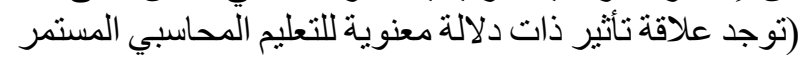

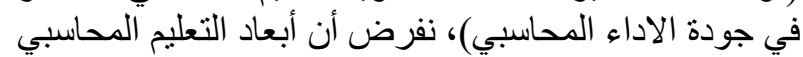

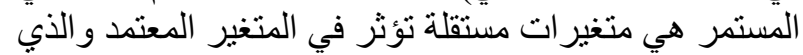

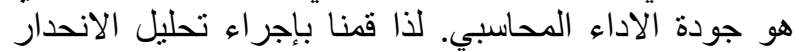

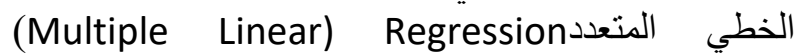

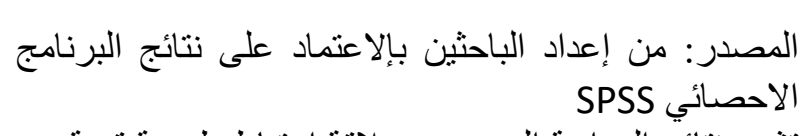

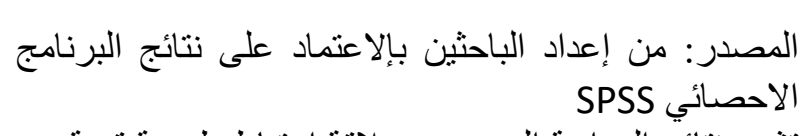

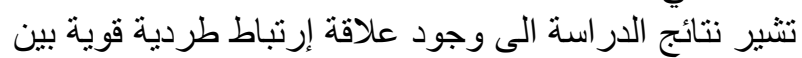

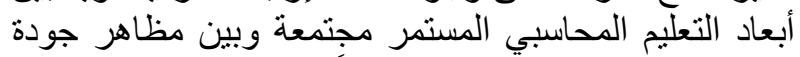

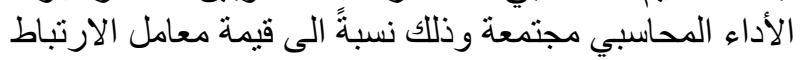

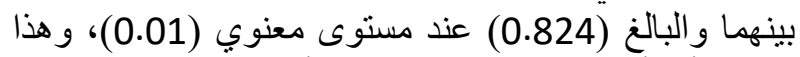
يفسر بأن أي زيادة (0.824) في مستويات أبعاد ألتعليم المحاسبي

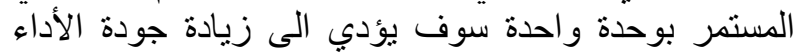

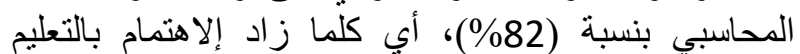

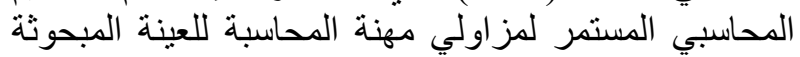

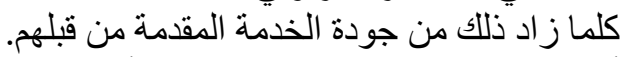

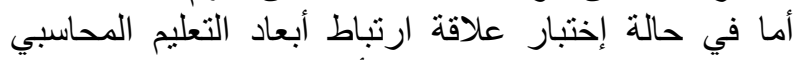

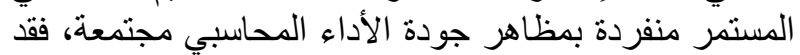
لوحظ وجود علاقات إرتباط طردية ذات دود دلاتلاتلات معنوية بينها

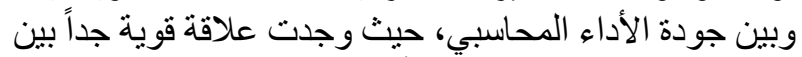

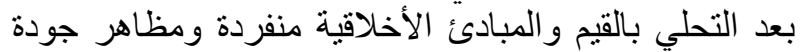

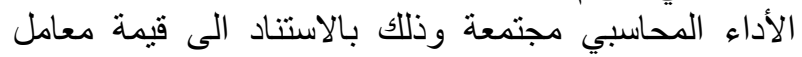

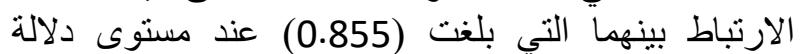

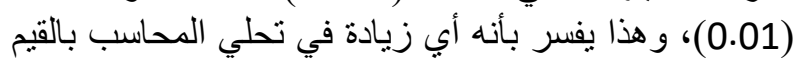

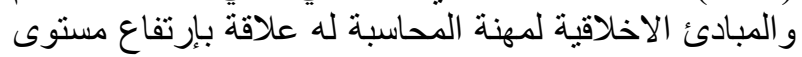
جودة أدائه المحاسبي بنسبة (85\%). أما بقية أبعاد التعليم المبادية

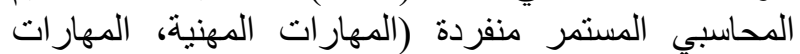
المعرفية، المهارات الفنية)، فقد لوحظ وجود علاقات إرتباط المباط 
وإختبار (F) للكثف عن مدى نتأثر جودة الأداء المحاسبي

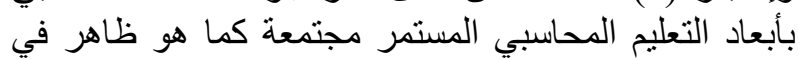
الجدول (9) أدناه، حيث يتبين من قيمة (R2) البالغة (0.788)

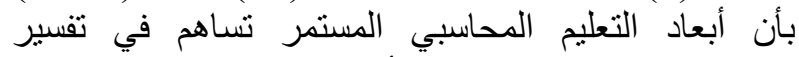

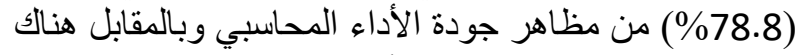

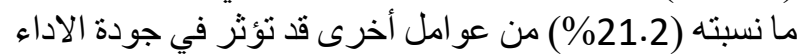

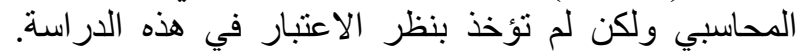

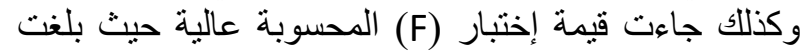

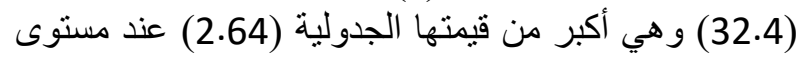

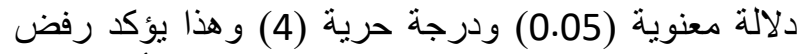

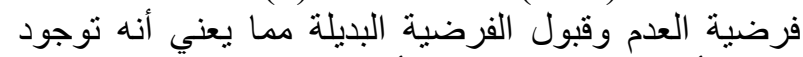

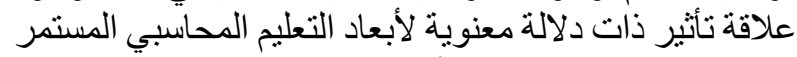
مجتمعة في مظاهر جودة الأداء المحاسبي مجتمعة.
للمتغيرات الاساسية للبحث وعليه نم تقدير النموذج التالي كمعادلة الانحدار الخطي المتعدد لمتغيرات البحث بالته بالثكل التالي: $Y_{i}=B_{0}+B_{1} X_{1}+B_{2} X_{2}+B_{3} X_{2}+B_{4} X_{4}$ حيث أن: جودة الاداء المحاسبي (المتغير

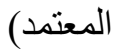

معاملات الانحدار الخطي المتعدد المتغيرات المستقلة (المهارات التهنة

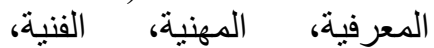
و التحلي بالقية،

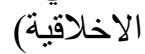

$B_{4}, B_{3}, B_{2}, B_{1}, B_{0}$ $X_{4}, X_{3}, X_{2}, X_{1}$

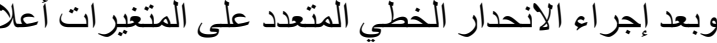

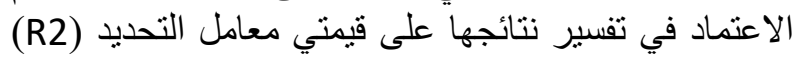

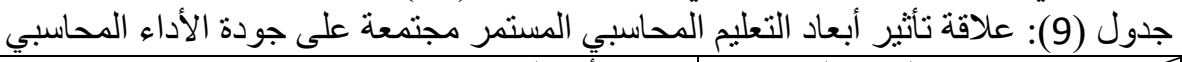

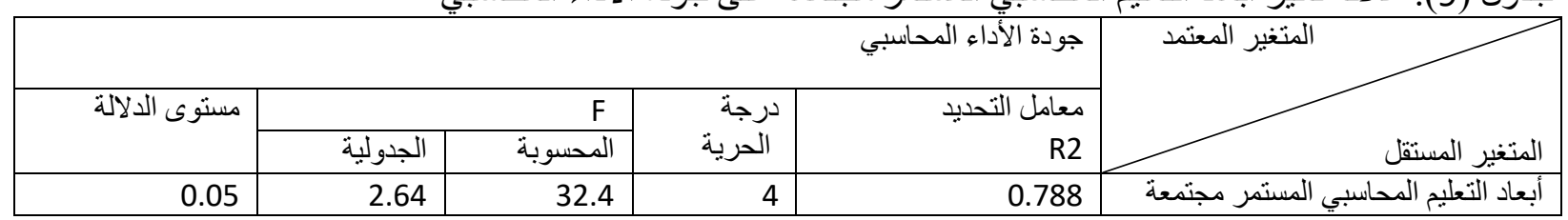

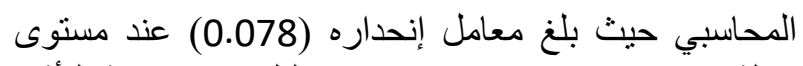

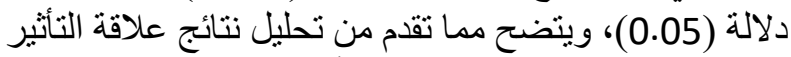

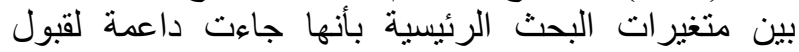

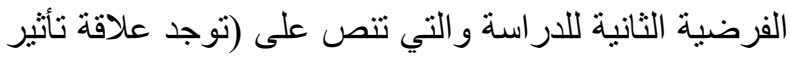
ذات دلالة معنوية للتعليم المحاسبي المستمر في جودة الادية الاداء

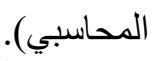

وفي هذا الجزء من التحليل أيضا تم تتخيص علاقة تأثير

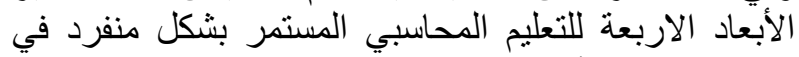
مظاهر جودة الأداء المحاسبي مجتمعة وذللك بإجراء الاء تحليل الانحدار الخطي البسيط (Simple Linear Regression) وكما في الجدول (10) أدناه.

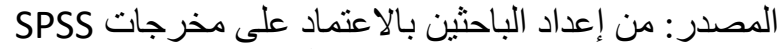

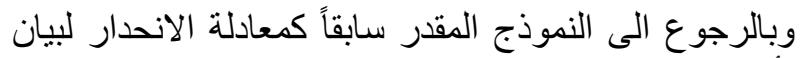

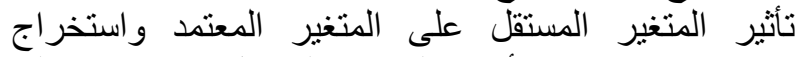
معاملات الانحدار لأبعاد المتغير المستقل بالإعنماد على المانى مخرجات SPSS فعليه ستكون المعادلة كالآتي:

$$
Y \mathfrak{i}=-0.947+0.129 \times 1+0.299 \times 2+
$$
$0.078 X 3+0.685 X 4$ يلاحظ من المعادلة أعلاه بأن بعد التحلي بالقيم والمبادئ

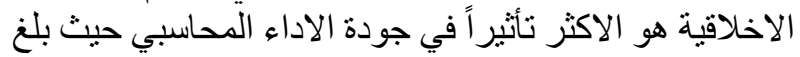

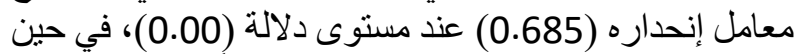
بعد المهار ات التقنية كان من بين الاقل تأثير آ في جودة الاداء

جدول (10):علاقة تأثثر أبعاد التعليم المحاسبي المستمر منفردة في جودة الأداء المحاسبي

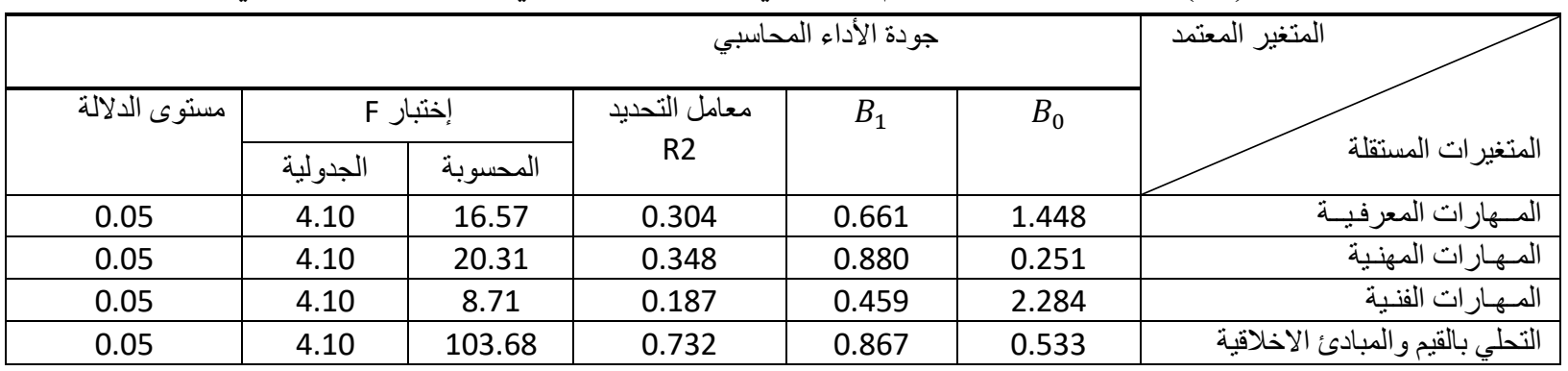

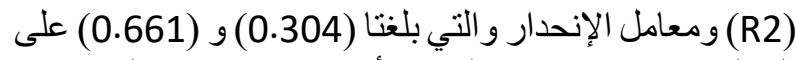

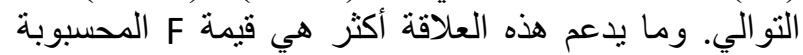

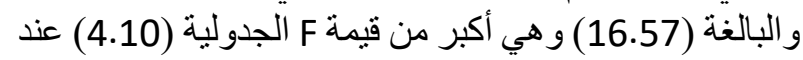

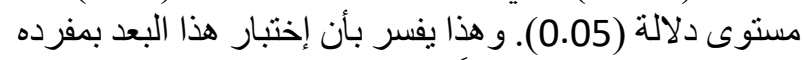
كمتغير مستقل يؤثر ايجاباً في جودة الاداء المأ المحاسبي وبنسبة البدية
المصدر : من إعداد الباحثين بالاعتماد على مخرجات SPSS.

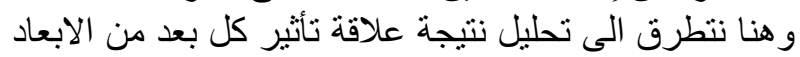

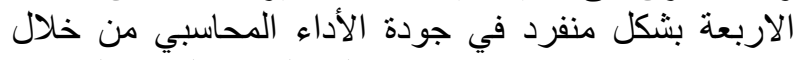

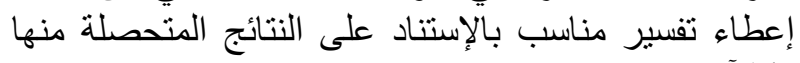
وكالآتي: 1. وجود علاقة تأثير معنوي إيجابي لبعد المهارات المعرفية

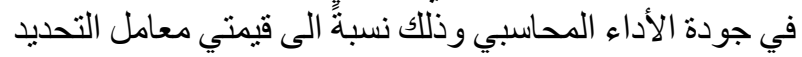


وفاعلية الاداء مما ينعكس بدوره على جودة الاداء

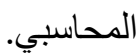

تنطوي مهنة المحاسبة على مبادئ وقيم اخلاقية تمثل الإئل

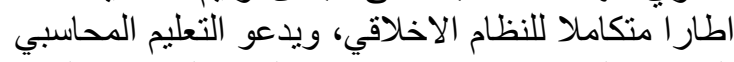

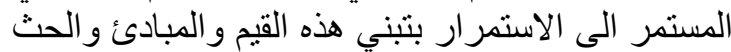
على أهميتها في الممارسة المهنية.

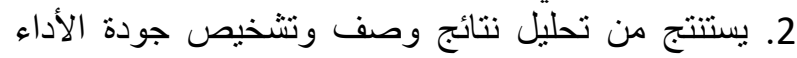

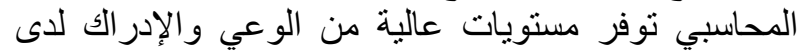
المستجييين بأهية تو افر الجودة والكفاءة في الأداء المحاسبي

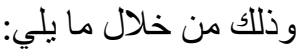
ضرورة الإلنزام بمعايير التعليم المحاسبية الدولية

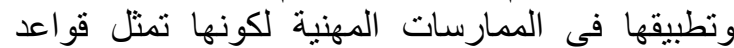
أساسية تزيد من فاعلية الأداء المحاسبي.

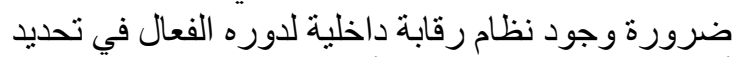

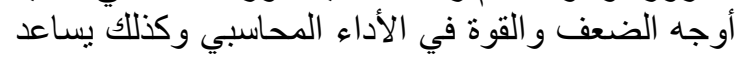

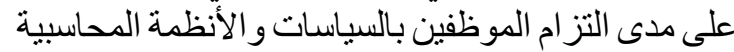
بما يعكس على جودة الأداء المحاسبي.

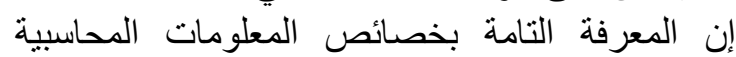
لممارسي المهنة يضفي على أدائهم جودة وفاعلية الماعلية.

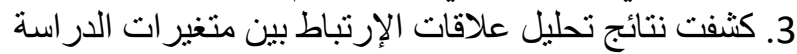

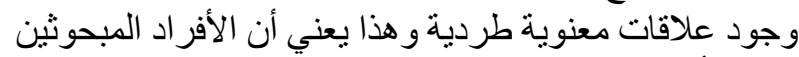

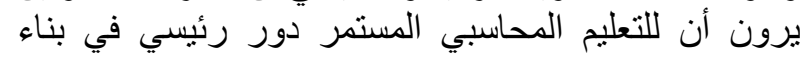

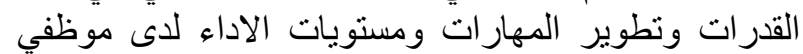

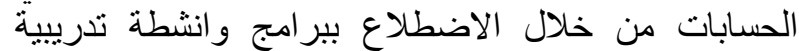
و استعر اض معايير الجودة في الاداء الإحاسبي. لإني.

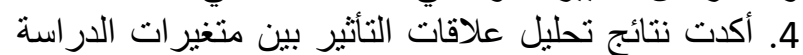

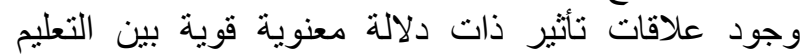

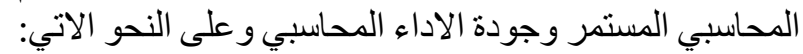

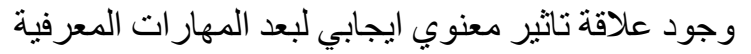

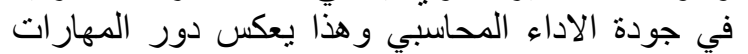
المعرفية في تدعيم جودة الاداء المادي الماسبي.

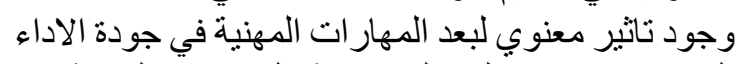

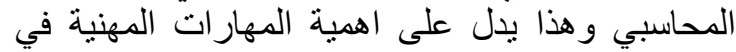
تعزيز و تحسين جودة الادير بداء المحاسبي.

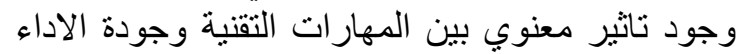

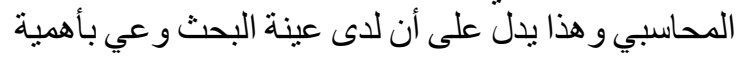

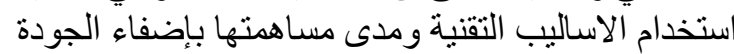

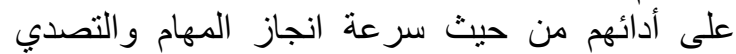
ل لمشاكل العمل بأقل جهود ممكنة.

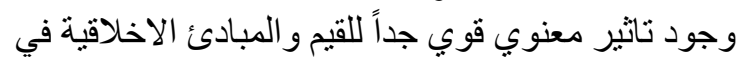

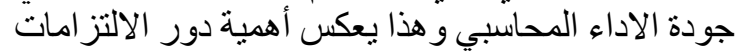
الاخلاقية في تعزيز جودة الاداء المحاسبي.

1. الاهتمام من قبل ادارة الجامعة باستحداث دور ات تدريبية

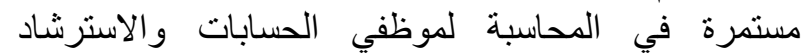

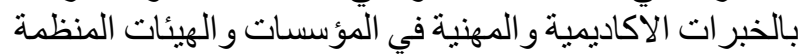

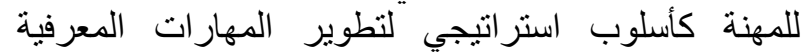
و المهنية لموظفي الحسابات.

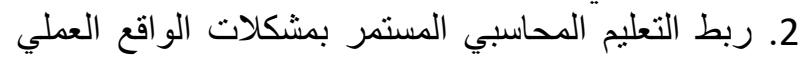

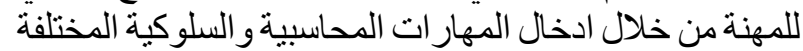

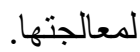

أكبر في حالة دمجه مع الابعاد الاخرى للمتغير المستقل حيث كان معامل إنحداره (0.129).

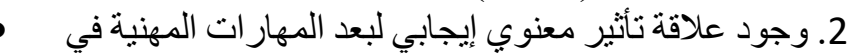

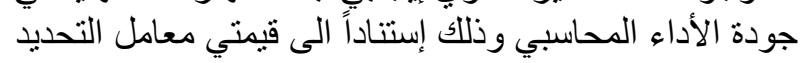

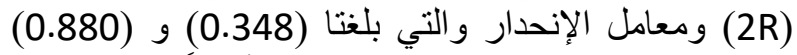

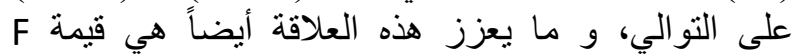

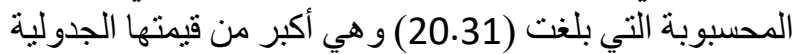

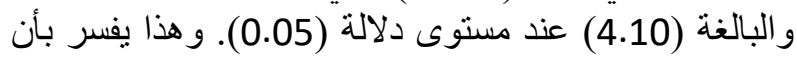

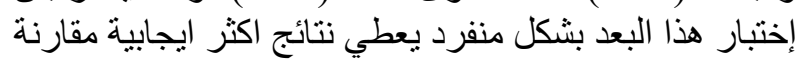

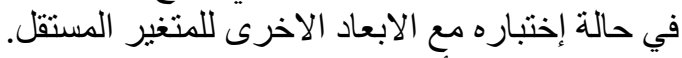

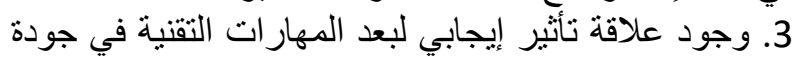

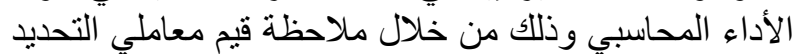

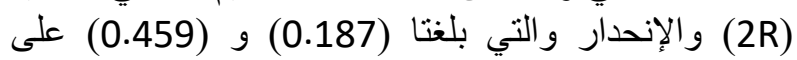
التو الي، وكذلك يلاحظ بأن قيمة FR المحسوبة (2R) (8.71) هي أكبر

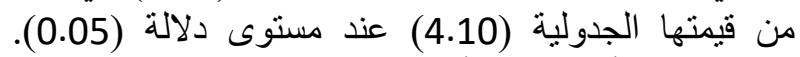

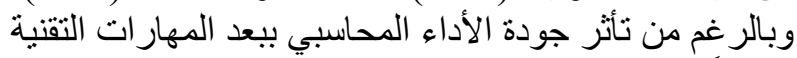

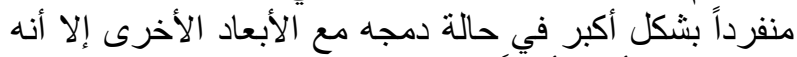

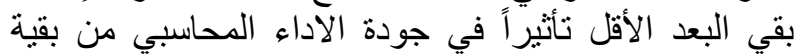

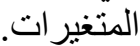
4. وجود علاقة تأثثر معنوي إيجابي قوية جداً لبعد التحلي

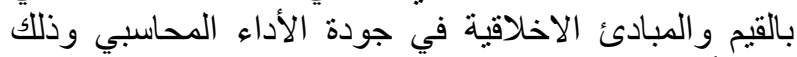

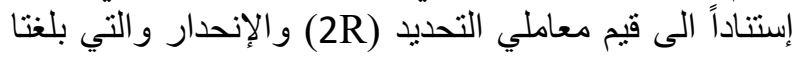

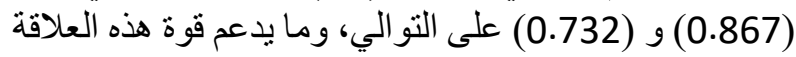

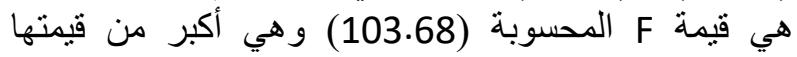

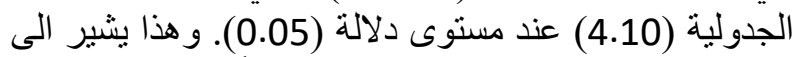

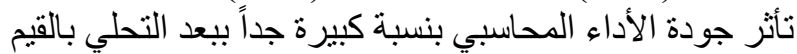

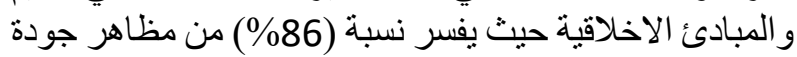
الأداء المحاسبي. من خلال ما سبقي، يتبين بأن لكل بعد من الابعاد الاربعة للتعليم

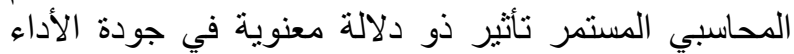

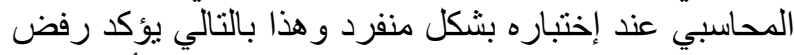

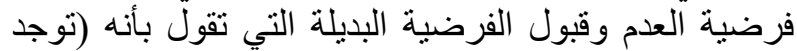

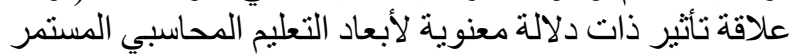
في تعزيز جودة الاداء المحاسبي). 5. الاستتناجات و التوصيات

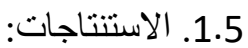

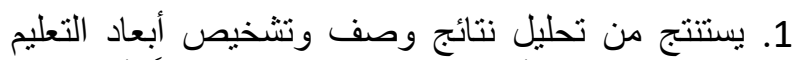

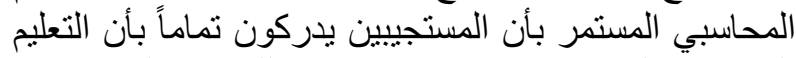

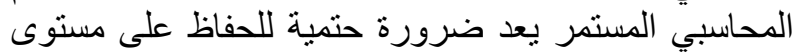
جودة الاداء المحاسبي في ظل بيئة تتسم بالديناميكية المستمرة التئية فظلا عن منطلبات سوق العمل و على النحو النالي:

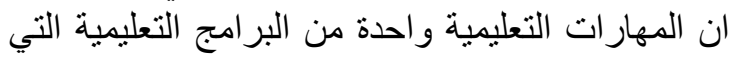

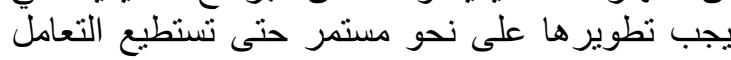

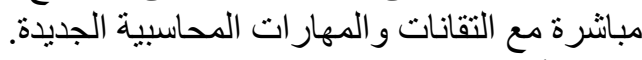

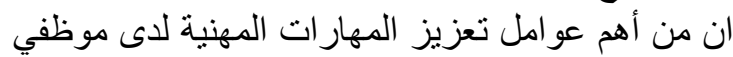

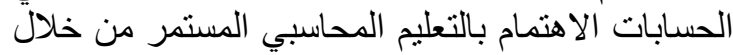

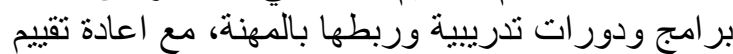
القابليات و المؤهلات المهنية.

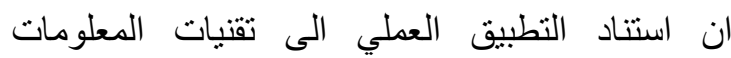
التكنلوجية و المز ايا التي تقدمها له الاثر الكبير على كفاءة التعات 
التجارية و علوم التسيىر، جامعة محمد خضير، الجز ائر.

بوعزرية، هجيرة، ولندار، نبيلة. (2017). واقع التعليم

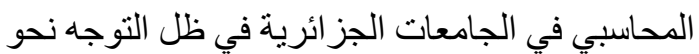

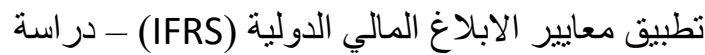

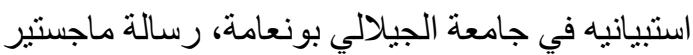
منشورة في اختصاص العلوم المالية والمصرفية، جامعة الجيلالي بونعامة، كلية العلوم الاقتصادية و التجارية و علوم التيسير، الجز ائر. الجليلي، مقداد احمد، وذنون، الاء عبد الواحد. (2010). استخدام معابير التعليم الدولية للمحاسبين المهنيين في

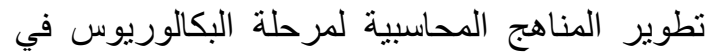

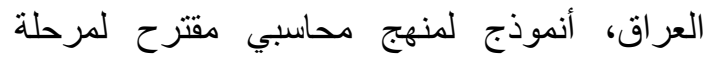
البكالوريوس في العراق، ملة تنمية الرافدين،

256-235، (99)32

الجو هر، كريمة علي كاظم. (2011). العلاقة بين الخصائص النو عية للمعلومات المحاسبية وقو اعد الحوكمة لمجلس الادارة، دراسة تحليلية لوجهات نظر المحاسبين

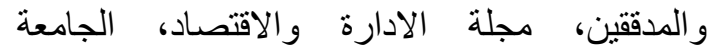
المستتصرية، العدد 90، 103-128.

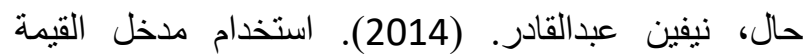
الاقتصادية المضافة في تقييم الأداء للشركات، رسالة. ماجستير في اختصاص المحاسبة، كلية التجارة، جامعة بورسعيد، مصر.

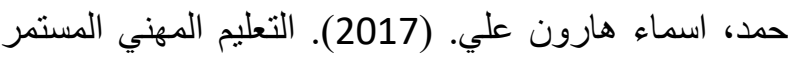
للمر اجع الخارجي ودوره في جودة التقارير المالية، در اسة ميدانية على ديوان المر اجعة القومي ودوردي وكاتب

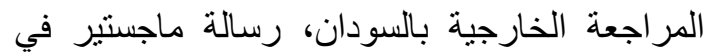

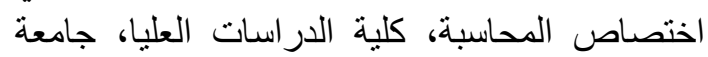

$$
\text { النيلين، السودان. }
$$

حميدي، زينب عباس. (2009). الخصائص النوعية

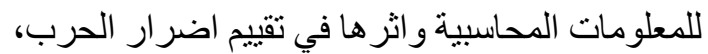
در اسة ميدانية في الثركة العامة لصناعة البطاريات، مجلة الادارة و الاقتصاد، جامعة بغداد، العدد 75، 37-

.54

الز املي، علي عبد الحسين. (2014). التعليم المحاسبي ودوره في تطوير المهار ات المهنية لخريجي قسم المحاسبة. دراسة استطلاعية لآراء عينة من اعضاء هئ هيئة

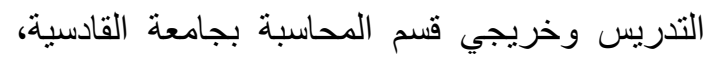
مجلة الادارة والاقتصاد، جامعة القادسية، المجلد الثالث، 312(12)، 312-286.

زهير ، شلال،(2014) ، افاق اصلاح نظام المحاسبة العمومية

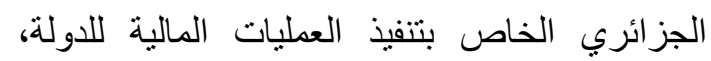
اطروحة دكتور اه منشورة غي علوم التيسيير، جامعة
3. اعادة تقييم القابليات و المهار ات المهنية قبل وبعد بر امج التعليم المحاسبي المستمر للوقوف على مدى كفاءة وفعالية

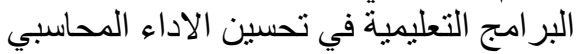

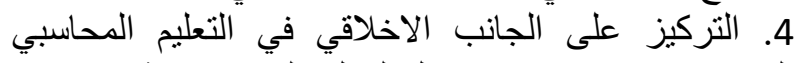

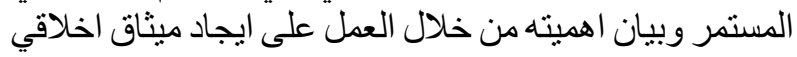

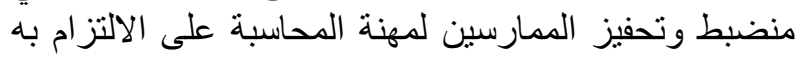
كسلوك مهني دائم.

5. ضرورة التوسع في اعداد الدراسات والبحوث المستقبلية

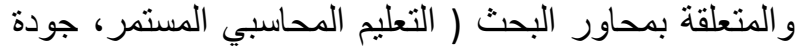

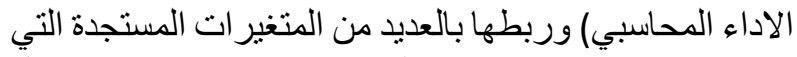
تؤثر في مستوى اداء موظفي الحسابات في نطاق بيئة الاعمال و مستجداتها. 6. التركيز على النتائج التي توصل اليها الباحثان وحث جميع

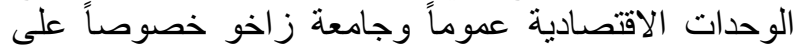

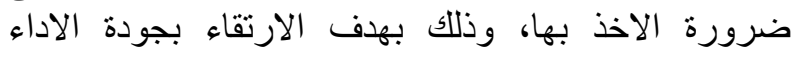
المحاسبي لدى موظفيها.

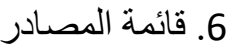

1.6. المصادر العربية:

أبو حطب، موسى محمد. (2009). فاعلية نظام تقييم الاداء

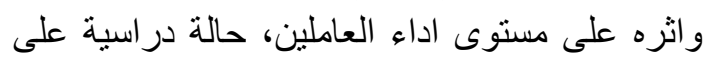

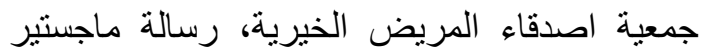
منشورة، كلية التجارة، الجامعة الاسلامية، غزة الهرة

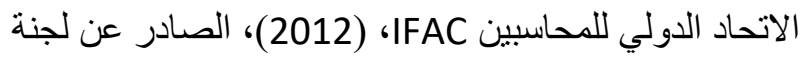
التعليم للاتحاد الدولي للمحاسبين ، ترجمة جمعية

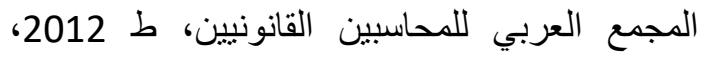
المكتبة الوطنية، عمان، الاردن. البديري، حسين جميل غافل. (2017). اثر جودة المعلومات المحاسبية في القوائم المالية على قرار ات مستخدميها دراسة تطبيقية في مجموعة من الثركات العراقية،

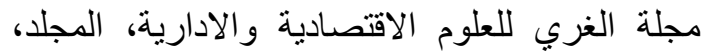

بن صالح، عبد الله. (2017). اهمية تطوير التعليم المحاسبي في ضوء مستجدات معايير الابلاغ المالي الدولية ودورها في تحرير الخدمات المحاسبية في الدول العربية، اطروحة دكتوراه في علوم التسيير، كلية

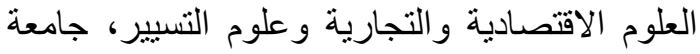
حسيبة بن علي بالثلف، الجزائر.

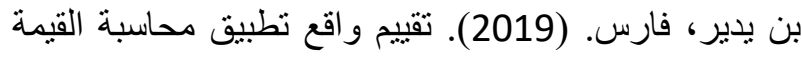

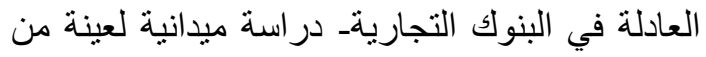

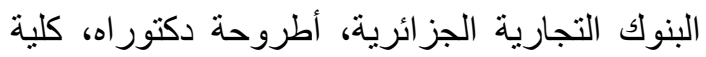

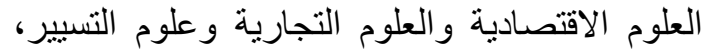
جامعة قاصدي مرباح، الجزائر.

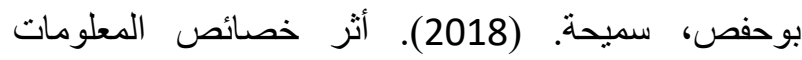
المحاسبية في اتخاذ القرارات المالية في المؤسسات التهات الاقتصادية الجزائرية "دراسة حالة: مجموعة من النابه المؤسسات الاقتصادية"، كلية العلوم الاقتصادية و 
الاقتصاد و العلوم الاجتماعية، نحو رؤيا شاملة لتعزيز البنية التحتية الاقتصادية في فلسطين، فلسطين.

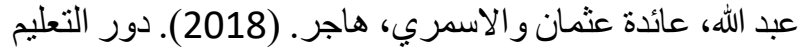

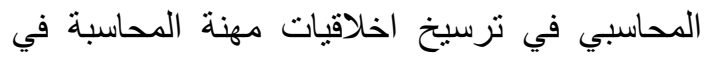

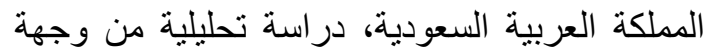
نظر موظفي الادارة المالية في شركة خالد عفير وشريكه محاسبون ومر اجعون قانونيون، مجلة الطريق الطيق التربوي، 5 (3)، المملكة العربية السعودية.

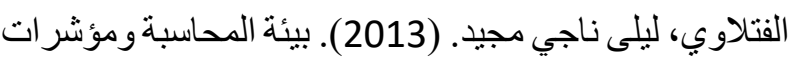
تكيفها لتكنولوجيا المعلومات، مجلة كلية بغداد للعلوم

الاقتصادية الجامعة، العدد (4)، 283-302.

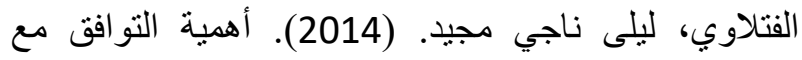

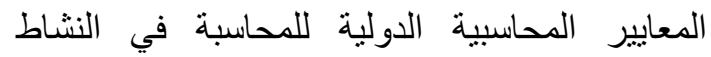

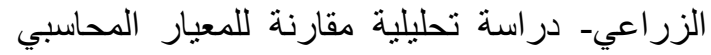
الدولي رقم (41) و القاعدة المحاسبية رقم (11)، مجلة لمبلة القادسية للعلوم الادارية و الاقتصادية، 16(2)، 185-

201

القو اعد العامة للتعليم المهني المستمر . (2003). الصادرة عن

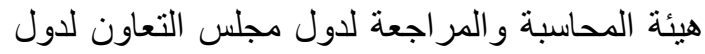
الخليج العربية. كاملية، بن شلوية، و امال، شرفي. (2013). الجودة كمدخل لتحسين الاداء الانتاجي في المؤسسات العموميةـ

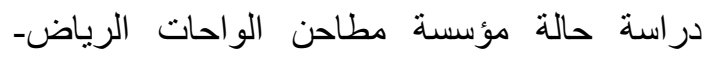
سطيفـ تقرت، رسالة ماجستير في علوم التسيير، كلية

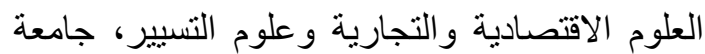

$$
\text { قاصدي مرباح- ورقلة، الجزائر. }
$$

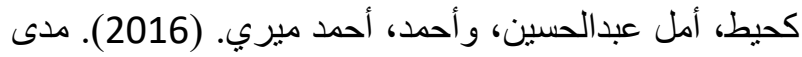

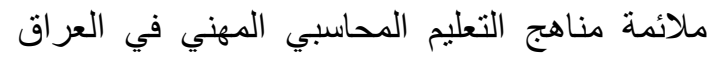

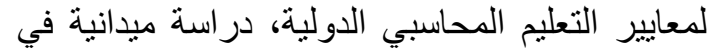

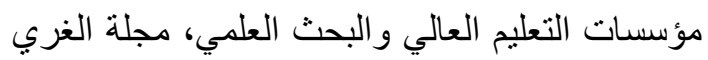
للعلوم الاقتصادية والادارية، 13(39)، 349-380.

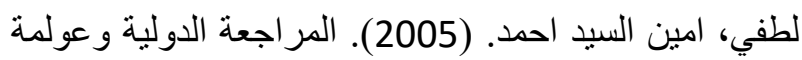

اسو اق راس المال، ط1، الدار الجامعية، القاهرة.

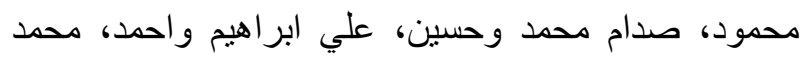
حامد. (2011). اثر المعايير الاخلاقية للمحاسب الهابن

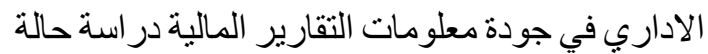

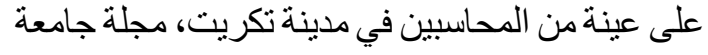
الانبار للعلوم الاقتصادية والادارية، 4 (7)، 403-

$$
.430
$$

مدو خ، خيام محمد كامل. (2014). و اقع تطور مهنة المحاسبة

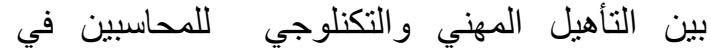
الثركات العاملة في قطاع غزة، رسالة ماجستير في في التئي

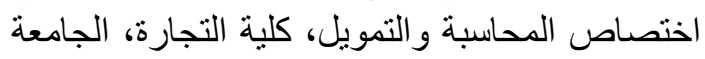

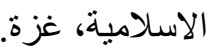

محمد بوقرة، كلية العلوم الاقتصادية والتجارية وعلوم التيسيير ، الجز ائر. سعيد، لقمان محمد. (2008). ادوات تكنلوجيا المعلومات الترات

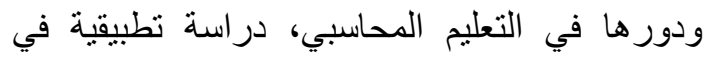

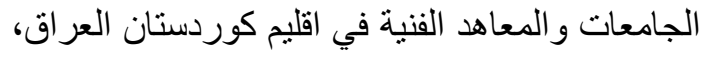

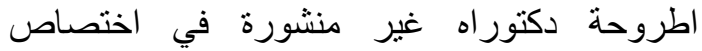

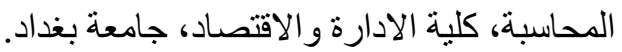
السقا، زياد هاشم و الحمداني، خليل ابر اهيم. (2012). دور

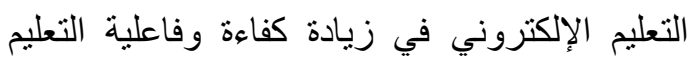

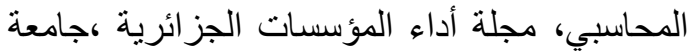
ورقلة، الجزائر، العدد (2). سليم، كحيل. (2015). دور الرقابة الداخلية في تحسين الاداء

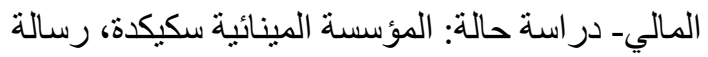
ماجستير منشورة في اختصاص العلوم المالية

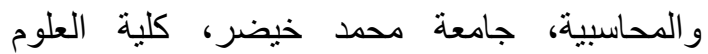
الاقتصادية و التجارية و علوم التيسيير ، الجز ائر.

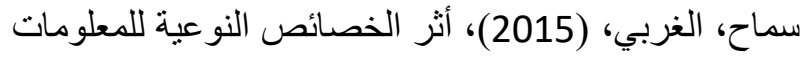

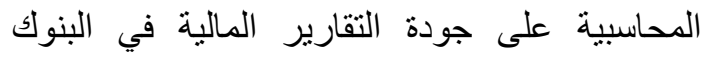

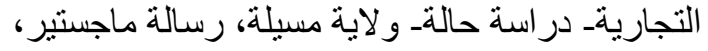

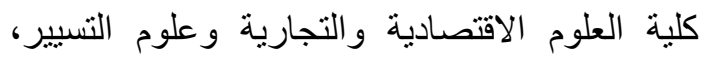
جامعة محمد بوضياف الوسيلة، الجز ائر.

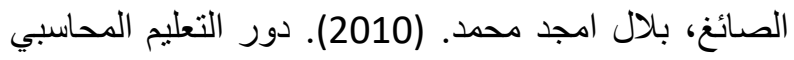

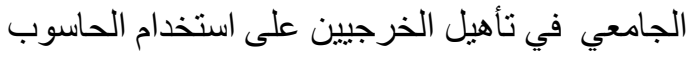
في العمل المحاسبي، الو اقع و إمكانية التطوير بالتطبيق التيق التيقي في محافظة نينوى، مجلة تكريت للعلوم الادارية اللعانية

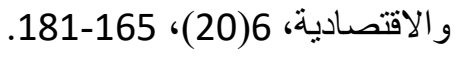

صوشة، ماريا علي. (2018). المسار التعلمي لممتهني المحاسبة و المر اجعة في ظل متطلبات معايير التعليم

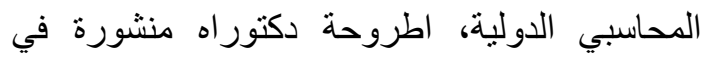
العلوم التجارية، جامعة محمد بوضياف المسيلة، كلية

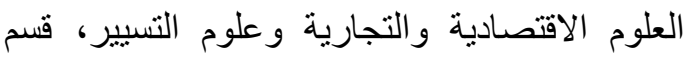

$$
\text { العلوم التجارية، الجزائر. }
$$

طه، الاء عبد الواحد ذنون. (2007). تطوير مناهج قسم الجزأن المحاسبة لكلية الادارة و الاقتصاد في جامعة الموصل

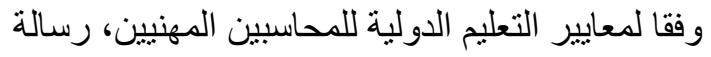

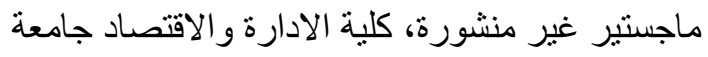

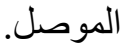

طه، محمد المعتز المجتبي ابراهيم، والماوري، ياسر احمد.

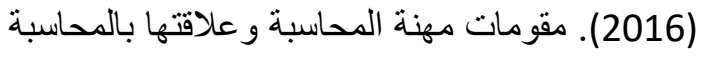
الإبداعية في الدول العربية، دراسة استطلاعية على بلى الإنى المهنيين و الأكاديميين في اليمن، مجلة الاندلس للعلوم

الانسانية و الاجتماعية، 3(12).

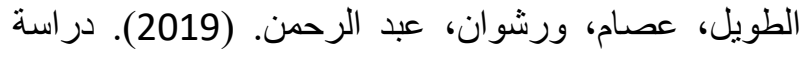
وتحليل واقع التأهيل المهني المحاسبي بهدف تهني تعزيز التنمية الاقتصادية، المؤتمر الثاني المحكم لكلية 
https://www.iasj.net/iasj?func=fulltext\& ald $=163881$

Hall, James A. (2011). Information Technology Auditing and Assurance. $3^{\text {rd }}$ ed. Australia, South-Western, Cengage Learning.

Howieson, Bryan. G. (2003). Accounting Practice in the New Millennium: Is Accounting Education Reading to meet the Challenge? The British Accounting Review, 35(2), 69-103.

International Accounting Education Standards Board, (2014), Handbook of International Education Pronouncements, http://www.ifac.org/Education/

International Federation of Accountants, (2015). Handbook of International Education Pronouncements. https://www.iaesb.org/publications/201 5-handbook-international-educationpronouncements-7

International Federation of Accountants, Establishing and Developing a Professional Accountancy Body. (2007). $2^{\text {nd }}$ Ed. Translated by Saudi Organization for Certified Public Accountants (SOCPA) www.ifac.org.

International Federation of Accountants, IFAC Education Committee Meeting Stockholm, August 2004. http://docplayer.net/12695272-Ifaceducation-committee-meeting-agenda-

8-d-stockholm-august-2004.html

International Federation of Accounting, (2003), Report of Accounting Education and Professional Skills, Education Committee, New York, http://www.ifac.org.

Introduction to international education standards. (2013).

https://www.ifac.org/system/files/publi cations/files/introduction-tointernation.pdf

Kaspina, Rosa. (2014). Continuing Professional Development of Accounting and Auditing: Russian Experience and
مطر ، محمد، ونور، عبد الناصر ، والرمحي، نضال. (2015).

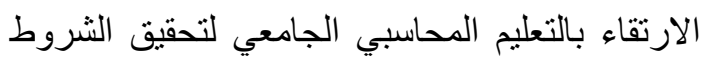

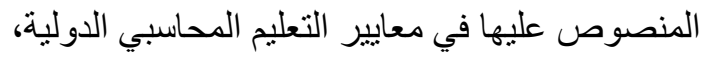

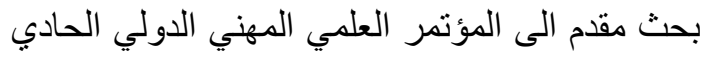

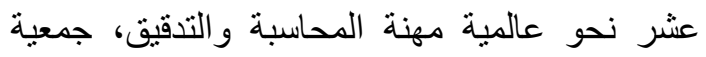
المحاسبين القانونيين الاردنيين، عمان الاردن 9-10

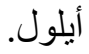
معايير التعليم الدولية للمحاسبين المهنيين (2003)، الصادرة عن لجنة التعليم للاتحاد الدولي للمحاسبين.

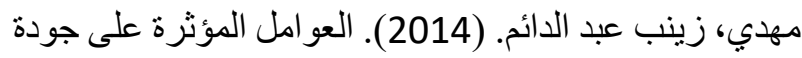

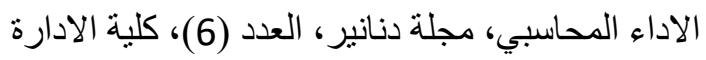
و الاقتصاد، الجامعة العر اقية.

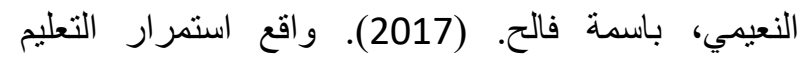

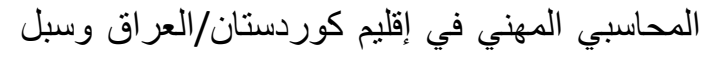

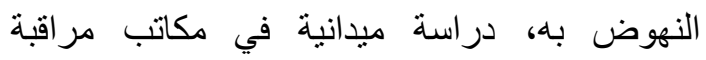

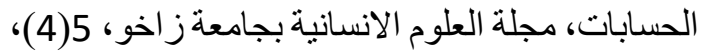
.1153-1167

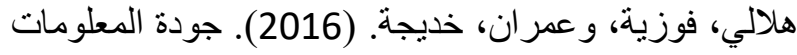

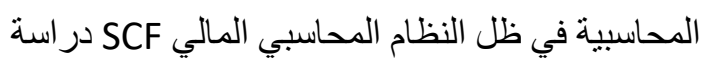

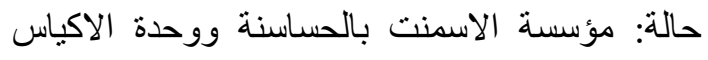

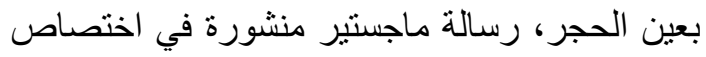

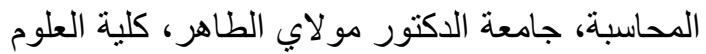

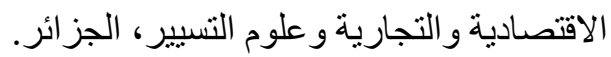

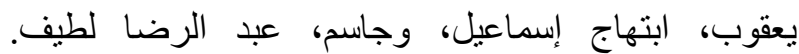
(2018). اختبار اثر التحول إلى معايير التقارير المالية

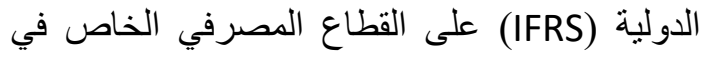
البيئة العر اقية من منظور نوعي وقيمي، الإلية مجلة الإدارة والاقتصاد، الجامعة المستتصرية، العدد (114)، .221-208

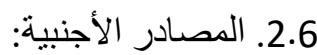

Arens, Alvin. A., Elder, Randal, J., and Beasley, Mark. S., (2012). Auditing and Assurance Services: an Integrated Approach. $14^{\text {th }}$ ed. Upper Saddle River, N.J. USA: Pearson prentice Hall.

Continuing Professional Education Committee. (2011). Instructions for Completing the continuing Professional Education (CPE) Sponsor's Application, New York.

Elshaer, Ibrahim, (2012). What is the Meaning of Quality? Suez Canal University, Management department, Egypt, Retrieved from 
Development of Accounting Education. International Journal of Education Quality, 23(4), 239-265.

Munteanu, Victor. (2007). Quality Control and Performance in Accounting, The Romanian- American University, Bucharest, www.oeconomica.uab
Challenges. Procedia-Social and Bevavioral Sciences, 191, 550-553.

Kieso, Donald E., Weygandt, Jerry J. and Warfield, Terry D. (2007). Intermediate Accounting. $12^{\text {th }}$ ed. NY, USA, John wiley and sons Inc.

Korne, Dirk F., Custers, Thomas S., Ethar, V. \& Klazinga, Neik S. (2009). 
الملاحق

$$
\begin{aligned}
& \text { جامعة زاخو } \\
& \text { كلية الإدارة والاقتصاد }
\end{aligned}
$$

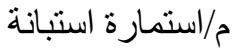

$$
\begin{aligned}
& \text { الأخت الفاضلة/ الأخ الفاضل: تحية طيبة..... } \\
& \text { السلام عليكم ورحمة الله وبركاته. }
\end{aligned}
$$

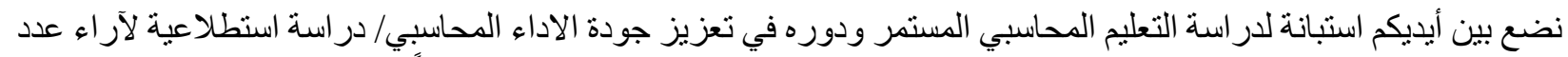

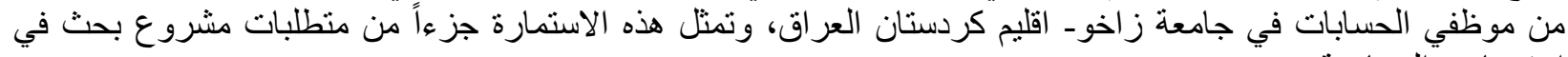
إختصاص المحاسبة. وتعدد مشار كتكم في تقديم المعلومات الكافية و المطلوبة بدقة وموضو عية تقييماً أفضل لموضوع البحث. وبالتالي مساعدة الباحثان في تحقيق أهداف ألبحث. تُخئ.

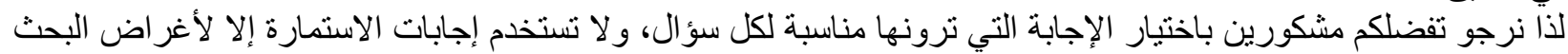

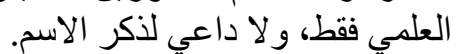
شاكرين تعاونكم معنا

كوفان محي الدين علي كودان

$$
\text { ايمان عبد الكريم العبادي }
$$

أو لاًا: معلومات عامة الرجاء وضع إثـارة( ل ل) في البديل المناسب لكل عبارة من العبار ات التالية :
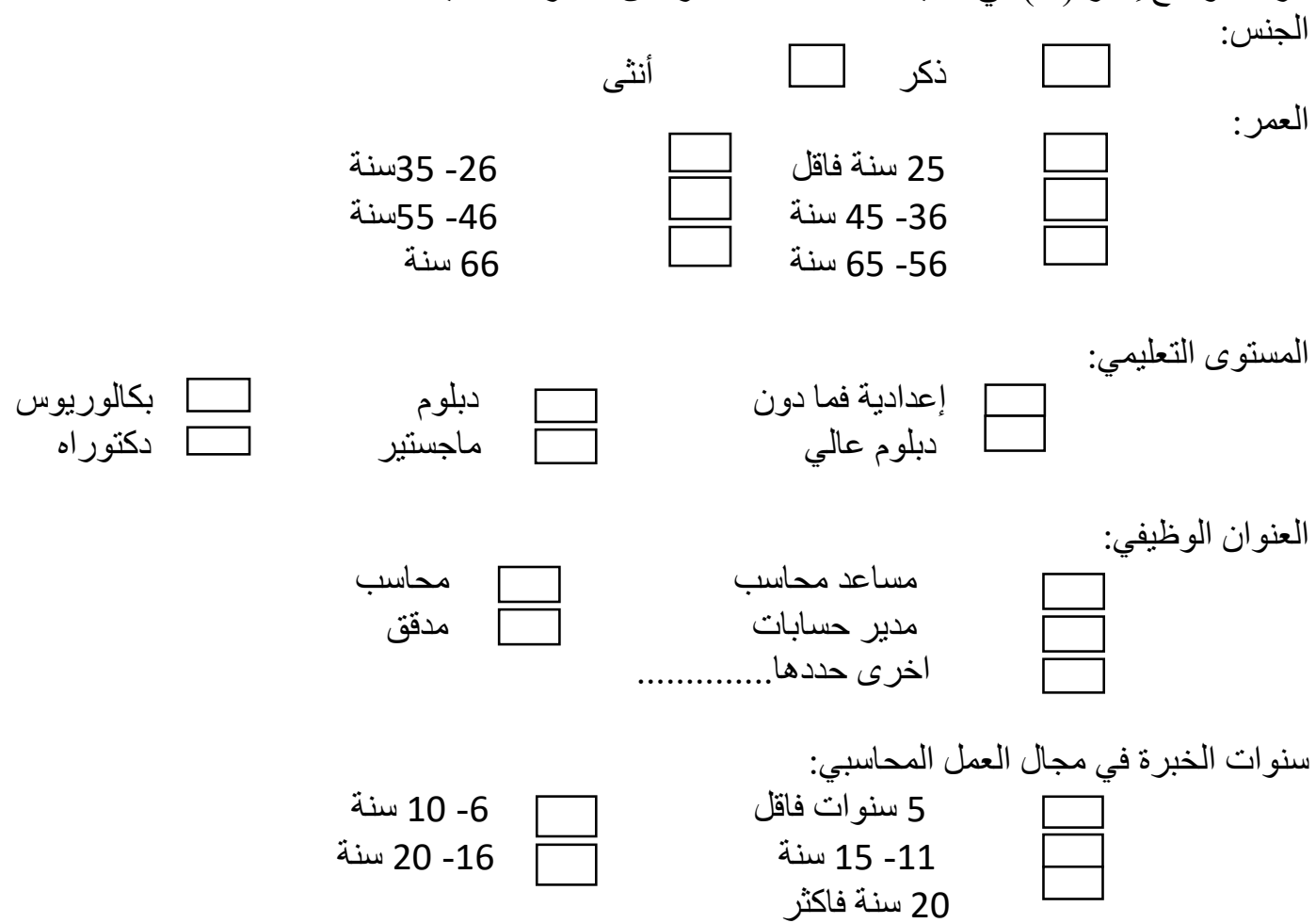

عدد الدور ات التدريبية التي التحقت بها في مجال المحاسبة خلال الثناث سنو ات الماضية:

$$
\begin{aligned}
& \text { من } 4 \text { - } 6 \text { دورة } \\
& 9 \text { دور ات فاكثر } 6 \text { دردة }
\end{aligned}
$$

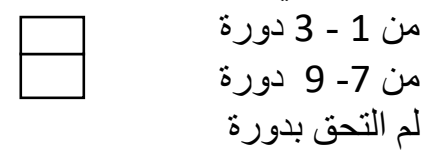

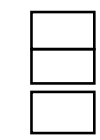




\begin{tabular}{|c|c|c|c|c|c|c|}
\hline لا لا اتفق & V & محايد & اتفق & اتفق & المتغيــــرات & $ت$ \\
\hline & & & & & لأول: ( التعليم المحاسبي المستمر ). & 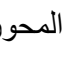 \\
\hline & & & & & لمعرفية (التعليم الاولي و الالمام بالمعايير المهنية ومستجداتها). & أ. مهار \\
\hline & & & & & تنمية المهار ات المعرفية تساعد في التفكير المنطقي و التحليل الذهني السليح. & -1 \\
\hline & & & & & المنلاحسينة. المستمر للمهارات المعرفية تساعد في تقبل بيئة العمل المتغيرة ومواكبة مستجداتها & -2 \\
\hline & & & & & تحسين المهارات المعرفية يساعد في معالجة مشاكل العمل المختلفة. & -3 \\
\hline & & & & & التطلع الى اهم التطورات والمستجدات التي تطر ا على مهنة المحاسبة من مبادئ ومعايير والعمل & -4 \\
\hline & & & & & مجال العمل النشرات والارشبادات التي تقرها المنظمات المهنية المحاسبية والاستفادة من توصياتها في & -5 \\
\hline & & & & & ات مهنية (التنديب والخبرة المهنية). & بـ مـ \\
\hline & & & & & المشاركة في الدورات التندرييية يحسن مستوى الاداء المحاسبي. & -6 \\
\hline & & & & & يسهم التدريب المهني المستمر في تطوير المهارات الدحاسبية. & -7 \\
\hline & & & & & يسهم التدريب المهني في اكساب خبرة مناسبة لممارسة العمل بنجاح. & -8 \\
\hline & & & & & البر امج التنرييية المستمرة تساهم في تحسين مستوى الاداء المحاسبي. & -9 \\
\hline & & & & & الخبرة المحاسبية تساعد في معالجة مشاكل العمل بطريقة مميزة. & -10 \\
\hline \multicolumn{7}{|c|}{ | ج- مهارات تقنية (الكترونية). } \\
\hline & & & & & بمهارة. التعرف على كيفية عمل انظمة المعلومات التقنية الحديثة والموجودة في مكان العمل لاستخدامها & -11 \\
\hline & & & & & المشاركة في الدورات التنرييية في مجال تكنلوجيا المعلومات يعزز مستوى الاداء المحاسبي. & -12 \\
\hline & & & & & امتلاك المهارات و المؤهلات الكافية في مجال تكنلوجيا المعلومات يساعد في تحسين مستوى الاداء & -13 \\
\hline & & & & & استخدام التكنلوجيا في العمل المحاسبي يساعد في تخفيف الاعباء الدحاسبية. & -14 \\
\hline & & & & & استخدام التكنلوجيا في مهنة المحاسبة يساعد في سر عة انجاز العمل وبكفاءة. & -15 \\
\hline
\end{tabular}


كودان، كوثان محي الدين و العبادي، إيمان عبد الكريج / مجلة العلوم الانسانية لجامعة زاخو، مجلد:8 ، العدد:2 ، ص 242- 265 ، خزيران- 2020.

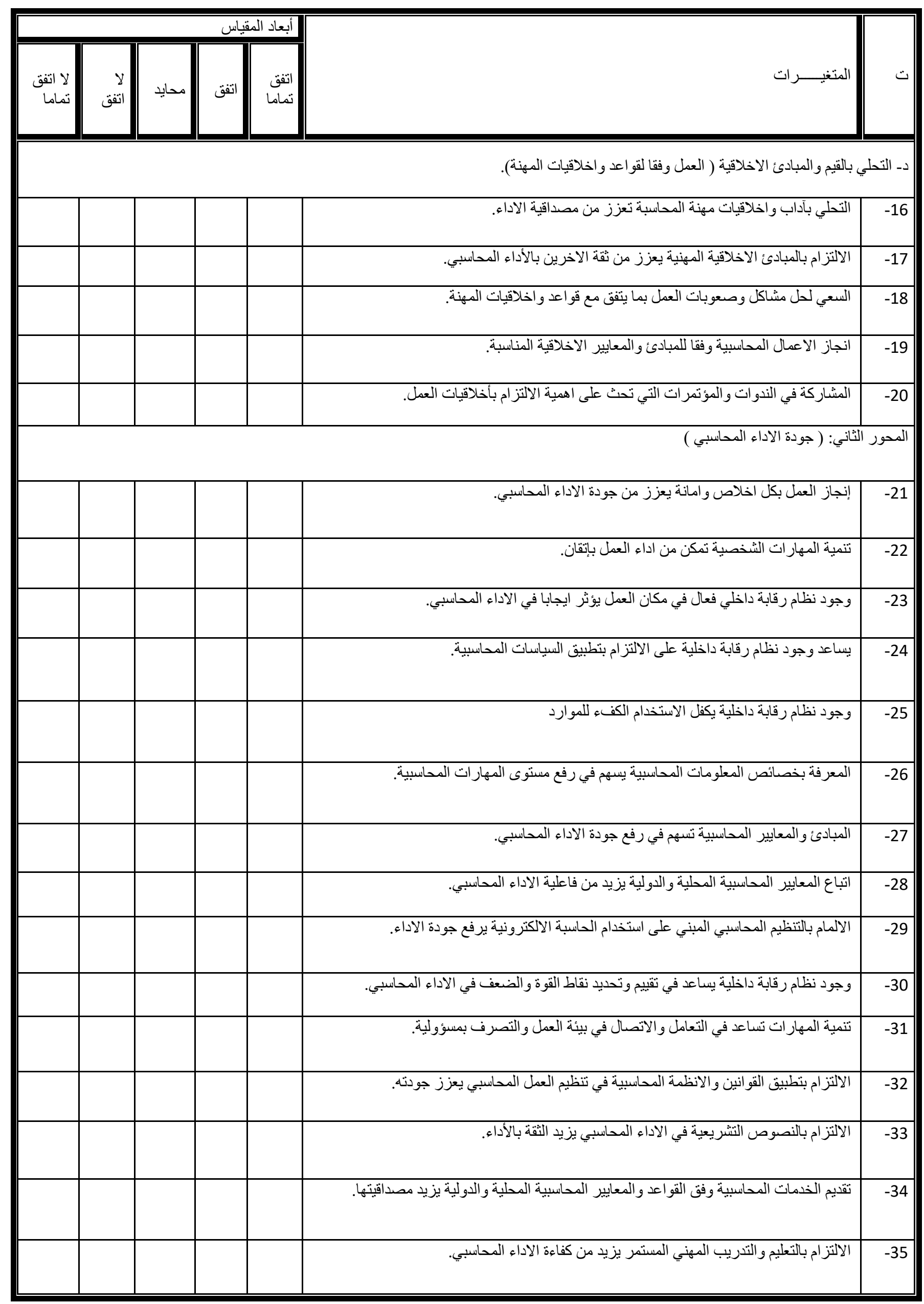




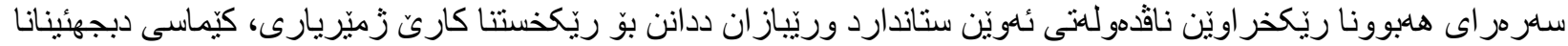

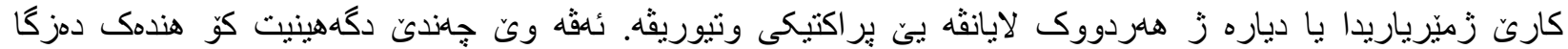

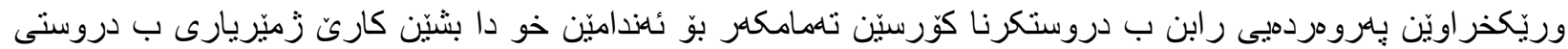

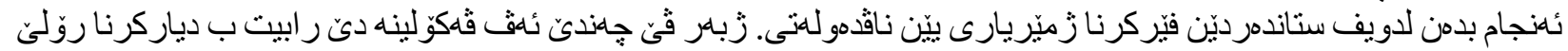

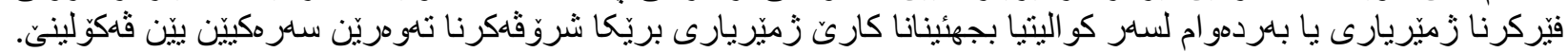

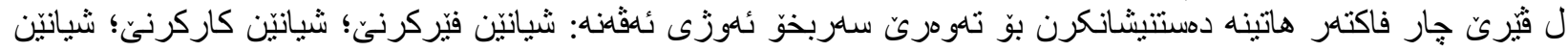

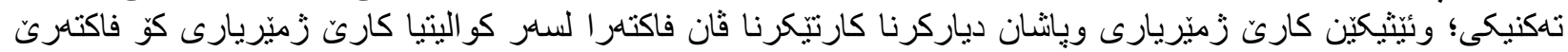

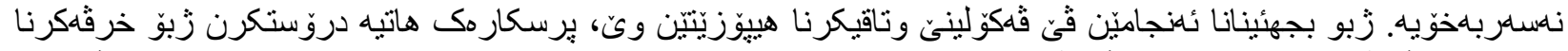

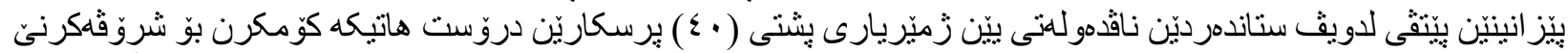

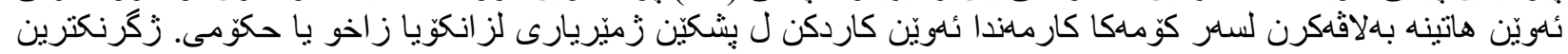

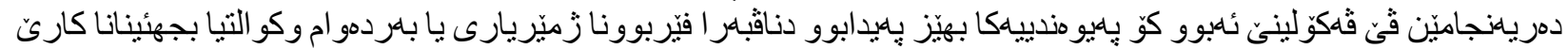

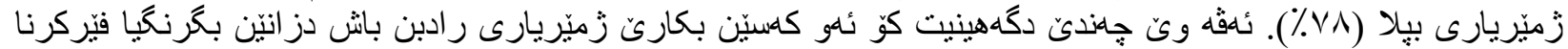

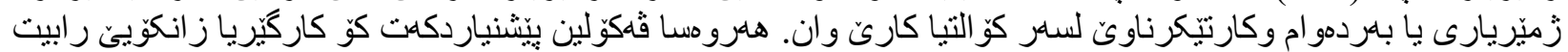

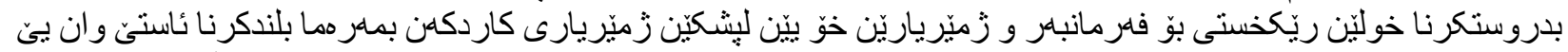

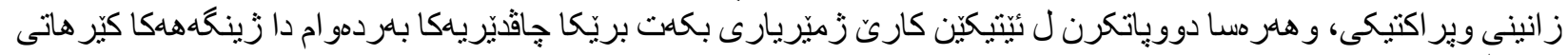

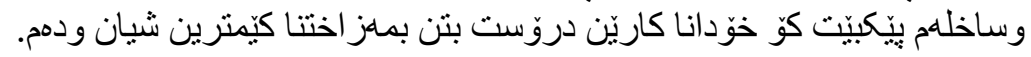

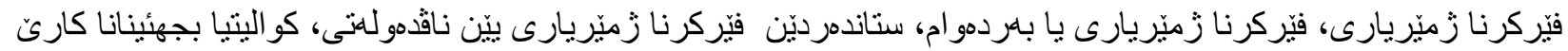

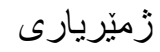

\title{
The Role of Continuous Accounting Education in Enhancing the Quality of Accounting Performance: Empirical Evidence from Accounting Departments' Employees of University of Zakho
}

\begin{abstract}
Abstruct:
Although the existence of international professional organizations that issue standards and rules to regulate the accounting profession, there is a weakness in the accounting performance in both theoretical and practical aspects, which led many educational institutions to work on raising the efficiency of accountants through adopting continuous educational programs that provide efficient accounting education requirements in accordance with international accounting education standards. This study aims to diagnose the role of continuous accounting education in enhancing the quality of accounting performance by analyzing main variables of the study. Four independent variables were selected naming cognitive skills, professional skills, technical skills, and ethics to be examined for showing their effect on the quality of accounting performance. To achieve study objectives and testing the hypotheses, a questionnaire was designed as a tool for collecting data in accordance with international accounting education standards and was analyzed according to statistical programs after collection of (40) valid questionnaires distributed to accountants in the University of Zakho. The study revealed that there is a significant correlation between continuous accounting education and the quality of accounting performance. It also showed a significant impact relationship between both main variables of the study amounted to $(78 \%)$. This means that the study sample confirms the importance of continuous accounting education and its positive impact on performance quality. The study recommends the University Management to adopt continuous training courses in order to improve accounting employees' skills as well as focusing on importance of profession's ethics under a periodic control to ensure an environment that is efficient, impartial and quick in accomplishing tasks with minimal efforts.
\end{abstract}

Keywords: Continuous Accounting, Continuous Accounting Education, international accounting education standards, Quality of Accounting Performance. 